
Natuurinclusief ondernemen: van koplopers naar mainstreaming? 
Dit Technical report is gemaakt conform het Kwaliteitshandboek van de unit Wettelijke Onderzoekstaken Natuur \& Milieu.

De reeks 'WOt-technical reports bevat onderzoeksresultaten van projecten die kennisorganisaties voor de unit Wettelijke Onderzoekstaken Natuur \& Milieu hebben uitgevoerd.

WOt-technical report $\mathbf{6 3}$ is het resultaat van een onderzoeksopdracht van het Planbureau voor de Leefomgeving (PBL). Het PBL is een inhoudelijk onafhankelijk onderzoeksinstituut op het gebied van milieu, natuur en ruimte, zoals gewaarborgd in de Aanwijzingen voor de Planbureaus, Staatscourant 3200, 21 februari 2012.

Dit onderzoeksrapport draagt bij aan de kennis die verwerkt wordt in meer beleidsgerichte publicaties zoals Natuurverkenning, Balans van de Leefomgeving en andere thematische verkenningen.

Het onderzoek is gefinancierd door het Ministerie van Economische Zaken (EZ). 


\section{Natuurinclusief ondernemen: van koplopers naar mainstreaming?}

M.J.W Smits, C.M. van der Heide, H. Dagevos, T. Selnes \& C.M. Goossen 


\section{Referaat}

Smits, M.J.W., C.M. van der Heide, H. Dagevos, T. Selnes \& C.M. Goossen (2016). Natuurinclusief ondernemen: van koplopers naar mainstreaming?. Wettelijke Onderzoekstaken Natuur \& Milieu, WOttechnical report 63.74 blz.; 16 fig.; 4 tab.; 73 ref.

In de Rijksnatuurvisie is een belangrijke rol weggelegd voor particulier initiatief in het natuurbeleid, met name voor bedrijven. Hiervoor wordt de term 'natuurinclusief ondernemen' geïntroduceerd. In de praktijk zien we daadwerkelijk steeds meer ondernemers die natuur meenemen in hun businesscase. Anderzijds zijn er ook talrijke ondernemers die deze stap (nog) niet hebben gemaakt. Om de ambitie zoals beschreven in de Rijksnatuurvisie waar te maken, is het nodig dat er een breed gedragen visie ontstaat bij bedrijven dat natuurvriendelijk ondernemerschap de toekomst heeft. Dit noemen we mainstreaming. Maar hoe realistisch is de verwachting dat een groot deel van de bedrijven deze omslag naar natuurvriendelijk ondernemen maakt de komende periode? Dit rapport geeft een reflectie op de ambities zoals beschreven in de Rijksnatuurvisie voor een transitie naar een natuurinclusieve economie, en met name de verwachtingen voor natuurinclusief handelen door ondernemers. Daarbij focussen we op enkele sectoren met veel grond, te weten de (biologische) landbouw, de recreatiesector en het particulier landgoedbezit.

Trefwoorden: Rijksnatuurvisie, natuurinclusief ondernemen, natuurvriendelijke bedrijven, marketingtheorie, transitietheorie

\section{Abstract}

Smits, M.J.W., C.M. van der Heide, H. Dagevos, T. Selnes \& C.M. Goossen (2016). Nature-inclusive business: From frontrunners to mainstream? The Statutory Research Tasks Unit for Nature and the Environment (WOT Natuur \& Milieu). WOt-technical report 63. 74 p.; 16 Figs; 4 Tabs; 73 Refs

The government vision on nature 'The Natural Way Forward: Government Vision 2014' gives an important role to private initiatives in nature conservation, particularly by businesses. The aim is to create what is called the 'nature-inclusive economy'. While a growing number of entrepreneurs are indeed bringing nature into their business case, many have not taken this step. To realise the ambition set out in the Government Vision 2014, environmentally-friendly entrepreneurship must be accepted by businesses as the shared vision of the future. This is called mainstreaming. But how realistic is the expectation that a large proportion of businesses will switch to a nature-inclusive business model in the near future? This report reflects on the ambitions set out in the Government Vision 2014 for a transition to a nature-inclusive economy, and in particular the expectation that entrepreneurs will adopt nature-inclusive activities. We focus on those sectors which own large areas of land, namely conventional and organic farming, recreation and private rural estate management.

Keywords: government vision on nature, nature-inclusive business, marketing theory, transition theory

\section{(C) 2016}

\section{LEI Wageningen UR}

Postbus 29703, 2502 LS Den Haag

Tel: (070) 33583 30; e-mail: informatie.lei@wur.nl

\section{Alterra Wageningen UR}

Postbus 47, 6700 AA Wageningen

Tel: (0317) 4807 00; e-mail: info.alterra@wur.nl

De reeks WOt-technical reports is een uitgave van de unit Wettelijke Onderzoekstaken Natuur \& Milieu, onderdeel van Wageningen UR. Dit report is verkrijgbaar bij het secretariaat. De publicatie is ook te downloaden via www.wageningenUR.nl/wotnatuurenmilieu.

Wettelijke Onderzoekstaken Natuur \& Milieu, Postbus 47, 6700 AA Wageningen Tel: (0317) 4854 71; e-mail: info.wnm@wur.nl; Internet: www.wageningenUR.nl/wotnatuurenmilieu

Alle rechten voorbehouden. Niets uit deze uitgave mag worden verveelvoudigd en/of openbaar gemaakt door middel van druk, fotokopie, microfilm of op welke andere wijze ook zonder voorafgaande schriftelijke toestemming van de uitgever. De uitgever aanvaardt geen aansprakelijkheid voor eventuele schade voortvloeiend uit het gebruik van de resultaten van dit onderzoek of de toepassing van de adviezen. 


\section{Woord vooraf}

In de periode 2012 tot en met 2014 zijn bedrijven en sectoren geanalyseerd die voorlopen wat betreft hun inzet om ecosysteemdiensten in stand te houden. In de Rijksnatuurvisie 2014 is hoog ingezet op de ambities en de rol van bedrijven bij het in stand houden van natuur en ecosysteemdiensten. Om deze ambities waar te kunnen maken, is het noodzakelijk dat de voorlopers gezelschap krijgen van de middenmoot. Hoe realistisch is het dat dit wordt gerealiseerd? Dit is de centrale vraag in het hier voor u liggende WOt-technical report. Daarbij hebben we met name gekeken naar enkele sectoren die veel grond in bezit hebben en daarmee een expliciete relatie met natuur onderhouden, namelijk (biologische) landbouw, landgoedeigenaren, en de recreatiesector.

We hebben drie interviews gehouden met vertegenwoordigers van belangenorganisaties. We willen de mensen die bereid waren tijd vrij te maken om ons te woord te staan en hun kennis en ervaring met ons te delen, nadrukkelijk bedanken voor hun bijdrage: Maaike Raaijmakers van Bionext, Ronnie van Woudenberg van de Federatie Particulier Grondbezit (FPG) en Ivo Gelsing van de Vereniging van Recreatieondernemers Nederland (RECRON).

Op het gebied van consumentenwetenschappen, transitie- en marketingtheorie zijn we bijgestaan door collega's binnen Wageningen UR: Hans Dagevos, Trond Selnes en Martin Goossen. Wij danken hen zeer voor hun medewerking.

Opdrachtgever vanuit het Planbureau voor de Leefomgeving (PBL) was Petra van Egmond. Themacoördinator vanuit de WOT Natuur \& Milieu was Frank Veeneklaas. Beiden willen we hartelijk danken voor hun constructieve bijdragen.

Namens het onderzoeksteam

Marie-José Smits en Martijn van der Heide 



\section{Inhoud}

1 Opzet onderzoek en afbakening

$\begin{array}{lll}1.1 & \text { Doelstelling onderzoek } & 11\end{array}$

1.2 Neoklassieke economie: natuur en ondernemen is een onmogelijke combinatie 13

$\begin{array}{lll}1.3 & \text { Twee denkrichtingen voor natuurinclusief ondernemen } & 14\end{array}$

$\begin{array}{ll}1.4 & \text { Afbakening } \\ \end{array}$

$2 \quad$ Theorieën over transitie en marktsegmenten $\quad 17$

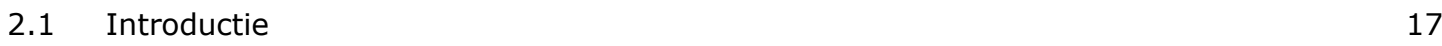

$\begin{array}{ll}2.2 \text { Marketingtheorie } & 17\end{array}$

$\begin{array}{ll}\text { 2.2.1 Dé consument bestaat niet } & 17\end{array}$

2.2.2 Eenheid in verscheidenheid: (beh)oud en nieuw 18

$\begin{array}{ll}2.2 .3 \text { Van homo economicus naar burgerconsumenten } & 21\end{array}$

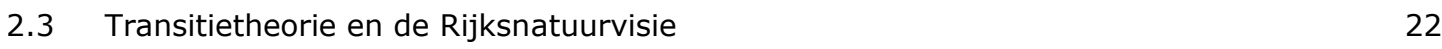

2.3.1 Inleiding $\quad 22$

2.3.2 Acht doelen voor de toekomst $\quad 24$

2.3.3 Nieuwe rollen en veranderende verhoudingen $\quad 24$

$\begin{array}{lll}2.4 & \text { Zitten we midden in een transitie? } & 26\end{array}$

$3 \quad$ Achtergrond Rijksnatuurvisie en uitwerkingen $\quad 27$

$\begin{array}{lll}3.1 & \text { Introductie } & 27\end{array}$

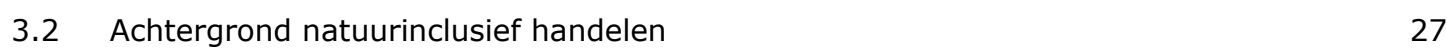

$\begin{array}{lll}3.3 & \text { Instrumenten van het beleid } & 31\end{array}$

$\begin{array}{lll}3.4 & \text { Bijdragen vanuit het bedrijfsleven } & 32\end{array}$

$\begin{array}{lll}3.5 & \text { Lessen voor dit onderzoek } & 34\end{array}$

4 Voorbeelden van natuurinclusief handelen door bedrijven $\quad 35$

$\begin{array}{lll}4.1 & \text { Introductie } & 35\end{array}$

$\begin{array}{lll}4.2 & \text { Biologische landbouw } & 35\end{array}$

$\begin{array}{lll}4.2 .1 & \text { Algemeen } & 35\end{array}$

$\begin{array}{ll}4.2 .2 \text { Bionext } & 37\end{array}$

$\begin{array}{lll}4.3 & \text { Particulier landgoedbezit } & 39\end{array}$

$\begin{array}{ll}\text { 4.3.1 Algemeen } & 39\end{array}$

4.3.2 Federatie Particulier Grondbezit $\quad 41$

$\begin{array}{lll}4.4 & \text { Recreatie in de natuur } & 43\end{array}$

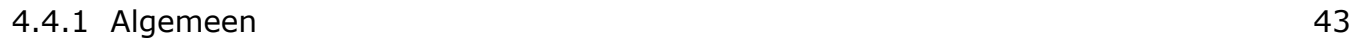

$\begin{array}{lll}4.4 .2 & \text { RECRON } & 45\end{array}$

$5 \quad$ Een uitwerking van de recreatiesector $\quad 49$

$\begin{array}{lll}5.1 & \text { Introductie } & 49\end{array}$

5.2 Manifeste vraag naar natuur in de recreatiesector $\quad 49$

5.3 Marktsegmenten $\quad 51$

5.4 Natuurbeelden $\quad 53$

5.5 Ontwikkelingen en Trends $\quad 55$

$\begin{array}{ll}5.6 & \text { Latente vraag recreatiediensten } \\ 5.7 & 56\end{array}$

$\begin{array}{lll}5.7 & \text { Omvang donkergroen en lichtgroene natuur } & 57\end{array}$

$\begin{array}{lll}5.8 \text { Conclusies } & 61\end{array}$ 
$\begin{array}{lll}6.1 & \text { Samenvatting } & 63\end{array}$

6.2 Discussielijnen $\quad 64$

$\begin{array}{lll}6.3 & \text { Ter afsluiting } & 66\end{array}$

$\begin{array}{lr}\text { Literatuur } & 67\end{array}$

Verantwoording

71 


\section{Summary}

The ambition of the government vision on nature (2014) is a nature-inclusive economy. Entrepreneurs are expected to play an important role in bringing this about, but is this a realistic expectation? We describe three mindsets:

\section{- Mindset 1}

Nature and entrepreneurship is a tricky combination. Under neoclassical economic theory it can be argued that nature is a public good and therefore that private investments should not be expected. However, as some businesses are demonstrably investing in nature, this mindset clearly does not explain everything. Therefore, two other mindsets are used.

\section{- Mindset 2}

There will be a transition to a nature-inclusive economy. The generally accepted standard will be the incorporation of nature conservation into business models. We describe this mindset as the 'transition theory'.

\section{- Mindset 3}

Nature-friendly enterprise will remain a marketing strategy and will therefore become a market segment alongside other segments. This means that some companies will adopt 'conservation of nature' into their business model and communicate this to their clients. This is in line with marketing theory.

The transition theory begins with benevolent coalitions that start to experiment and go through a learning process. This leads to initiatives and successors. At some point, there are so many initiatives that a take-off phase is achieved and a breakthrough can be forced to a new paradigm, a new way of looking at the world that in time becomes the conventional view. In this case the new paradigm will be that incorporating nature into business models is standard practice.

Marketing theory includes the analysis of consumer behaviour. Consumers come in many shapes and sizes. The consumer market is fragmented - there are many different preferences - but at the same time the picture is mixed, since consumers do not act consistently. How we act in the consumer market is highly dependent on our environment: what is available, what do others expect of us, etc. This phenomenon can be used to 'nudge' consumers in the desired direction by adjusting the environment. According to marketing theory, nature-inclusive business is a niche market, but the government can influence consumer behaviour to increase the niche.

Private initiative is not a new phenomenon in nature conservation, but the new nature vision has farreaching consequences, for example for financing. Moreover, private initiatives involving nature have different forms, some with and some without financial support from the government. The government has developed various instruments to facilitate private initiatives. The traditional government approach is hierarchical and legislative, but in recent years more attention has been given to facilitation and networking for social initiatives.

We focused on three land-owning sectors: organic farming, recreation and private rural estate management. There are large differences in the government's approach to these sectors. Government support for organic farming has been reduced over the past few decades. In recent years, though, the area under organic farming has grown, but organic farming makes up less than $5 \%$ of the Dutch agricultural sector. Organic farming is generally considered to be better for nature and the environment than conventional farming, and organic farmers are relatively more involved in more diversified agriculture and in agri-environmental schemes. In the recreation sector there has also been a trend in recent years towards incorporating nature into the recreational experience and combining economic growth with nature conservation. Consumers want more luxury, but back to nature camping and farm campsites are also becoming more popular. The traditional business model for private rural estate used to be forestry, farming and hunting. For some estates nature may become a source of additional earnings. The government has signed 'Green Deals' with both the private rural estate and recreation sectors to support local sustainable projects which are otherwise hard to realise. 
The organisations representing organic agriculture, recreation and private rural estates (BIONEXT, Recron and FPG, Dutch Federation for Private Landownership) are positive about the government vision on nature and the idea of a nature-inclusive economy. They see opportunities for entrepreneurs, but all three argue that legislation remains an obstacle to realising the ambition of the vision document. BIONEXT cite several examples of recent legislative changes which even had an adverse effect on nature, including entrepreneurship by organic farmers. Another obstacle is increased bureaucracy due to the decentralisation of nature policy, says FPG. RECRON argues that because of rigid regulations entrepreneurs are reluctant to turn over land temporarily to nature because they fear they may be locked into this use.

The possibilities for nature-inclusive entrepreneurship within the recreation sector are further elaborated. Current demand for recreation in or near nature reserves is estimated to make up nearly $10 \%$ of the market for recreation, but this can be grown by taking recreation value more into account. The recreational value of the Dutch 'big five' - deer, boar, beaver, red deer and seal - is high and attempts are being made to interest recreationists in the 'big five' and create support for nature reserves. The conclusion is that green recreation has growth potential, but remains a niche market. 


\section{$1 \quad$ Opzet onderzoek en afbakening}

\subsection{Doelstelling onderzoek}

De Rijksnatuurvisie 'Natuurlijk verder' is een strategisch document waarin op hoofdlijnen het natuurbeleid voor de komende periode wordt geschetst (EZ, 2014). In de Rijksnatuurvisie is een belangrijke rol weggelegd voor particulier initiatief in het natuurbeleid, en met name ook voor bedrijven. "Groen ondernemerschap speelt een centrale rol in de visie van het kabinet op de toekomstige natuur in ons land." (Rijksnatuurvisie, blz. 7). En: "Ondernemers zoeken naar manieren om de natuur met hun bedrijf te verweven, de zorg voor biodiversiteit en natuurlijke hulpbronnen te verankeren in hun bedrijfsstrategie en te leren van natuurlijke processen." (Rijksnatuurvisie, blz. 37).

Deze nieuwe manier van denken wordt 'natuurinclusief' genoemd. "Het woord natuurinclusief betekent letterlijk: natuur inbegrepen. Het duidt op een manier van denken en doen waarin natuur altijd wordt 'meegenomen'. Natuurinclusief denken en doen heeft twee kanten: die van de kans en die van de voorzorg. Door meer gebruik te maken van principes en eigenschappen van de natuur hebben we de kans om beter en goedkoper te werken. En door met voorzorg te werken, kunnen we schade aan natuur verminderen of zelfs voorkomen." (Rijksnatuurvisie, blz. 19). Het streven van de minister is een 'natuurinclusieve economie'.

De alledaagse praktijk laat inderdaad een toenemend aantal initiatieven van bedrijven zien waarbij natuur een rol speelt. Zo zien steeds meer ondernemingen natuur en biodiversiteit als mogelijkheid zich te profileren op consumentenmarkten. Tegelijkertijd echter zijn er ook tal van bedrijven die deze stap (nog) niet gemaakt hebben (Dirkx en De Knegt, 2014, blz. 6). Om de ambitie zoals beschreven in de Rijksnatuurvisie waar te maken, is het nodig dat er een breed gedragen visie ontstaat bij bedrijven dat natuurvriendelijk ondernemerschap de toekomst heeft. Dit noemen we mainstreaming. Maar hoe realistisch is de verwachting dat een groot deel van de bedrijven deze omslag naar natuurvriendelijke productie maakt de komende periode?

Doel van het project is een reflectie op de ambities zoals beschreven in de Rijksnatuurvisie voor een transitie naar een natuurinclusieve economie, en met name de verwachtingen voor natuurinclusief handelen door ondernemers.

\section{De begrippen 'transitie' en 'natuurinclusief' in de Rijksnatuurvisie}

In een tweetal figuren worden in de Rijksnatuurvisie de taken en doelen van de Rijksoverheid voor het natuurbeleid voor de komende periode samengevat.

In figuur 1.1, waarin de taken van de overheid worden samengevat, wordt bij Bouwwerk twee maal het begrip transitie gebruikt: Het Rijk heeft de ambitie de maatschappelijke transities naar duurzaamheid te stimuleren, en: Het Rijk neemt belemmeringen voor transitie weg. Het begrip 'transitie' veronderstelt nogal wat. "Een transitie is een structurele maatschappelijke verandering die het resultaat is van op elkaar inwerkende en elkaar versterkende ontwikkelingen op het gebied van economie, cultuur, technologie, instituties en natuur en milieu." (Rotmans, 2003, blz. 14).

Op welke transitie doelt men in figuur 1.1? Dit is niet expliciet terug te vinden in de tekst, maar wel impliciet. Het Rijk wil aansluiten bij maatschappelijke ontwikkelingen, en stelt dat het initiatief ligt bij de 'energieke samenleving'. Vanuit die samenleving ziet men steeds meer initiatieven van burgers en bedrijven die zich inzetten voor een gezonde leefomgeving en duurzaam gebruik van natuurlijke hulpbronnen om zo de maatschappelijke en economische waarde van natuur te vergroten (Rijksnatuurvisie, blz. 36). Dit krijgt vorm in groen ondernemerschap, natuurinclusieve landbouw, gebiedsontwikkeling met natuurcombinaties en groen wonen en werken (zie figuur 1.2). Onder transitie wordt dus een maatschappelijke transitie verstaan, zoals in figuur 1.1 aangegeven, en dit heeft als gevolg een andere rol voor de overheid. 


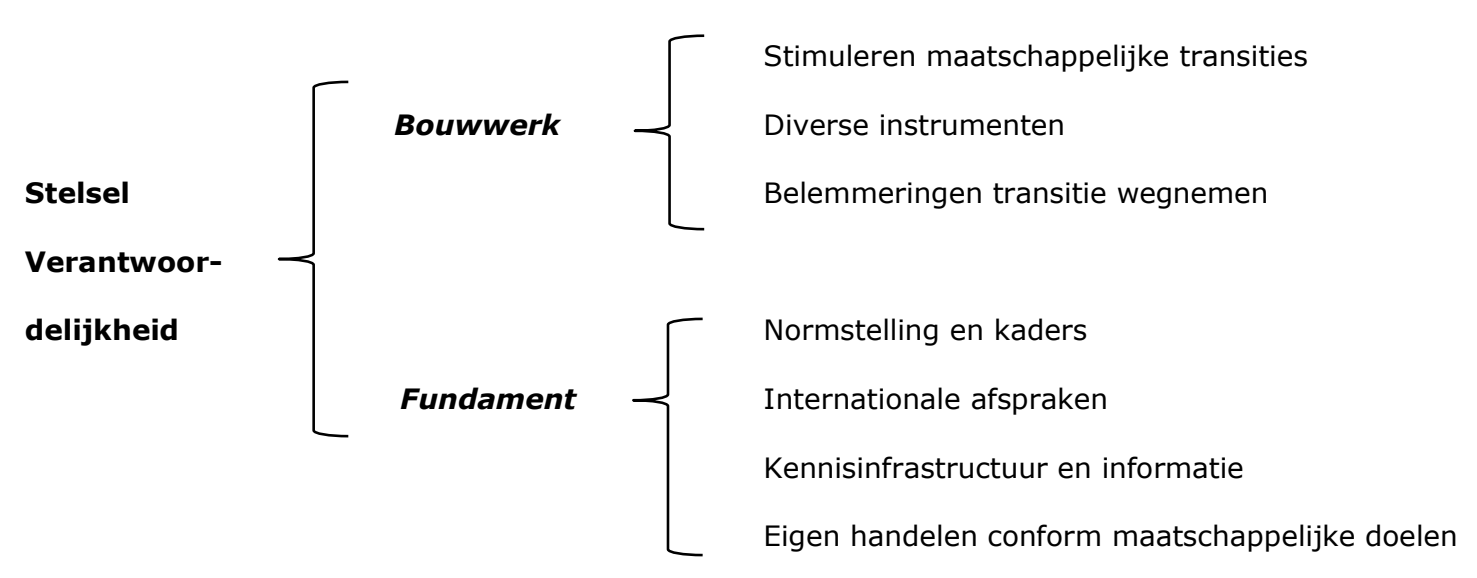

Figuur 1.1: De taken van de overheid ten aanzien van natuurbeleid (zie Rijksnatuurvisie, blz. 36)

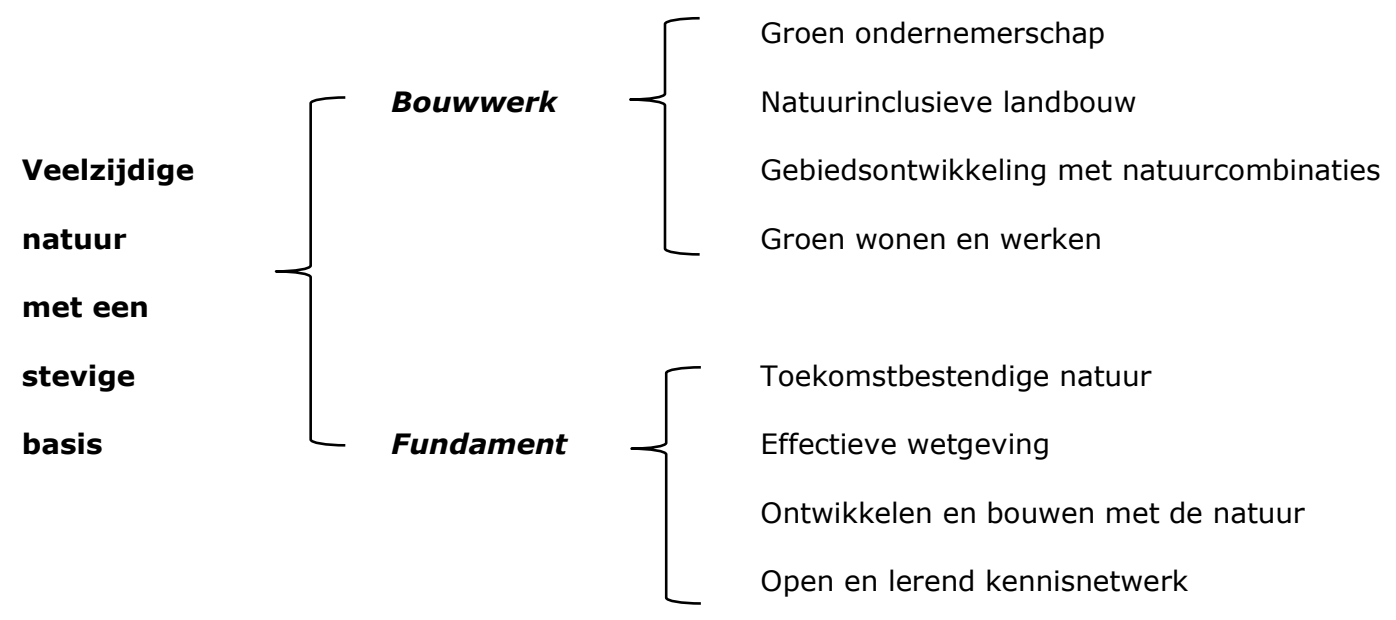

Figuur 1.2: De doelen van de overheid ten aanzien van natuurbeleid (zie Rijksnatuurvisie, blz. 37; $E Z, 2014$ )

Het streefbeeld is een natuurinclusieve economie. Natuurinclusief is: rekening houdend met de natuur. De overgang van de huidige maatschappij naar dit streefbeeld noemen we transitie. Deze overgang kan, wat betreft het bedrijfsleven, bewerkstelligd worden door mainstreaming: de visie van enkele koplopers voor natuurvriendelijk ondernemen wordt overgedragen op een grote groep ondernemers zodat deze visie algemeen geldend wordt. Mainstreaming kan op verschillende manieren: door het kopiëren van bedrijfsstrategieën van koplopers, door (regionale) samenwerkingsverbanden aan te gaan, of door nieuwe niches te bezetten.

Met natuurinclusief handelen bedoelen we nadrukkelijk bovenwettelijk handelen ten voordele van de natuur, dus: meer doen dan de wet vraagt om natuurbehoud en natuurontwikkeling te bevorderen. Dit staat niet expliciet in de Rijksnatuurvisie, maar ons inziens wel impliciet. In 'het fundament' van figuur 1.1 en 1.2 komen wetgeving, normstelling en kaders ter sprake; 'het bouwwerk' lijkt meer dan dat te omvatten, namelijk particulier initiatief bovenop de wetgeving.

Het idee dat vanuit de samenleving zinvolle initiatieven ontplooid worden, en dat de overheid daar ruimte voor moet scheppen en daarom een stapje terug moet doen, past binnen de visie van een 'participatiemaatschappij'. In de troonrede van 2013 werd het begrip 'participatiesamenleving' gebruikt als alternatief voor de verzorgingsstaat. 


\subsection{Neoklassieke economie: natuur en ondernemen is een onmogelijke combinatie}

Natuurinclusief ondernemen laat zich lastig beschrijven vanuit de neoklassieke economische theorie. In de neoklassieke economie gaat men ervan uit dat natuur en ondernemen een onmogelijke combinatie is, omdat natuur een publiek goed is. Publieke goederen worden in de economische theorie gedefinieerd als goederen die niet-uitsluitbaar en niet-rivaliserend zijn. Niet-uitsluitbaar wil zeggen: iedereen kan ervan genieten, omdat je niemand kunt buitensluiten. Niet-rivaliserend betekent: wanneer de ene persoon ervan geniet dan kan tegelijkertijd een andere persoon er ook van genieten. Niet-uitsluitbaar is een belangrijk kenmerk van publieke goederen omdat voor deze goederen het freerider probleem geldt, dat wil zeggen, je kunt er lastig een bijdrage voor vragen omdat mensen het ook gratis kunnen krijgen. Niet-rivaliserend is een belangrijk kenmerk omdat op een private markt voor deze diensten onderconsumptie ontstaat, een niet-optimale situatie dus. Natuur is niet-uitsluitbaar, tenzij je er een hek omheen zet - letterlijk of figuurlijk - en entree gaat heffen (zie bijv. de Amsterdamse waterleidingduinen). En natuur is niet-rivaliserend omdat je met meerdere personen er tegelijkertijd van kunt genieten (tenzij het op een mooie zondagmiddag zo druk wordt in een natuurgebied dat dit ten koste gaat van het genieten).

Omdat natuur de eigenschappen heeft van een publiek goed, kan het niet met winst worden geproduceerd door private bedrijven. Maar hier is nuancering op zijn plaats, want natuur levert ook producten die wel via de markt verhandeld kunnen worden, zoals voedsel (wildbraad), biomassa, drinkwater en versieringen (kersttakken, bloemen etc.). Dergelijke groene producten laten zien dat sommige onderdelen van de natuur eigenschappen van een privaat goed hebben. En als we privaat en publiek als de twee uiterste van een spectrum zien, dan zijn er ook voorbeelden te bedenken van natuur als deels privaat en deel publiek. Denk aan visgronden of bossen: deze zijn doorgaans voor iedereen toegankelijk (niet-uitsluitbaar), maar het kappen van bomen door een consument betekent dat er minder bomen overblijven voor andere houtkappers (er is dus sprake van rivaliteit). Hetzelfde geldt voor visgronden. Zulke 'niet-zuivere publieke goederen' noem je gemeenschapsgoederen (ook wel: common pool resources).

Een andere vorm van niet-zuivere publieke goederen zijn clubgoederen. Deze goederen zijn nietrivaliserend (het gebruik door de een gaat niet ten koste van het gebruik door een ander), maar individuen kunnen wel van gebruik worden uitgesloten. Daardoor zijn de baten van deze goederen exclusief (vergelijkbaar met de baten van een privaat goed). Natuurterreinen in handen van Staatsbosbeheer of Natuurmonumenten kunnen als clubgoederen worden beschouwd. In principe kunnen deze terreinbeherende organisaties er een hek omheen zetten en mensen uitsluiten van het gebruik ervan. Pas als je lid bent van de terreinbeherende organisatie, of entree betaalt aan een toegangspoort, maak je onderdeel uit van de club en kun je van de natuur genieten.

Ook al wordt natuur vaak als een zaak van publiek belang beschouwd, toch laat de praktijk zien dat er bedrijven zijn die investeren in natuur (zie voor voorbeelden: Breman et al., 2014; Wilschut en Koedoot, 2014; Fontein et al., 2015). Natuurlijk, niet alle natuur kan direct worden vermarkt - er zijn bijvoorbeeld maar weinig natuurgebieden waar entree geheven wordt - maar zoals hierboven aangegeven zijn er producten uit diezelfde natuur die wél via markten worden verhandeld.

Tegelijkertijd komt het belang van natuur indirect in (de prijzen van) private goederen en diensten tot uitdrukking, bijvoorbeeld via het imago van een bedrijf, als decor voor een recreatieondernemer of als inspiratiebron voor innovatie (zoals biomimicry). Daarnaast zijn er financiële regelingen van de overheid, zoals de subsidieregeling Biodiversiteit en Bedrijven (zie Schuerhoff en Ruijs, 2015) en de subsidieregeling voor particuliere natuurbeheerders (Subsidie Natuur- en Landschapsbeheer, SNL).

De opvatting dat natuur en ondernemen niet te combineren zijn, is een onhoudbare ontkenning van de dagelijkse werkelijkheid. Daarom gaan we in paragraaf 1.3 verder met twee andere denkrichtingen. 


\subsection{Twee denkrichtingen voor natuurinclusief ondernemen}

We gebruiken twee denkrichtingen om natuurinclusief ondernemen te beschrijven en te verklaren. Allereerst het idee dat groen ondernemerschap en natuurinclusief handelen de toekomst zijn en op termijn mainstream zullen worden. De transitie naar een natuurinclusieve maatschappij kunnen we dan geslaagd noemen. En anderzijds het idee dat er verschillende marktsegmenten zijn, waarbij 'groen' een marktsegment is naast andere segmenten. Dit verondersteld dat 'groen' niet mainstream wordt, maar een bepaald percentage van de markt blijft vormen. Dit segment kun je koplopers noemen wat betreft groen ondernemerschap, met dien verstande dat zij koplopers zullen blijven en geen aansluiting zullen krijgen van het peloton.

De doelstelling van het project, een reflectie op de ambities voor natuurinclusief handelen door ondernemers, wordt verder ingevuld aan de hand van de volgende vragen: Kloppen de hierboven beschreven twee denkrichtingen, of behoeft het nuancering? Hoe verhoudt mainstreaming zich tot diversificatie van de markt? Wat zijn de consequenties hiervan voor de ambities zoals beschreven in de Rijksnatuurvisie?

\section{Eerste denkrichting: een transitie}

Om een beeld te krijgen van hoe een transitie eruit zou kunnen zien, kijken we naar de transitietheorie. Figuur 1.3 geeft schematisch weer hoe zo'n transitie naar een nieuwe maatschappelijke orde in de loop van de tijd vorm kan krijgen. Dit is een sterk vereenvoudigde voorstelling van zaken. (In hoofdstuk 2 wordt dit beeld genuanceerd en wordt de context beschreven.)

Er worden vier fasen onderkent in figuur 1.3. In de vierde fase, genaamd stabilisatie, wordt een evenwicht bereikt. Dit evenwicht houdt in: een maatschappij waarin natuurinclusief handelen door ondernemers 'mainstream' is. Mainstream hoeft overigens niet in te houden dat de meerderheid van de ondernemers kiest voor natuurinclusief ondernemen, wel dat natuurinclusief ondernemen de norm is geworden, dat wil zeggen dat ondernemers vinden dat het zo hoort, dat het loont, of het moet (zie ook Van Luijk, 2000 en Breman et al., 2014; in hoofdstuk 3 komen we hierop terug).

\section{Indicator(en) voor maatschappelijke ontwikkeling}

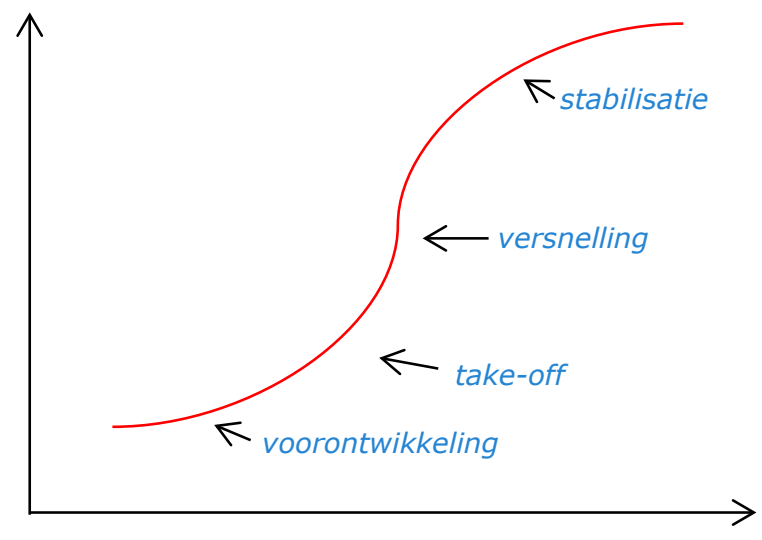

Figuur 1.3: Een eenvoudig fasemodel van het transitieproces. Bron: Rotmans et al., 2000, blz. 23.

\section{Tweede denkrichting: onderverdeling in marktsegmenten}

De tweede denkrichting is afkomstig uit de marketingtheorie. Het idee is dat een markt onderverdeeld kan worden in verschillende segmenten, bijvoorbeeld het marktsegment 'groen', naast 'goedkoop', 'luxe', 'gemak' en 'traditioneel' (figuur 1.4). De impliciete verwachting is dat natuurinclusief handelen door bedrijven een marktsegment is, met een bepaald aandeel. Dit aandeel kan groeien, maar de verwachting is niet dat 'groen' automatisch de nieuwe maatschappelijke werkelijkheid wordt.

In figuur 1.4 ziet dat er als volgt uit (de hoogte van de kolommen zijn willekeurig): 


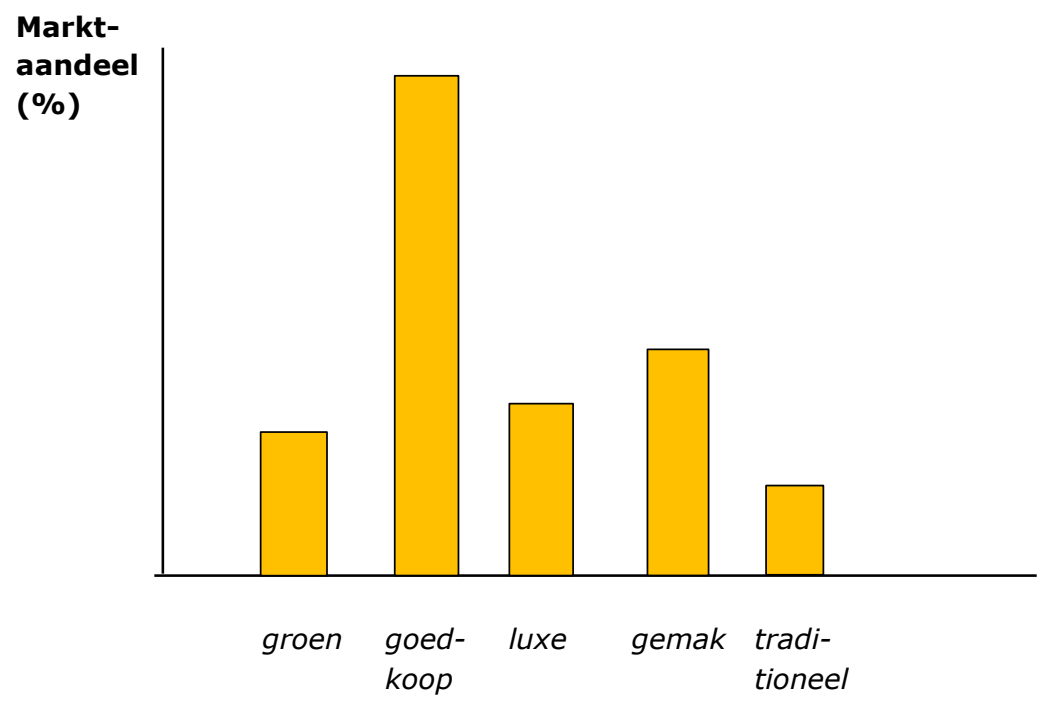

Marktsegmenten

Figuur 1.4: Marktsegmenten

Ook dit is een vereenvoudigde weergave van de werkelijkheid. (En ook hiervan geven we in hoofdstuk 2 een nuancering.) Vaak komen combinaties voor: door de week eten we gemakkelijk, maar in het weekend eten we luxe. Of: we kiezen voor de beste kwaliteit, en daarom voor zowel groen als luxe. Een combinatie van de twee denkrichtingen is ook mogelijk. Bijvoorbeeld een transitie naar een meer duurzame maatschappij bewerkstelligen door het marktsegment 'groen' te stimuleren. (Loeber en Joustra, 2004, met verwijzing naar het NIDO-programma 'Marktkansen voor Duurzame Producten').

\subsection{Afbakening}

De Rijksnatuurvisie is gericht op bedrijven én burgers. Wij richten ons in eerste instantie op bedrijven en borduren daarbij voort op voorgaand werk (Smits et al., 2013; Smits en Van der Heide, 2014). Deze focus wil niet zeggen dat consumenten buiten beeld blijven. Zij zijn voor dit onderzoek van belang omdat zij de consumenten c.q. klanten vormen voor de betreffende bedrijven, en hun opvattingen en voorkeuren het gedrag van de bedrijven daarmee direct beïnvloeden.

We richten ons op de landbouwsector, de recreatiesector en particuliere landgoedbezit. Deze sectoren hebben relatief veel grond in bezit (of in pacht) en hun handelen heeft daardoor veel impact op natuur. De voorbeelden van natuurinclusief ondernemen die genoemd worden in de Rijksnatuurvisie, komen dan ook met name uit deze grondgebonden sectoren. Bezien vanuit figuur 1.2 betekent dit dat we ons met name richten op: groen ondernemerschap, natuurinclusieve landbouw, en gebiedsontwikkeling met natuurcombinaties voor zover landbouw, recreatie en landgoederen hierin een grote rol spelen. Voor andere voorbeelden van bijdragen van ondernemers aan natuur (ook buiten de landbouw, het particuliere landgoedbezit en de recreatiesector) verwijzen we naar Kamerbeek (2012), Breman et al. (2014); Wilschut en Koedoot (2014), Fontein et al. (2015) en Kamerbeek (2015). 



\section{Theorieën over transitie en marktsegmenten}

\section{$2.1 \quad$ Introductie}

In hoofdstuk 1 hebben we een tweetal uitgangspunten beschreven, gestoeld op de marketingtheorie en op de transitietheorie. Hieronder wordt dieper op beide theorieën ingegaan, bezien vanuit de context van de Rijksnatuurvisie. Dat levert een meer genuanceerd beeld op dan de figuren 1.3 en 1.4 . We sluiten dit hoofdstuk af met een discussie over de vraag of we nu wel of niet in een maatschappelijke transitie zitten, waarin 'van onderop' een nieuwe maatschappelijke ordening tot stand komt die drijft op sociaal ondernemerschap en burgerinitiatieven.

\subsection{Marketingtheorie ${ }^{1}$}

\subsubsection{Dé consument bestaat niet}

Nederlanders zijn er in vele soorten en maten, en daarmee geldt dit evengoed voor hedendaagse consumenten. De geïndividualiseerde consument van vandaag gaat zappend en surfend door het leven. Uiteenlopende levenswegen worden voor kortere of langere tijd gevolgd; consumptiepatronen zijn allesbehalve eenduidig of altijd logisch-consistent. Heden ten dage willen en moeten mensen hun pad niet alleen zelf uitstippelen, hun sociale positie en identiteit wordt in belangrijke mate bepaald door je doen en laten in het consumptieproces, terwijl dat in het verleden eerst en vooral afhing van je positie in het productieproces. En terwijl het arbeidzame leven aan belang inboet op iemands 'zijn', wint het levensmotto 'ik consumeer, dus ik ben' aan realiteitszin. Daar komt bij dat een dergelijke individualisering bekrachtigd en bevorderd wordt door groeiende welvaart en stijgend productaanbod. Het assortiment en de variëteit in verkooppunten en -kanalen is geëxplodeerd in minder dan een halve eeuw tijd. Fysieke en economische omgevingsfactoren vormen belangrijke randvoorwaarden en zijn medebepalend voor de consumptieve keuzes die mensen maken. Omgevingsfactoren van sociaalculturele aard zijn evenzeer van invloed op wat mensen wel of niet willen. Hier gaat het om wat in reclames wordt aangeprezen, wat de heersende sociale normen zijn over wat geoorloofd is of nastrevenswaardig; over wat wordt goed- of afgekeurd, dan wel wat status geeft of juist passé of ordinair is, e.d.

De hedendaagse consument fladdert even vluchtig als veelvuldig van het een naar het andere (van plofkip naar EKO-ei, van Whopper naar Wagyu-steak, van Action en Big Bazar naar Bijenkorf). Voedingsconsumenten kunnen dan ook moeilijk eenzijdig geportretteerd worden als prijspakkers of calorieënverslinders, als gemaksconsumenten of louter gefocust op gezondheid, noch zijn ze uitsluitend geïnteresseerd in variatie. Soms willen ze achteloos eten zonder te willen weten, op het volgende moment ontpoppen ze zich tot kritische culinaire connaisseurs. Afhankelijk van het moment, de gemoedsgesteldheid, de situatie, de beschikbare hoeveelheid tijd of geld, worden uiteenlopende keuzes gemaakt die moeiteloos gecombineerd en afgewisseld worden. Ter illustratie hoeven we maar te denken aan de consument die bijvoorbeeld wel diervriendelijke kipfilet wil, maar dergelijke overwegingen geen rol laat spelen als bijvoorbeeld rundvlees wordt gekocht; aan een consument die het belangrijk vindt om biologische groenten te kopen, terwijl dit motief verdwijnt als het bijvoorbeeld om kaas gaat. De prijs van levensmiddelen is evenmin altijd doorslaggevend. De stereotype prijsbewuste consument laat zich bijvoorbeeld de dure kant-en-klaarmaaltijden of luxe toetjes goed smaken of betaalt in een restaurant zonder mokken de prijs van een pak koffie voor een kopje espresso.

\footnotetext{
${ }^{1}$ Deze paragraaf is mede gebaseerd op De Bakker en Dagevos (2010): 87-101; zie ook Dagevos en De Bakker, 2008.
} 
De wispelturige levenswandel van de geïndividualiseerde, mondige, zelfbewuste en naar zichzelf zoekende consumenten van heden ten dage, verhoudt zich dus nogal problematisch tot het idee van de consument als een enkelvoudig figuur met een eendimensionaal profiel. De reactie die hierop is gekomen, is dat consumenten in meer of mindere mate meerduidige wezens zijn die potentieel vele rollen kunnen spelen en invulling geven aan pluriforme consumptiestijlen Ze laten zich dus slecht portretteren in één kleur of met één profiel. Bijkomstige complicatie is dat die meerkoppige consument zich steeds slechter laat vangen in de netten van de klassieke verklarende variabelen als inkomen, geslacht, opleidingsniveau of leeftijd. Om dit te helpen ondervangen worden sociaalculturele aspecten aan de analyses toegevoegd: leefstijlkenmerken van consumenten of hun visie op het leven, worden dan als grondslag voor het begrijpen van hun doen en laten opgevoerd.

\subsubsection{Eenheid in verscheidenheid: (beh)oud en nieuw}

Om enige eenheid in de verscheidenheid van consumenten aan te brengen, worden indelingscriteria geformuleerd om consumenten meer groepsgewijs in beeld te krijgen. Belangrijke uniformerende dimensies die zijn aan te treffen in de literatuur op basis waarvan groepen consumenten van elkaar worden onderscheiden zijn variatiebehoefte en behoudzucht, of de dimensie eigen- en collectief belang.

In de segmenteringsmodellen van marktonderzoeksbureaus zijn het bekende onderliggende dimensies, als we kijken naar het WIN-model van TNS NIPO (waarbij WIN staat voor Waarden In Nederland) of het Mentality ${ }^{\mathrm{TM}}$-model van Motivaction. De acht consumentengroepen die in beide gevallen worden onderscheiden zijn mede gebaseerd op de mate waarin mensen vasthouden aan het vertrouwde respectievelijk gekenmerkt worden door veranderingslust. De bijbehorende benamingen spreken voor zich: behoudenden, luxezoekers en genieters vormen categorieën in het WIN-model, en in het Mentality-model figureren enerzijds de traditionele burgerij en anderzijds de postmaterialisten en de postmoderne hedonisten. In Tekstbox 1 worden de verschillende WIN-categorieën gekoppeld aan hun voorkeur voor diverse landschapstypen.

\section{Tekstbox 1:}

Verdeling (\%) van WIN-categorieën naar bezoek aan diverse landschapstypen (in 2007).

\begin{tabular}{lrrrrr}
$\begin{array}{l}\text { Segment (tussen } \\
\text { haakjes aandeel in } \\
\text { Nederland) }\end{array}$ & Bossen & Natur & Agrarisch & $\begin{array}{r}\text { Recreatie- } \\
\text { gebied }\end{array}$ & $\begin{array}{r}\text { Water- } \\
\text { gebied }\end{array}$ \\
Zorgzamen (15\%) & 15,0 & 18,0 & 18,7 & 15,1 & 9,4 \\
\hline Behoudenden (16\%) & 16,1 & 14,9 & 15,9 & 12,9 & 18,9 \\
\hline Genieters (11\%) & 10,7 & 9,0 & 8,4 & 13,4 & 12,3 \\
\hline Evenwichtigen (22\%) & 21,0 & 20,6 & 20,9 & 22,0 & 18,2 \\
\hline Luxezoekers (11\%) & 8,5 & 7,8 & 6,6 & 10,5 & 14,1 \\
\hline Zakelijken (8\%) & 6,3 & 5,2 & 4,7 & 6,9 & 8,3 \\
\hline Ruimdenkers (7\%) & 6,8 & 8,3 & 9,1 & 7,2 & 8,3 \\
\hline Geëngageerden (11\%) & 15,5 & 16,2 & 15,8 & 12,1 & 10,4 \\
\hline Totaal & 100,0 & 100,0 & 100,0 & 100,0 & 100,0 \\
\hline
\end{tabular}

Bron: Goossen, 2009

Bovenstaande tabel laat een verschil zien tussen de WIN-segmenten en het bezoek aan diverse typen gebieden. Bos- en natuurgebieden worden vooral bezocht door de Evenwichtigen, Zorgzamen, Geëngageerden en Behoudenden waarbij het aandeel Geëngageerden hoger is dan hun landelijke aandeel. Dit komt overeen met de beschrijving van dit marktsegment waarin staat vermeld dat ze geïnteresseerd zijn in kunst, natuur en politiek. Zorgzamen en Ruimdenkers trekken iets meer, en Behoudenden en Genieters trekken iets minder de natuur in dan hun landelijke aandeel. Luxezoekers en Zakelijken zijn minder in bos- en natuurgebieden te vinden, ook in relatie tot hun landelijke aandeel. Uit onderzoek blijkt tevens dat zowel persoonlijke verbondenheid met natuur in de omgeving als bereidheid tot betalen voor natuur met sterkst naar voren komen bij de 'ruimdenkers' en 'geëngageerden'. Het zwakst scoorden 'luxezoekers' en 'genieters' (De Boer et al., 2014). 
In de (wetenschappelijke) literatuur komen we vergelijkbare dimensies tegen van mensen die vasthouden aan het vertrouwde, respectievelijk gekenmerkt worden door veranderingslust (zie bijvoorbeeld Schwartz, 1992; Lewis en Bridger, 2000). De tweedeling tussen oude en nieuwe consumenten krijgt inhoud doordat de eersten zich bovenal comfortabel voelen in de status quo, zich graag conformeren en zich met genoegen overgeven aan de macht der gewoonte (neofobie), terwijl de laatsten eerder zoeken naar de schok van het nieuwe, het experiment niet schuwen en met graagte nieuwe wegen inslaan en afwijken van gebaande paden (neofilie).

Het dimensie van behoudzucht tot veranderingsdrift speelt eveneens een hoofdrol in de beroemde diffusietheorie van Everett Rogers uit het begin van de jaren zestig (Rogers, 1962). Deze dimensie ligt ten grondslag aan de welbekende consumententypologieën die Rogers onderscheidde als het gaat om de acceptatie en verspreiding van innovaties. Om te beginnen zijn er de groepen van innovatoren (innovators) en de vroege aanvaarders (early adopters). De eerstgenoemden vormen de avant garde. Het betreft een kleine groep van enkele procenten van de consumentenpopulatie. Early adopters, op hun beurt, zijn zogezegd 'dedicated followers of fashion' en vormen een grotere groep (boven de $10 \%)$. Hierna volgt de vroege meerderheid (early majority), die zodra deze overstag zijn een verandering vaak voldoende kritische massa geven, want dit segment is goed voor ruim een derde van de populatie. Hierna komt de meer sceptische late meerderheid (late majority), die gezamenlijk ook goed zijn voor een derde van de consumentenmarkt. En de rij wordt gesloten door de achterblijvers (laggards), die niet gemakkelijk noviteiten aanvaarden en samen zo rond de $15 \%$ van de consumenten representeren (zie Van Raaij en Antonides, 1997: 369-375).

De overgang van early adopters naar early majority is een hele opgave die niet altijd lukt. In de literatuur wordt gesproken over de 'kloof' tussen deze twee innovatiemomenten (zie figuur 2.1). Een nieuw idee, product of dienst wordt massa wanneer het zogenaamde 'chasm' of kloof overbrugd wordt. Dit punt ligt volgens Moore (1995) tussen de Early Adopters en Early Majority fase. Volgens Moore zijn de Innovators en Early Adopters ambassadeurs die zorgen dat de massamarkt wordt bereikt. Zij zorgen dat de kloof tussen niche- en massamarkt wordt overbrugd. Zij verspreiden een idee, product of dienst zonder extra tegenprestatie, omdat zij geloven waar het product of dienst voor staat. De early majority is een relatief grotere groep die pas toehapt als het gaat om een bewezen product of dienst met een duidelijke meerwaarde. Zolang die meerwaarde niet wordt aangetoond, blijft de kloof bestaan. De waarde die aan natuur wordt gegeven is echter verschillend, zoals blijkt uit de natuurbeelden. Het is dan ook de vraag of de kloof overbrugd kan worden.

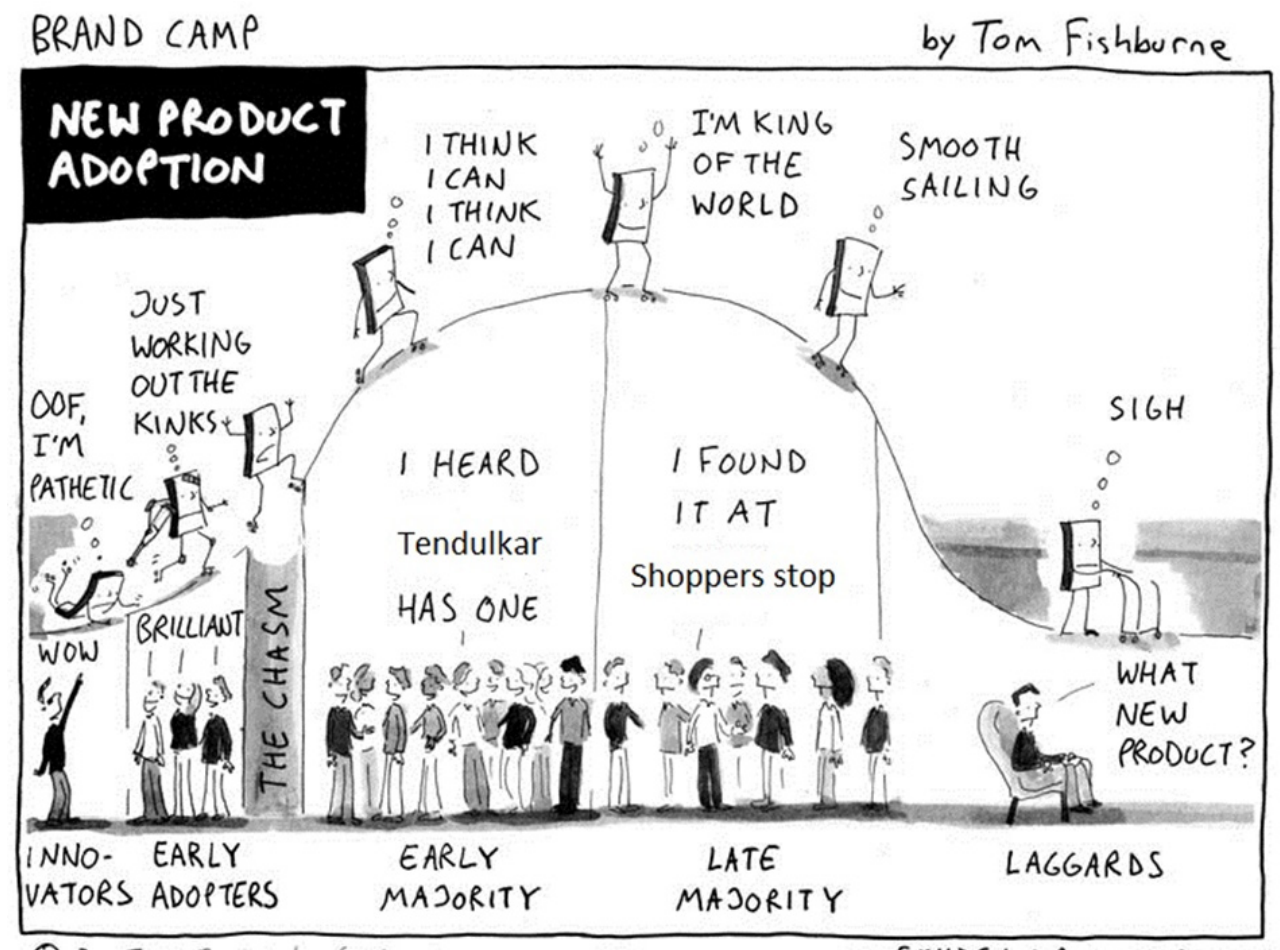

(c) 2007 Thanks to 6. Moore SKYDECKCARTOONS. COM

Figuur 2.1: De kloof tussen early adopters en early majority. 
Hoewel de gemaakte generalisaties Rogers' theorie kwetsbaar maken voor kritiek, spreken de consumentenportretten tot de verbeelding en zijn ze goed herkenbaar. Ze worden daarom nog steeds gebruikt om aan te geven dat consumenten aanzienlijk van elkaar verschillen in de mate en snelheid waarin ze een innovatie of (culturele) verandering aanvaarden. De consumentenprofielen van de innovators en de early adopters zijn in veel gevallen de belangrijkste doelwitten van trendwatchers, -spotters of -analisten. De zoektocht naar het nieuwe, naar toekomstige wensen en behoeften van mensen, wordt afgeleid van het consumptieve gedrag van voorlopers in nichemarkten of in bepaalde (underground) circuits, scenes, en dergelijke. Dit zijn per definitie geen oorden waar zich grote groepen ophouden. Wanneer de focus te eenzijdig op verandering en vernieuwing ligt, dan wordt gemakkelijk uit het oog verloren dat er hele volksstammen zijn die liever worden aangesproken op 'de goede oude tijd', op het bewaren en bewaken van wat vertrouwd is en overeenstemt met gevestigde tradities en gewoontes.

De indeling van Rogers roept ook herkenning op. Zo heeft onderzoeksbureau SAMR (samenvoeging van SmartAgent en Market Response) een segmentering gemaakt naar duurzame consumenten waarbij de diffusietheorie min of meer is terug te vinden. ${ }^{2}$

Daarbij wordt een onderscheid gemaakt tussen:

- Transformers (10\%): Duurzaamheid is erg belangrijk voor Transformers. Ze zijn hier zelf ook actief mee bezig. Ze vinden dat de overheid en bedrijven nog veel meer moeten doen. Huidige initiatieven vinden ze een druppel op een gloeiende plaat. Transformers zijn extravert, enthousiast en zien kansen. Veel jonge stellen behoren tot deze groep.

- Beacons (12\%): Beacons zijn serieus bezig met duurzaamheid en hebben veel kennis. Ze vinden het belangrijk dat bedrijven en overheden een MVO-beleid hebben om de kwaliteit van leven voor volgende generaties te behouden. Beacons zijn minder bevlogen dan Transformers. Ze handelen meer op basis van feiten en cijfers. Hun inkomen is relatief hoog, omdat ze op de top van hun carrière zitten.

- Likers (38\%): Likers zijn pro-duurzaam, maar hebben een laag kennisniveau. Duurzaamheid is iets dat je gewoon moet doen, vinden zij. Bedrijven en de overheid mogen best adviseren, maar het moet vooral gemakkelijk gemaakt worden. Als duurzaamheid geld oplevert, is dit zeker een pro. Likers zijn heel sociaal en doen vrijwilligerswerk. Vrouwen zijn oververtegenwoordigd, net als mensen met een beneden modaal inkomen.

- Cosmopolitans (25\%): Cosmopolitans hebben relatief veel kennis. Ze weten dat ze uit zichzelf weinig duurzaam gedrag laten zien. Bedrijven en overheden moeten hen daarbij helpen. Een verplichting tot innovatieve, milieubeschermende maatregelen vinden ze prima. In vergelijking met Likers zijn ze kritisch; ze doen niet zomaar mee met het collectief. Het moet passen bij hun levensstijl. Cosmopolitans zijn jong en hoog opgeleid.

- Sceptics (15\%): Duurzaamheid is iets voor 'geitenwollensokkentypes', vinden Sceptics. Ze vertrouwen het MVO-beleid van bedrijven en overheden nauwelijks en zien de urgentie van het milieuprobleem niet zo. Sceptics zijn laggards als het gaat om opnemen van innovaties. Zij vinden relatief vaak dat ze niet begrepen worden en dat boodschappen niet voor hen bedoeld zijn. Mannen van $65+$ zijn oververtegenwoordigd.

Rogers' vijfdeling is terug te brengen tot een driedeling als we de 'extremen' onderscheiden van de mainstream. Meer specifiek: veel empirisch consumentenonderzoek is terug te brengen tot een relatief klein consumentensegment waarin verandering vooropstaat (denk aan: biologisch etende consumenten, bezitters van een elektrische auto, mensen die stelselmatig eerlijke kleding kopen of principieel bellen met een fairphone dan wel bankieren bij een duurzame bank), gevolgd door een grote hoofdmoot en ten slotte een minderheid die ongeïnteresseerd is. Grofweg hebben we het dan respectievelijk over voor- en achterlopers, en traditionelen.

\footnotetext{
${ }^{2}$ Zie: http://www.samr.nl/mvo-kaart-5-typen-duurzame-consumenten-in-kaart/
} 
Onderzoek leert en bevestigt dus vaak dat verandering klein begint. Een bescheiden kopgroep van consumenten zet een nieuwe koers. Overigens hoeft traditie niet per se haaks te staan op transitie, zoals kan worden geïllustreerd aan de hand van de cultuurtheorie van Mary Douglas (1996). Hierin wordt onderscheid gemaakt hiërarchisten, individualisten, egalitaristen en fatalisten. Seyfang (2007) heeft de eerste drie groepen in verband gebracht met duurzame consumptie. Aan de hand van deze groepen kan er enig licht worden geworpen op traditie als motivatie voor verduurzaming:

- Hiërarchisten betrekken duurzame consumptie met name op wat in de sociale omgeving als verantwoord of statusverhogend wordt beschouwd en zowel in traditie als in wet- en regelgeving is ingekaderd. Er is sprake van conformisme aan de dominante publieke opinie. Hiërarchisten zijn gevoelig voor wat als politiek correct geldt of anderszins politiek-maatschappelijk wordt verordonneerd. Zodra duurzaam consumeren in dergelijke kaders komt te staan, zal het draagvlak krijgen onder hen. Hiërarchisten zullen in de alledaagse praktijk waarschijnlijk de nodige gevoeligheid aan de dag leggen voor een luxe hybride auto of een 'diervriendelijk' stukje kwaliteitsvlees.

- Kenmerkend voor egalitaristen is daarentegen hun anti-moderne gedachtegoed waaraan desnoods radicale consequenties worden verbonden. Duurzame consumptie krijgt dan invulling in de vorm van consuminderen en er wordt tegenwicht geboden aan de heersende opvatting dat welbevinden en geluk een kwestie is van hebben en uitgeven van geld. Egalitaristen worden in het alledaagse taalgebruik vaak als 'alternativo's' aangeduid.

- Van terughoudendheid en traditionalisme als onderdelen van de leefstijl van hiërarchisten en egalitaristen is geen sprake als het om de individualisten gaat. Hun verhouding tot duurzame consumptie is er een waarbij duurzaam gelijkstaat aan een weelderige consumptie van groene(re) producten en diensten. Modernisering van het aanbod in een groene richting moet erop gericht zijn dat doorgegaan kan worden met consumeren en het bevredigen van behoeften die het welbegrepen eigenbelang dienen. Individualisten zullen in hun alledaagse doen en laten zoeken naar combinaties principes en profijt; van idealisme en individueel voordeel. Investeren in zonnepanelen op het dak, die zowel volop comfort als een lagere energierekening opleveren, vormen voor individualisten ongetwijfeld een aansprekende gedragsoptie.

\subsubsection{Van homo economicus naar burgerconsumenten}

In overeenstemming met de in par. 2.2.1 geschetste ontwikkeling waarin consumenten worden gezien als meerduidige wezens die potentieel vele rollen kunnen spelen en invulling geven aan pluriforme consumptiestijlen zien we dat de aloude scheidslijnen tussen consument en burger verwateren en in elkaar overvloeien. Burgerwaarden - zoals zorg en verantwoordelijkheid voor een 'betere' wereld dringen door in consumentenwensen en -behoeften die zich voornamelijk centreren rond eigenbelang en zaken als productkwaliteit en prijs-kwaliteitsverhouding. Kortom, hooggestemde idealen versmelten met plat individueel voordeel; een pragmatische inborst wordt gecombineerd met principes. De burgerconsumenten (citizen consumers) laten zich in moderne literatuur bijvoorbeeld betitelen met culturele creatieven, verantwoorde consumenten, alternatieve hedonisten of Lohas (lifestyles of health and sustainability). ${ }^{3}$ In al deze gevallen is de grens tussen wat 'des burgers' is en wat 'des consuments' vervaagd of zelfs verdwenen. Mensen in hun hoedanigheid van consument bezitten eveneens maatschappelijke focus en verantwoordelijkheid - net zo goed als dat burgers calculerend kunnen zijn.

De relativering van het verschil tussen de mens als burger en als consument ondersteunt de tendens om consumenten als méér te zien dan als prijspakkers die louter geïnteresseerd zijn in zoveel mogelijk voor zo weinig mogelijk geld. Natuurlijk, prijs is van niet te onderschatten belang - zie het succes van allerhande on- en offline discounters in diverse branches (van Lidl en Aldi tot Primark en Action). Maar hoewel het marktsucces van dergelijke prijsstunters doet geloven dat de 'geen cent te veel' altijd en alleen allesbepalend is, is niets minder waar. Het veronderstelde primaat van het individuele eigenbelang, als kernassumptie van het rationele keuzemodel, is niet per definitie de dominante gedragsdeterminant.

\footnotetext{
${ }^{3}$ Uit onderzoek van onderzoeksbureau Market Response in 2011 blijkt dat circa 2 miljoen Nederlanders behoren tot de culturele creatieven. Dat zijn mensen die zich zorgen maken over de toekomst van de aarde en kritisch staan tegenover materialisme en economisch gewin.
} 
Het samensmelten van de bewuste en verantwoorde burger en egoïstische en materialistische consument biedt ruimte aan invloeden op consumptiegedrag die sociaal, ethisch, emotioneel of politiek geladen zijn. Dit betekent dat maatschappelijke impact of langetermijnconsequenties (bijvoorbeeld voor klimaatverandering of wereldvoedselproblematiek) medebepalend zijn voor de afwegingen en gedragskeuzes die we maken. Dit perspectief werpt niet alleen een realistischer licht op het menselijk doen en laten, maar is ook direct relevant als het gaat om betrokkenheid van consumenten bij verduurzaming of vergroening. Immers, als behalve productkwaliteiten en prijs ook milieuvervuiling, verspilling, fair trade, mensenrechten of rechten van dieren gewicht in de schaal kunnen leggen, dan zijn consumenten niet alleen in te delen op basis van hun veranderingszucht of hun prijsbewustzijn, maar ook in hun duurzaamheidsgezindheid. Daarmee verschuift het zwaartepunt van de laagste prijs of de voordeligste deal naar aspecten die vaak ver verwijderd of niet direct betrekking hebben op het eindproduct. 'Eerlijk' eten is niet automatisch lekkerder dan doorsnee-eten en 'eerlijke' kleding draagt niet noodzakelijkerwijs beter. De meerwaarde van dergelijke consumptiegoederen zit voor mensen in het goede gevoel (belevingswaarde) en/of de wetenschap dat bepaalde kenmerken of kwaliteiten van de productiewijze in acht worden genomen waar ze waarde aan hechten.

Het antwoord op de vraag hoe realistisch het is dat hedendaagse consumenten natuurinclusieve keuzes maken en natuurbetrokken gedrag tentoonspreiden mag hoopvoller zijn als we de 'groene' profielen van burgerconsumenten in ogenschouw nemen. Deze indiceren immers dat burgerconsumenten - in potentie - bondgenoten kunnen zijn in processen van verduurzaming en vergroening. Behalve de inzet op donkergroene consumentensegmenten, is een bredere mix van motieven te benutten. Er zijn, met andere woorden, meerdere en lichtere tinten groene consumentengroepen aan te spreken als combinaties worden gevonden van bijvoorbeeld groen en goedkoop, groen en exclusief, groen en gezond, groen en gemak, groen en hypermodern, groen en goed gevoel, e.d. Daaraan kan, tot slot, worden toegevoegd dat de mate waarin burgerconsumenten natuurinclusief gedrag kunnen en willen vertonen niet alleen moet worden gezien als een kwestie van intrinsieke motivatie van individuele mensen, maar in belangrijke mate gerelateerd is aan de situationele omstandigheden (zoals de fysieke en sociale omgeving).

\subsection{Transitietheorie en de Rijksnatuurvisie}

\subsubsection{Inleiding}

Binnen de transitietheorie, of transitiemanagement, draait het om het omgaan met hardnekkige maatschappelijke vraagstukken, waarbij vernieuwende samenwerking de kern is (Rotmans, 2003). Het natuurbeleid is zo'n hardnekkige vraagstuk. Het werd beschouwd als een technocratisch en te veel door de overheid geleid beleid waar mensen zich van vervreemd voelden (Hajer, 2011). De Rijksnatuurvisie Natuurlijk verder van 2014 probeert hier verandering in te krijgen en bevat een visie en strategie voor het natuurbeleid van de komende jaren, gericht op een omslag in het zowel het denken als het doen. De kern: natuur moet nadrukkelijk een onderdeel van de samenleving worden. Natuur en economie kunnen elkaar uitstekend versterken. Bovendien, de verantwoordelijkheid voor natuur is niet langer het alleenrecht van de overheid, maar een brede maatschappelijke betrokkenheid moet de basis zijn.

De Rijksnatuurvisie moet gezien worden in een kader waarin de provincies meer invloed hebben gekregen. De twaalf bestuursakkoorden ILG (Investeringsbudget Landelijk Gebied) zijn vervangen door een decentralisatieakkoord dat geldt tot 2021. De provincies zijn vanaf 2014 financieel verantwoordelijk voor het beheer van Natuurnetwerk Nederland (NNN, voorheen EHS) ${ }^{4}$. Het Rijk zal na overleg met de provincies belemmeringen in de wet- en regelgeving wegnemen. Ongeveer 15 rijkstaken vervallen, waaronder de nationale parken, nationale landschappen, landschappen generiek, milieukwaliteit NNN, de Reconstructie, recreatie om de stad en robuuste verbindingszones. Verbetering van de dienstverlening aan burgers en bedrijven staat centraal. Beleid en uitvoering

\footnotetext{
${ }^{4}$ NNN staat voor Natuurnetwerk Nederland; EHS staat voor Ecologische Hoofd Structuur
} 
worden vereenvoudigd, toezichtstaken en adviesfuncties samengevoegd, taken beëindigd of gedecentraliseerd en er komt meer deregulering en meer private betrokkenheid, mede door meer synergie tussen natuur en andere belangen, zoals waterveiligheid, recreatie, ondernemerschap, gezondheid, energie en klimaat. Het Rijk richt haar contacten met medeoverheden op het gewenste eindbeeld. Dit heeft gevolgen voor overleg en vormgeving van decentralisaties en financieringsarrangementen. Het zogenoemde Natuurpact (september 2013) bevat afspraken met de provincies over de ambities tot 2027 en hoe de provincies deze kunnen realiseren. Dit plan is volgens toenmalig staatssecretaris Dijksma in nauw overleg met maatschappelijke partners (dat wil zeggen natuur- en milieuorganisaties, agrarische organisaties, waterschappen, gemeenten en bewonersorganisaties) tot stand gebracht en zal leiden tot een aantrekkelijke en maatschappelijk waardevolle natuur in Nederland én tot groei van de werkgelegenheid.

Voor het kabinet betekent dit allemaal een omslag in denken: van natuur beschermen tégen de samenleving naar natuur versterken mét de samenleving. Dit is de basis voor een transitie (zie Tekstbox 2) gericht op een nieuwe verhouding tussen overheid en samenleving en met een intensiever en breder maatschappelijke betrokkenheid, waarbij het aan de maatschappelijke partners is om het natuurbeleid inhoud te geven.

\section{Tekstbox 2:}

Transitietheorie - samen aan de slag

Het uitgangspunt voor de transitietheorie is de aanwezigheid van verstrekkende en hardnekkige problemen, zogenaamde 'wicked problems', ofwel ongetemde problemen (Hoppe 1989; Rotmans, 2003). In het kort heeft de 'wickedness' betrekking op een maatschappij die ingewikkeld en omgeven door onzekerheden is. De problemen waar het om gaat zijn hardnekkig en laten zich slechts moeizaam ordenen of structureren. De transitietheorie stelt daarom dat participatie in gezamenlijke leerprocessen nodig is, in een gezamenlijk agendabouwproces waar men werkt aan een wederzijds vertrouwen, richting een commitment. De partijen moeten elkaar kunnen vinden in gedeelde probleempercepties. Dat vraagt niet alleen begrip voor elkaars belangen, maar ook vertrouwen in het feit dat het relativeren van de eigen aanvankelijk ingenomen belangenpositie vruchten afwerpt. Dit is allerminst vanzelfsprekend, want velen vinden hun ingenomen positie de juiste, en afwijkingen zijn ongewenst. Bovendien dient er aandacht te zijn voor een gelaagde schaalproblematiek. Op microniveau gaat het om het ontwikkelen van niches, met mogelijke afwijkingen van het bestaande, zoals nieuwe technologieën, initiatieven, culturen en sturingsvormen. Op mesoniveau gaat het om de regimes, om stelsels van dominante praktijken, regels en belangen. En op macroniveau gaat het om 'landschapsveranderingen', in termen van politiek, cultuur, wereldbeelden en paradigma's. De transitietheorie is gebaseerd op een coalitie van welwillenden (coalition of the willing). Niet iedereen hoeft dus vanaf het begin af aan mee te doen. Deze welwillenden gaan gezamenlijk aan de slag met de transitie-management-cyclus in vier stappen (Rotmans, 2003; Loorbach en Rotmans, 2010):

i) een gezamenlijk probleemdefinitie met een visie en een transitiearena;

ii) het ontwikkelen van coalities en toekomstbeelden voor de transitiearena;

iii) het mobiliseren van actoren en projecten en operationele experimenten; en

iv) het monitoren en evalueren voor een reflexieve leerproces.

Een visie is hier het vergezicht waar de partijen samen naar toe willen, plus de weg daar naar toe; ofwel een aanzet tot een plan. Een transitiearena is de ontmoetingsplek waar men de transitie samen ontwikkelen. De coalities zijn samenwerkingsverbanden rond concrete plannen om de natuuromslag te realiseren. Het monitoren en evalueren met een zogenaamd reflexieve leerproces verwijst naar de nadruk op het gezamenlijke en het leren als basis voor het evalueren en niet beoordelen en afrekenen. Concepten als transitiearena en bijvoorbeeld reflexieve leerprocessen zijn voor velen spannende en aantrekkelijke termen. In de praktijk is er echter een risico dat de stap naar de praktische plannen lastig wordt. Er is een gevaar voor vervreemding wanneer de mooie concepten omgezet worden in een 'gewoon' plan met de weerbarstigheid en grilligheid die daaraan verbonden is (Selnes en Aalders, 2005). 
De rol van het Rijk is inhoud geven aan de zogenaamde stelselverantwoordelijkheid, voor zowel internationale als de nationale opgaven. Dit betekent onder meer deelname aan het internationale overleg- en besluitvormingscircuit, maar ook de verplichting te investeren in een natuur van voldoende omvang en kwaliteit in Nederland. Naast deze traditionele invulling van de stelselverantwoordelijkheid heeft het kabinet er een nieuwe dimensie aan toegevoegd: het mogelijk maken en bevorderen van de betrokkenheid van anderen; dat wil zeggen, dat andere overheden, burgers, maatschappelijke organisaties en ondernemers met hun inzet de waarde van natuur vergroten. Dit laatste is, in transitietermen, de basis voor een arena voor samenwerking. Het maakt ook dat het Rijk en andere partijen van elkaar afhankelijk zijn, als onmisbare partners. In vergelijking met het verleden gaat de Rijksoverheid meer faciliteren en samenwerken. 'Ondersteunen' is nu het motto waar men vroeger 'opleggen' riep. Hiërarchische sturing is van tafel en minder dwingende sturingsvormen rukken op. Een brede betrokkenheid en groen ondernemerschap kan bijdragen aan een sterke natuur, stelt de regering. Dit concreet maken staat nu centraal, en daar heeft het Rijk acht doelen voor geformuleerd.

\subsubsection{Acht doelen voor de toekomst}

De komende vijftien tot twintig jaar zet het Rijk in op acht doelen. Hierbij staan de maatschappelijke partijen voorop en faciliteert de overheid. Deze doelen zijn ook in figuur 1.2 weergeven:

- Groen ondernemerschap;

- Natuurinclusieve landbouw;

- Gebiedsontwikkeling met natuurcombinaties;

- Groen wonen en werken;

- Toekomstbestendige natuur;

- Effectieve wetgeving;

- Ontwikkelen en bouwen met natuur;

- Open en lerend kennisnetwerk.

We kunnen deze doelen of uitdagingen zien als onderdelen van de transitiearena, waar coalities zich moeten vormen. Voor elk van de acht zijn er 'Groene Tafels' gehouden en ' Green Deals' afgesloten, om de dialoog op gang te brengen, de praktische invulling te realiseren en de nodige leerprocessen op gang te brengen. Zo gaan bedrijven onder de vlag van ' Groen ondernemerschap' de zorg voor biodiversiteit verankeren in hun bedrijfsstrategie, ketens vergroenen en komt er meer transparantie over de invloed van een bedrijf op natuurlijk en sociaal kapitaal. Het Rijk ondersteunt via een reeks samenwerkingsverbanden, waarbij de uitdagingen zijn gelegen in daar waar maatwerk nodig is. Zo geldt voor bijvoorbeeld de gebiedsontwikkeling met natuurcombinaties dat men op zoek is naar nieuwe verdienmodellen - denk aan combinaties met gezondheid en welbevinden voor mensen. Het is de provincie die hierbij de regierol heeft.

Met de acht nieuw geformuleerde doelen verschuiven oudere doelen van het Rijk. Met het doel toekomstbestendige natuur, bijvoorbeeld, verschuift de aandacht van afzonderlijke beschermde soorten en gebieden naar de schaal van landschappen, zoals in het rivierengebied en het duingebied. Robuuste landschapssystemen zullen zorgen voor lage beheerskosten en haalbare natuurdoelen. Het Rijk gaat daarbij nog wel soorten en habitats beschermen die nog ver verwijderd zijn van een goede instandhoudingssituatie. Dit is een harde verplichting, stelt het kabinet vast, en 'daarvoor spannen we ons maximaal in'. De uitdaging hier is dat dit een opleggend stuk beleid is, terwijl transitie juist vraagt om een aanpak van gezamenlijkheid.

\subsubsection{Nieuwe rollen en veranderende verhoudingen}

De nieuwe aanpak in het natuurbeleid vraagt om aanpassing van de rolverdeling tussen Rijk en de provincies. De kern daarvan is de afspraak dat bij het realiseren van het natuurbeleid, het Rijk de provincies uitsluitend zal aanspreken over doelbereik indien er sprake is nalatigheid, zonder een aparte verticale toezichtrelatie. Spanningen tussen economie en natuur worden benoemd en van mogelijke oplossingen voorzien. Zo wenst men onbegrip, ergernis en weerstand weg te werken en ook het beeld van natuurbeleid als hindermacht. 
Tegelijkertijd is het echter meestal de minister die aangesproken wordt op het natuurbeleid, en ter verantwoording wordt geroepen als er iets aan de hand is. Het ministerie zal dan op tijd willen weten wat er speelt, maar tevens zal men terughoudend zijn bij het opvragen van informatie bij de provincie, want dat kan het gevoel van controle opwekken. De oplossing hiervoor wordt gezocht in een nieuw sturingsprincipe: de wettelijke bevoegdheden worden gelegd bij de overheden die daarvoor het meest in aanmerking komen. Deze bevoegde overheid krijgt een cruciale rol, namelijk het bepalen van hoe een activiteit kan worden toegelaten op een manier dat recht doet aan wat er in de praktijk nodig is. Veel bevoegdheden zijn naar de regio gegaan, met de provincie als de gebiedsregisseur die de partijen bij elkaar brengt en het voortouw neemt bij de uitvoering. De rol van de overheid schuift op van een vaak overheersende naar eentje die meer weg heeft van 'partner', 'opdrachtgever' en 'facilitator'. Het beleid wordt meer opengesteld voor overleg, onderhandelingen en het overlaten aan maatschappelijke partijen.

Transitiemanagement vereist een zekere gezamenlijkheid bij het ontwikkelen van zowel een agenda als de kennis die daarvoor nodig is. Dat heeft het Rijk begrepen en de zogenaamde 'lerende netwerken' vormen nu de leidende term voor de kennisagenda van het Rijk. Samenwerkingsverbanden kunnen en zullen ontstaan als gevolg van de nieuwe manier van kennis ontwikkelen en delen. De Rijksoverheid stimuleert meer betrokkenheid van andere overheden in de door het Rijk aangestuurde onderzoeksnetwerk. Dit zijn voor het kabinet allemaal essentiële bouwstenen voor de leerprocessen die nodig worden geacht, waarbij het kabinet niet nalaat te benadrukken dat dit alles slechts eerste stappen zijn in een langer veranderingsproces. Voor de stap naar de praktijk maakt het ministerie van EZ zich sterk voor natuurcombinaties met energie, bedrijven en landbouw. Overheden en maatschappelijke partijen werken daarom aan een gezamenlijk ontwikkeld maatschappelijke uitvoeringsprogramma voor natuurcombinaties.

De verhouding met de maatschappij is hiermee op een weg beland met veel ruimte voor maatschappelijke zelfregulering en vernieuwing. Waar natuur vroeger gezien werd als vooral een ecologisch verhaal, is het nu breder en natuur is meer gepositioneerd als een maatschappelijk vraagstuk. Er komt meer flexibiliteit, bijvoorbeeld in hoe de natuurcombinaties vorm en inhoud krijgen. Het Rijk is echter eindverantwoordelijk, met wetgeving als stok achter de deur. Daarbij is ze niet alleen één van de spelers binnen de transitiearena, maar tegelijkertijd bepaalt ze ook de spelregels en is ze scheidsrechter. Over situaties waarin één van de 'gelijkwaardige' spelers ook andere rollen vervuld, is in de transitieliteratuur niet veel te vinden. De vraag is wat deze verschillende petten van het Rijk betekent voor het vertrouwen tussen Rijk en de maatschappelijke partijen.

Het is verre van uitgesloten dat er discussie komt over interpretaties van wie wat mag zeggen en bepalen. Een belangrijk punt is dat de provincies zelf de weg mogen uitstippelen. Dat kan leiden tot verschillen in de aanpak tussen de provincies, en dat kan dan weer botsen met landelijke normen voor een gelijke behandeling ongeacht waar in het land iemand zich bevindt. Bovendien is de provinciale regierol in vele opzichten nieuw, en het terugvallen op al bestaande praktijken is daarmee beperkt (Kamphorst et al., 2015).

In het verleden waren vele conflicten geworteld in een focus op ecologische effectiviteit, vanuit een technisch en juridisch taalgebruik. De focus was nooit maatschappelijk, en is dat nu wel - meer dan voorheen. Tegelijkertijd is het de vraag of nieuwe, meer maatschappelijke ingestoken concepten zoals ecosysteemdiensten en natuurlijk kapitaal, ook niet leidt tot een nieuwe vorm van technocratisering.

De regering benadrukt dat de Natuurvisie een strategisch en geen statisch document is. Het gaat om een verandering in het denken en doen; een routekaart voor de lange termijn. Vele veranderingen zijn al lang begonnen, en het kabinet benadrukt dat de veranderingen beslist niet altijd door de overheid in gang zijn gezet. 


\subsection{Zitten we midden in een transitie?}

In het digitale tijdschrift Sociale Vraagstukken (www.socialevraagstukken.nl) loopt een vurige polemiek tussen enerzijds Rotmans en anderzijds Tonkens en Duyvendak. Deze discussie laat zien hoe verschillen in inzicht voor de huidige ontwikkelingen kunnen botsten. In de kern draait de polemiek om de vraag of er al dan niet sprake is van een transitie naar een samenleving die streeft naar een betere, innovatievere en minder bureaucratische wereld, of dat deze constatering van een zogeheten nieuwe werkelijkheid overtrokken is.

Volgens Rotmans is er inderdaad sprake van een transitie met bijbehorende paradigmawisseling. Hij stelt in het artikel 'Nederland kantelt ondanks of dankzij scepsis': "Nederland kantelt van een verticaal geordende, centraal aangestuurde, top-down samenleving naar een horizontale, decentrale, bottomup samenleving. Langzaam maar zeker wordt de oude ordening van bestaande instituties en organisaties vervangen door gemeenschappen, coöperaties en sociale en fysieke netwerken." Het gevolg, aldus de Rotterdamse hoogleraar transitiekunde, is een beweging van onderop die een nieuwe maatschappelijke ordening tot stand brengt. We zijn getuige van het ontstaan van een hele nieuwe wereld, zo schrijft Rotmans: "We maken de Genesis mee van een derde wereld, naast de al bestaande bestuurlijke wereld en de echte, alledaagse wereld komt de gedroomde wereld van ondernemende burgers of sociaal ondernemers op." Elders herhaalt Rotmans nog eens nadrukkelijk dat we middenin een transitie zitten, waarbij alles draait om burgers die zichzelf organiseren in uiteenlopende initiatieven, en dat deze transitie - mocht deze slagen - zal leiden tot een hoger complexiteitsniveau en een hoger niveau in de evolutie.

Tonkens (hoogleraar burgerschap en humanisering van de Publieke Sector) en Duyvendak (hoogleraar sociologie) zijn terughoudender en plaatsen vraagtekens bij Rotmans' (in hun ogen) grote woorden. Zij zijn sceptisch over beweringen die stellen dat er een beweging van onderop gaande is, waardoor er een samenleving 3.0 aan het ontstaan is. Het concept burgerinitiatieven, waar Rotmans de loftrompet over steekt, is volgens hen minder eenduidig dan het lijkt. Geregeld worden dergelijke initiatieven door de overheid geïnitieerd en door (betaalde) ondernemers gedragen. In hun artikel 'Graag meer empirische en minder eufore kijk op burgerinitiatieven' schrijven Tonkens en Duyvendak: "Of we hier getuige zijn van een grote maatschappelijke omwenteling is nog maar de vraag. (...) Dat sommigen desondanks de indruk van een ontploffing krijgen, komt vermoedelijk doordat beleid, politiek en media er veel meer aandacht aan besteden dan voorheen." (Tonkens en Duyvendak, 2015).

Hoe het ook zij, Rotmans staat niet alleen met zijn idee van een (aanstaande) omwenteling, transitie of paradigmawisseling. De veel gelezen Amerikaan Jeremy Rifkin voorspelt een grondige hervorming van het kapitalisme en het ontstaan van een nieuwe economie die bestaat uit delen en samenwerken. In zijn boek 'De derde Industriële Revolutie' (2014) beschrijft Rifkin de pijlers voor een nieuw economisch stelsel. Dit stelsel is gericht op een groene toekomst, waarbij een overstap wordt gemaakt van een op koolstof en fossiele brandstof gebaseerd energieregime naar een regime van groene, hernieuwbare energie. Hij stelt dat groene, hernieuwbare energie (samen met internettechnologie) voor de derde industriële revolutie zal zorgen, en dat deze een transformatie van economie en samenleving zullen bewerkstelligen.

Transitie of niet, er is een omslag gaande in het natuurbeleid, waarbij alles draait om natuur midden in de samenleving en niet alleen in beschermde natuurgebieden. De Rijksnatuurvisie Natuurlijk verder is erop gericht om burgers, bedrijven, gemeenten en maatschappelijke organisaties meer kansen te bieden natuur te beschermen en om natuur duurzaam te gebruiken. Dit leidt onder meer tot nieuwe financiële en bestuurlijke constructies. De provincies zijn sinds 2013 verantwoordelijk voor een goede uitvoering van deze nieuwe stijl natuurbeleid. Kortom, Rijk, provincies, maatschappelijke partijen en gebiedspartners (zoals gemeenten en bewonersorganisaties) werken tezamen aan een natuur die ruimte biedt voor ontspanning en bijdraagt aan de economische ontwikkeling van Nederland. Een natuur die aansluit op de wensen van burgers, bedrijven en particuliere organisaties. 


\section{Achtergrond Rijksnatuurvisie en uitwerkingen}

\subsection{Introductie}

Het idee dat burgers, bedrijven en maatschappelijke organisaties een medeverantwoordelijkheid hebben bij behoud van natuur in Nederland, zoals beschreven in de Rijksnatuurvisie, komt niet uit de lucht vallen. In paragraaf 3.2 beschrijven we eerst in het kort de geschiedenis van natuurbeheer en de rol van maatschappelijke initiatieven daarin. En vervolgens enkele nota's die vooraf gingen aan de Rijknatuurvisie, waarin het belang van de ondernemende maatschappij al wordt geagendeerd. Maar er zijn ook andere geluiden, en die komen ook aan bod.

In paragraaf 3.3 geven we een overzicht van de verschillende instrumenten die de overheid inzet om groene initiatieven vanuit het bedrijfsleven te stimuleren. Omdat de activiteiten vanuit het bedrijfsleven voor natuur heel divers zijn, wordt in paragraaf 3.4 enige structuur aangebracht in de activiteiten. Daarbij wordt ook een overzicht gegeven van motieven om bij te dragen aan natuur. Tot slot de lessen die we kunnen trekken uit dit hoofdstuk (par. 3.5).

\subsection{Achtergrond natuurinclusief handelen}

\section{Geschiedenis natuurbeheer: van particulier initiatief naar overheidsbeleid en terug}

De eerste initiatieven om natuur te beschermen komen van burgers. ${ }^{5}$ In 1905 wordt door particulieren de Vereniging tot Behoud van Natuurmonumenten opgericht met als doel de aankoop van het Naardermeer, om hier een beschermd natuurgebied van te maken. Een beschermd natuurgebied is op dat moment uniek voor Nederland. Tussen 1926 en 1936 worden elf Provinciale Landschappen opgericht, alle particuliere terreinbeherende instanties. De eerste natuurwetgeving omvat de Natuurschoonwet (1928) en de Vogelwet (1936). Staatsbosbeheer, zoals de naam al zegt een overheidsinstantie, was in eerste instantie gericht op houtproductie, maar zet zich sinds 1929 ook in voor 'bescherming van natuurschoon'. Momenteel beheert Staatsbosbeheer het grootste areaal natuurgebied in Nederland. Ook de drinkwaterbedrijven in ons land bezitten veel natuur, met name in het duingebied. Drinkwaterbedrijven hebben een hybride karakter, tussen overheid en bedrijf in. ${ }^{6}$ De Amsterdamse Waterleidingduinen zijn in 1853 in gebruik genomen voor de productie van drinkwater voor Amsterdam. Later wordt natuurbeheer een tweede doelstelling, naast waterwinning.

In de periode direct na de Tweede Wereldoorlog verslapt de aandacht voor natuur. De wederopbouw eist alle aandacht op, ook al gaat dit soms ten koste van de natuur. Vanaf de jaren zestig groeit de aandacht voor natuur en milieu. Dit wordt door het rapport van de Club van Rome uit 1972, over grenzen aan de groei, verder gestimuleerd. Door de toenemende vrije tijd en het autobezit groeit de recreatiesector en het besef dat welzijn niet alleen gebaseerd is op economische vooruitgang maar ook op rust en ruimte. Dit besef leidt tot steeds meer beleid voor natuur, milieu en landschap. En tot steeds meer wet- en regelgeving, in Nederland en ook op Europees niveau. De particuliere terreinbeherende instanties, zoals Natuurmonumenten, groeien en professionaliseren. Er ontstaat een natuursector, met experts en een eigen jargon. In 1990 wordt in de Natuurbeleidsplan de Ecologische Hoofdstructuur (EHS) geïntroduceerd, inmiddels Natuurnetwerk Nederland (NNN) genoemd. Dit wordt een belangrijke leidraad van het natuurbeleid. Ondertussen ontstaat rond de Oostvaardersplassen een uniek natuurgebied, enkel omdat het met rust wordt gelaten. Het idee was dit gebied te ontwikkelen als industrieterrein wanneer de tijd er rijp voor is, maar er ontstaat spontaan 'wildernisnatuur'. Deze

\footnotetext{
${ }^{5}$ Deze paragraaf is grotendeels gebaseerd op Klijn (2011).

${ }^{6}$ Drinkwaterbedrijven zijn in meerderheid naamloze vennootschappen met gemeenten en provincies als aandeelhouders (met uitzondering van Waternet, een stichting, en Evides Drinkwater BV).
} 
wildernisnatuur komt te staan naast 'arcadische natuur', dat wil zeggen een natuurbeeld waarin ook plaats is voor cultuurlandschappen zoals het agrarische landschap.

Rond de millenniumwisseling ontstaat een kentering. De natuurliefhebbers raken verdeeld: sommigen zijn voorstander van wildernisnatuur, anderen prefereren arcadische natuur. De economische crisis zorgt voor nieuwe aandachtspunten voor het beleid. Bovendien wil men af van het technocratische systeem waarbij beheerders worden afgerekend op 'natuurdoeltypen' en ingewikkelde rapportages. Wanneer bouwprojecten worden vertraagd door zeldzame diersoorten als de korenwolf en de duinhagedis, ontstaat bij het bedrijfsleven het idee dat Nederland 'op slot' zit. Het bedrijfsleven ziet de natuurwetgeving steeds meer als hindernis. In 2008 wordt de Crisis- en Herstelwet aangenomen, om procedures te verkorten en aanbestedingen te versnellen. Maar de natuurwetgeving vanuit Brussel blijft onverminderd van kracht.

Het afgelopen decennium is het natuur en landschapsbeleid gedecentraliseerd, van Rijk naar provincies. Bovendien kiest het Rijk voor meer governance en minder government, dat wil zeggen, minder van bovenaf opleggen en meer samenwerken met de markt en maatschappelijke organisaties. Vanuit de EU blijft men echter werken met wet- en regelgeving, en het Rijk is verantwoordelijk voor de uitvoering van Brussels beleid op nationaal niveau.

De Rijksnatuurvisie sluit aan bij het idee van governance, en benadrukt het belang van natuur dicht bij de mensen en dus van arcadische natuur. Dit alles vanuit het idee dat het maatschappelijk draagvlak voor natuur vergroot moet worden. Maar de Rijksnatuurvisie wijst ook op de internationale verplichtingen en de verplichtingen ten aanzien van EU-wetgeving.

\section{De energieke samenleving en de terugtrekkende overheid}

De Rijksnatuurvisie (2014) is vooraf gegaan aan een aantal rapporten waarin het belang van particuliere initiatieven gecombineerd met een faciliterende en netwerkende overheid, wordt beschreven. Hieronder een kort overzicht.

Hajer (2011) propageert de energieke samenleving. De overheid moet beter gebruik maken van de energie, het leervermogen en de creativiteit van de samenleving, en de innovatiekracht van bedrijven beter benutten. De energieke samenleving vraagt om een andere overheid, met andere taken. De nieuwe taak van de overheid is niet zozeer het stellen van grenzen, maar het motiveren van burgers en bedrijven om op duurzame wijze te produceren en te consumeren. Hajer heeft aandacht voor het feit dat de Nederlandse burger sterk hecht aan groen in de eigen leefomgeving, maar tegelijkertijd door zijn consumptiepatroon milieuproblemen elders veroorzaakt. Onze consumptie beïnvloedt een mondiaal systeem van diensten en materialen, en legt een zware druk op de draagkracht van de aarde (Hajer, 2011, blz. 7).

De Raad voor het Openbaar Bestuur (ROB, 2012) stelt dat de overheid de samenleving in staat moet stellen zelf het heft in handen te nemen in plaats van oplossingen van bovenaf te willen genereren. Dit vanuit het besef dat de financiële slagkracht van de overheid beperkt is én dat veel maatschappelijke vraagstukken te complex zijn geworden om opgelost te worden door de overheid. Daarbij is het van belang dat de overheid zich aanpast aan horizontale structuren in plaats van te denken in verticale, hiërarchische verhoudingen. Het particuliere initiatief moet leidend zijn en overheden dienen zich daarop aan te passen. De rolverandering van de overheid wordt een paradigmaverschuiving genoemd. Ook wordt een pleidooi gehouden voor een compactere overheid wat betreft pretenties en ambities.

De Wetenschappelijke Raad voor het Regeringsbeleid (WRR, 2012) onderschrijft pogingen van beleidsmakers om burgers te betrekken bij de samenleving, maar ziet dat slechts weinig burgers zich geroepen voelen. Grote groepen burgers ervaren de pogingen van beleidsmakers als ongemakkelijk of stellen zich onverschillig op. Toch zijn burgers inventief. Echter, veel initiatieven van burgers komen niet tot stand op uitnodiging van beleidsmakers, maar via andere kanalen. De WRR geeft adviezen om de betrokkenheid van burgers te vergroten. Beleidsmakers moeten daarvoor ruimte maken, en vertrouwen hebben in de burgers. 
Het Ministerie van Economische Zaken (2013) heeft een kennisprogramma opgesteld 'Duurzaam Door'. Het ministerie streeft naar een groene, duurzame economie, en om dat te bereiken wil men partijen bij elkaar brengen en uitdagen nieuwe oplossingen te vinden voor maatschappelijke problemen. Deze partijen, burgers, bedrijven, overheden, onderwijsinstellingen en maatschappelijke organisaties, kunnen van elkaar leren. Het beleid is gericht op sociale innovatie: zoeken naar mogelijkheden om ruimte te scheppen, kaders aan te geven, en partijen in de samenleving te ondersteunen bij netwerken, en om te gaan met regels en kennisdeling. "Op het vlak van de groene economie is enorm veel initiatief in de samenleving. Voor individuele partijen is het vaak lastig om verbindingen en opschaling te realiseren. De overheden kunnen daarbij een krachtige rol spelen. Een rol die mede vorm krijgt in dit kennisprogramma." (EZ, 2013, blz. 5).

De Nederlandse School voor Openbaar Bestuur (NSOB) en het Planbureau voor de Leefomgeving $(\mathrm{PBL})^{7}$ (2014) stellen dat een energieke samenleving niet vraagt om minder overheid, maar om aanvullende instrumenten bovenop het bestaande repertoire: naast de sturende rol van de overheid moet op een aantal terreinen ruimte geboden worden aan initiatieven vanuit de maatschappij en nieuw handelingsrepertoire voor ambtenaren ontwikkeld worden waarmee energie uit de maatschappij herkend, benut en aangeboord kan worden.

De overeenkomst tussen bovenstaande rapporten en de Rijksnatuurvisie is de wens om meer ruimte te scheppen voor initiatieven uit de maatschappij. De rol van de overheid moet daarom veranderen. Maar welke rol de overheid op zich moet nemen, daarover verschillen de meningen. De ambitie van de Rijksnatuurvisie, een natuurinclusieve economie, is erg ambitieus. Dit in tegenstelling tot wat de Raad van het Openbaar Bestuur adviseert: een compactere overheid wat betreft pretenties en ambities. Hajer, en NSOB / PBL zien niet zozeer een kleinere, maar een andere rol voor de overheid weggelegd.

Vooral in het rapport van de Raad voor het Openbaar Bestuur worden ideeën uit de transitietheorie aangehaald: problemen zijn te complex geworden voor de overheid, nieuwe coalities en netwerken moeten gevormd worden, experimenteerruimte is nodig, leervermogen en creativiteit van burgers en bedrijven benutten, een paradigmashift is wenselijk. Maar het begrip 'transitie' wordt alleen gebruikt in de Rijksnatuurvisie.

\section{Andere geluiden: een centrale, coördinerende rol voor de overheid}

Naast het idee dat initiatieven vanuit de samenleving omarmd moeten worden, zijn er ook auteurs die het belang van een centrale, coördinerende overheid benadrukken. Zij stellen dat de overheid een duidelijke missie moet formuleren, een masterplan, een langetermijnvisie, en: de overheid moet het voortouw nemen.

Mazzucato ${ }^{8}$ is een Italiaans-Amerikaanse econoom en zij houdt een pleidooi voor een overheid met een duidelijke, ambitieuze missie. Vergelijkbaar met 'we zetten voor het einde van dit decennium een mens op de maan'. En de overheid moet daar dan ook geld voor beschikbaar stellen. Hoe de missie dan vervolgens gerealiseerd wordt, bijvoorbeeld met welk type raket, is aan het bedrijfsleven en de wetenschappers. Maar de overheid wijst het doel aan en verstrekt de middelen. Het ontbreken van voldoende (overheids)geld is geen excuus, want er wordt al veel geld uitgegeven door de overheid aan innovatie. Ze wijst op diverse innovaties die geïnitieerd zijn door de overheid, en later op de markt gebracht door bedrijven. De overheid investeert in de hele innovatieketen: van fundamenteel onderzoek en productontwikkeling tot marketing. Mazzucato pleit ervoor (zoals geïllustreerd in figuur 3.1) om opbrengsten van succesvolle technologieën waar overheden een doorslaggevende aanzet toe hebben gegeven, zoals internet, af te romen en dat in te zetten voor een volgende grote innovatie. De overheid kán dus richting geven aan een transitie naar een groene maatschappij, maar moet dan wel een gericht mission-oriented beleid voeren, inclusief financieel beleid.

\footnotetext{
7 Hajer, genoemd hierboven, was tussen 2008 en 2015 directeur van het PBL en medeauteur van dit essay.

${ }^{8}$ Gebaseerd op PBL-Academie lezing Mariana Mazzucato, 27 maart 2015, Den Haag. Zie ook Mazzucato (2013): The Entrepreneurial State, en Mazzucato (2015): Mission-Oriented Finance for Innovation.
} 


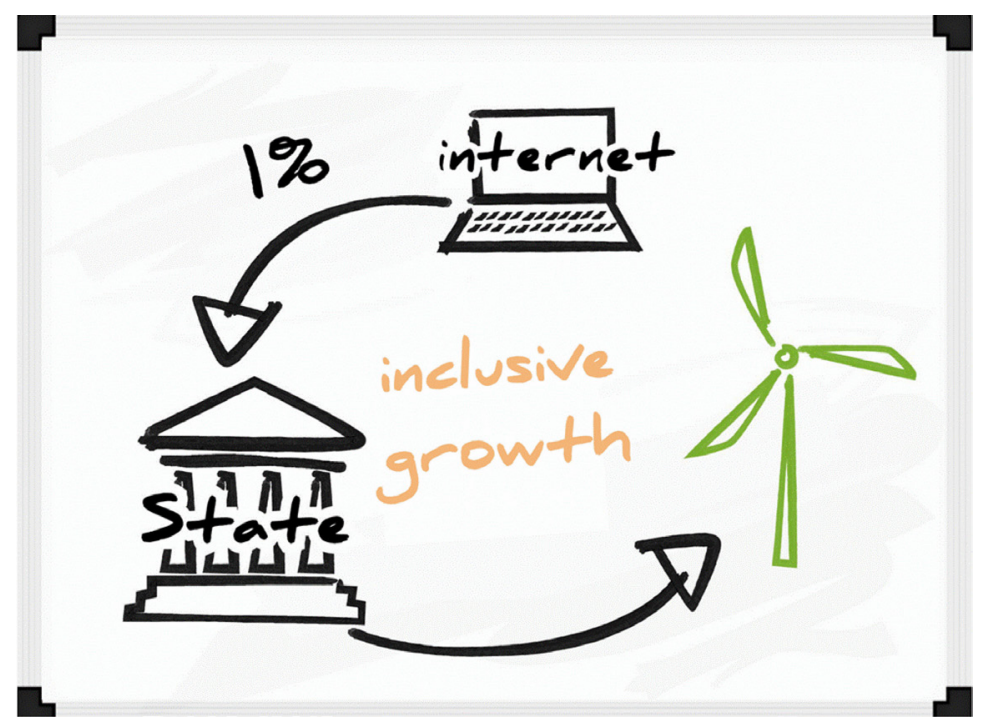

Figuur 3.1: Afromen succesvolle technologieën voor nieuwe, groene ontwikkelingen. Bron: Mazzucato, 2015 (power point slide bij presentatie)

Jeremy Rifkin $(2013,2014)$, een Amerikaanse econoom, stelt dat overheden een masterplan moeten opstellen om de overgang van fossiele naar duurzame energie in banen te leiden. Hij voorspelt het einde van het tijdperk dat de mondiale economie gebaseerd is op fossiele brandstoffen, en het begin van een derde industriële revolutie. Centraal in deze derde industriële revolutie staat op duurzame wijze geproduceerde energie, met name lokaal opgewekte en gedeelde energie uit wind, zon, biomassa, en geothermische energie. Deze duurzame energiebronnen in combinatie met nieuwe uitwerkingen van internet om de distributie te organiseren, zal leiden tot een 'energie-internet': miljoenen mensen in huizen, kantoren en fabrieken produceren en distribueren duurzame energie zoals nu informatie wordt gecreëerd en gedeeld via internet. Deze nieuwe vorm van productie en distributie van zo'n essentieel product als energie, leidt tot een grondige hervorming van het kapitalisme.

Miljoenen kleine spelers in plaats van een paar grote leidt tot de afbraak van het oude systeem vergelijkbaar met de opkomst van YouTube en de neergang van de muziekindustrie. Belangrijk daarbij is dat bij deze nieuwe vorm van productie de marginale kosten bijna nihil zijn. Dat maakt het mogelijk dat deze vorm van productie snel opgeschaald kan worden. Andere aansprekende voorbeelden van gedeelde productie en distributie zijn AirBnB en Uber. Doordat de marginale kosten zo laag zijn (de aanbieders hebben al een huis en een auto), kunnen deze bedrijven snel groeien. Rifkin stelt dat voor duurzame energie echter wel een infrastructuur aangelegd moet worden, onder meer om energie op te slaan, en de wetgeving moet aangepast worden. Hier ligt een taak voor regeringen om, in overleg met CEO's van grote bedrijven, te komen tot een masterplan. Wanneer regeringen hierin niet de leiding nemen, lopen we het risico dat de economische crisis doormoddert en dat klimaatverandering een onoplosbaar probleem wordt.

Niet alleen in het buitenland, maar ook in Nederland zijn vergelijkbare geluiden te horen. Allereerst van een drietal organisaties die milieubewuste bedrijven vertegenwoordigen, te weten De Groene Zaak, MVO Nederland en Circle Economy. In samenspraak met een aantal buitenlandse organisaties hebben zij een manifest opgesteld en doen zij een oproep richting politiek om leiderschap te tonen, meer specifiek voor een circulaire economie. In het manifest stellen zij: "Sterk overheidsbeleid is cruciaal voor het plukken van de vruchten van een circulaire economie. Dit vergt leiderschap en investeringen in circulaire innovatie. " (De Groene Zaak et al., 2015)

Zoals hierboven genoemd, stelde Hajer al dat Nederlanders hun directe leefomgeving graag groen zien, maar door hun consumptiegedrag een grote druk leggen op natuur en milieu elders in de wereld. Hierop aansluitend stellen Selnes et al. (2014) dat er nationaal een roep is naar vermaatschappelijking van het natuurbeleid, maar waar het gaat om internationale productie- en handelsketens er een vraag is naar actievere overheden bijvoorbeeld waar het gaat om landgebruiksconflicten. 
Een belangrijke overeenkomst tussen bovenstaande auteurs is het idee dat bedrijven en particulieren weliswaar van groot belang zijn bij hervormingen van het maatschappelijk systeem, maar dat de rijksoverheid (op een aantal thema's) een centrale, leidende rol op zich dient te nemen.

\subsection{Instrumenten van het beleid}

De overheid zet verschillende instrumenten in om een natuurinclusieve economie te stimuleren. Deze instrumenten kunnen onderverdeeld worden in: 1) overlegstructuren, 2) financiële regelingen, en 3) onderzoek.

\section{Overlegstructuren}

Green Deals hebben tot doel institutionele barrières weg te nemen voor duurzame initiatieven uit de samenleving. De rol van de overheid hierbij varieert per Green Deal, maar kan zijn: het wegnemen van belemmeringen in wet- en regelgeving, het toegankelijk maken van netwerken, of het ondersteunen van toegang tot de kapitaalmarkt.

Groene Tafels zijn overlegstructuren om de synergie tussen natuur en andere maatschappelijke doelen zoals gezondheid, waterveiligheid en economie te analyseren en te versterken. Diverse sectoren zijn hierbij betrokken, zoals de recreatiesector, de bouw, landbouw, gezondheidssector en de financiële sector. De te beantwoorde vraag is steeds: wat is het belang van groen voor deze sector en hoe kan synergie worden bereikt? Resultaten van de Groene Tafels zijn bijvoorbeeld het vormen van nieuwe coalities, het starten van pilotprojecten, en het ondertekenen van een intentieverklaring.

Community of Practice (CoP) Bedrijven en Biodiversiteit was een samenwerkingsverband tussen 15 bedrijven uit verschillende branches die ervaringen uitwisselen over de impact van hun bedrijfsactiviteiten op de omgeving. ${ }^{9}$ Doel is een bijdrage leveren aan groene groei en ook andere bedrijven te stimuleren hier aan mee te werken. Deze CoP is tot stand gekomen door middel van een Green Deal.

Platform Biodiversiteit, Ecosystemen en Economie (Platform BEE) is een initiatief van ondernemersorganisatie VNO-NCW en natuurorganisatie IUNC-NL, met financiële steun van het ministerie van EZ. Doel is behoud en herstel van biodiversiteit als voorwaarde voor economische groei. Aangesloten bij dit platform zijn onder andere LTO, Shell, DSM, FrieslandCampina, Unilever en Wageningen UR.

Leaders for Nature is een initiatief van IUCN NL, mede met steun van het ministerie van EZ, en bestaat uit de volgende bedrijven: ABN AMRO, AkzoNobel, Arcadis, Cofely, Desso, DSM, Eneco, Essent, FMO, FrieslandCampina, IBM, ING, Interface, Nutreco, Philips, Port of Amsterdam en PwC. Deze bedrijven streven naar behoud van biodiversiteit en ecosystemen, terwijl zij tegelijkertijd de negatieve effecten van hun economische activiteiten minimaliseren en op duurzame wijze gebruikmaken van natuurlijk kapitaal.

\section{Financiële regelingen}

Het Nationaal Groenfonds is een organisatie die financiën beheert voor natuur en landschap voor zowel overheden, terreinbeherende organisaties als particuliere grondeigenaren. Daarnaast worden projecten gefinancierd waarbij natuur wordt gecombineerd met recreatie, duurzame energie, delfstofwinning en zorg.

Hieronder enkele voorbeelden van regelingen voor particulieren en bedrijven:

- De Regeling groenprojecten biedt fiscaal voordeel voor spaarders en beleggers die hun geld beleggen in groene projecten. Dit biedt vervolgens de banken de mogelijkheid om een relatief lage rente te vragen aan investeerders in groene projecten. Een investeerder heeft wel een groenverklaring nodig, en kan die krijgen wanneer geïnvesteerd wordt in nieuwe ontwikkelingen op het gebied van milieutechnologie of aansluit bij de hoofdpunten van het milieubeleid.

\footnotetext{
${ }^{9}$ De CoP bedrijven en biodiversiteit is in 2013 afgerond.
} 
- De provincies coördineren het Subsidiestelsel Natuur en Landschap (SNL), bedoeld voor terreinbeherende organisaties, particuliere grondeigenaren en collectieven van agrariërs. $\mathrm{Zij}$ kunnen een vergoeding krijgen voor het beheer en de inrichting van (agrarische) natuurgebieden en landschappen.

- Subsidie Kwaliteitsimpuls Natuur en Landschap (SKNL) is bedoeld voor ondernemers die investeren in natuurontwikkeling en -behoud. Bijvoorbeeld om grond geschikt te maken voor (agrarisch) natuurbeheer, of om de kwaliteit van een natuurgebied te verhogen.

- De Vergroeningsbetaling is bedoeld voor agrariërs die voorheen financiële steun van uit het Gemeenschappelijk Landbouw Beleid (GLB) ontvingen. Om in aanmerking te komen voor de basisbetaling moeten zij nu aan enkele voorwaarden voldoen, namelijk: gewasdiversificatie op bouwland; $5 \%$ van het bouwland als ecologisch aandachtsgebied; behoud van blijvend grasland.

\section{Onderzoek}

In het programma Natuurlijk Kapitaal Nederland (NKN) onderzoekt het Planbureau voor de Leefomgeving in opdracht van het ministerie van Economische Zaken waar natuur en economie elkaar kunnen versterken. Doel is het analyseren van natuurinclusieve oplossingen voor economische vraagstukken, en de succes- en faalfactoren om deze oplossingen te realiseren. Aansluitend worden adviezen geformuleerd voor investerings- en beleidsbeslissingen. Bijvoorbeeld over het wegnemen van belemmeringen in regelgeving, organisatievormen voor goede samenwerking, of kennis die ontwikkeld moet worden. NKN bouwt voort op het internationale initiatief The Economics of Ecosystems and Biodiversity (TEEB).

\subsection{Bijdragen vanuit het bedrijfsleven}

\section{Overzicht bijdragen}

De bijdragen vanuit het bedrijfsleven voor natuur nemen zeer uiteenlopende vormen aan. Ook de (financiële) bijdragen van de overheid verschillen nogal eens. Daarom een poging enige structuur aan te brengen.

Bijdragen aan natuur door ondernemers vindt deels plaats zonder (of met weinig) financiële steun van de overheid, maar daarnaast zijn er ook ondernemers die aanzienlijke financiële steun ontvangen. Met name waar het gaat om agrarisch natuurbeheer en particulier natuur- en bosbeheer bij bos- en landgoedeigenaren zijn er structurele financiële bijdragen van de overheid mee gemoeid. Op de andere as onderscheiden we bedrijven die individueel opereren tegenover geïnstitutionaliseerde netwerken.

Met de klok mee (figuur 3.2):

$\mathbf{1}^{\mathbf{e}} \boldsymbol{k w a r t : ~ I n d i v i d u e l e ~ b e d r i j v e n ~ d i e ~ z o n d e r ~ o f ~ m e t ~ b e p e r k t e ~ f i n a n c i e ̈ l e ~ s t e u n ~ v a n ~ d e ~ o v e r h e i d ~ z i c h ~}$ inzetten voor natuurontwikkeling. Beperkte financiële steun wil overigens niet zeggen dat deze bedrijven geen steun krijgen op andere wijze, zoals een tegemoetkoming met vergunningen e.d. De 'pareltjes' zoals vaak aangehaald in beleidsdocumenten zijn veelal dit type individuele bedrijven. Bijvoorbeeld Marnemoende; voorheen een melkvee- en varkenshouderij, dat is omgevormd tot een jachthaven en recreatieonderneming met ecologische visie. (zie Smits en Van der Heide, 2014).

$\mathbf{2}^{\mathbf{e}}$ kwart: Geïnstitutionaliseerde netwerken van bedrijven, waarin al dan niet ook NGO's en overheden in participeren, maar die geen structurele financiële bijdragen van de overheid ontvangen. Bijvoorbeeld de in paragraaf 3.3. genoemde Groene Tafels, en Community of Practice en de Platforms BEE en Leaders for Nature.

3e kwart: Geïnstitutionaliseerd netwerken van bedrijven met financiële contracten vanuit de overheid. Een voorbeeld hiervan zijn collectieven gericht op agrarisch natuurbeheer. Stichting Natuurrijk Limburg is een semi-professionele organisatie, opgezet door LLTB en Limburgs particulier grondbezit. Natuurrijk Limburg bundelt de krachten van boeren en particulieren in Limburg op het gebied van natuur- en landschapsbeheer.

$\mathbf{4}^{\mathbf{e}}$ kwart: Afzonderlijke bedrijven met financiële contracten met de overheid. Bijvoorbeeld Boeren voor Natuur: enkele bedrijven hebben langdurig contracten met de overheid in ruil voor het combineren van landbouw, natuur- en landschapsbeheer. 


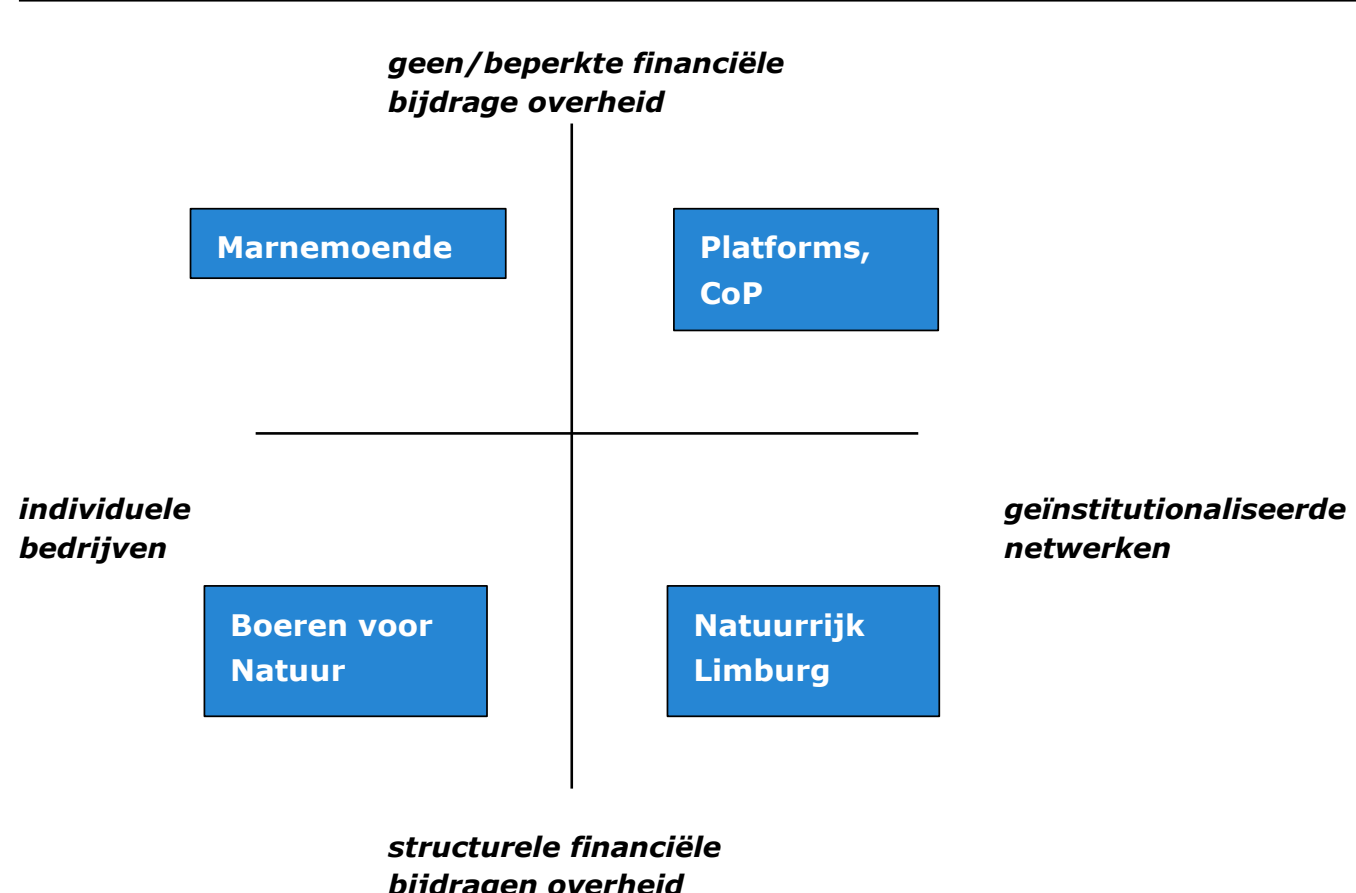

bijdragen overheid

Figuur 3.2: Verschillende initiatieven vanuit het bedrijfsleven gericht op natuurbeheer

In de bovenste helft van figuur 3.2 staan voorbeelden van natuurinclusief ondernemerschap waarvoor geen of beperkte financiële bijdragen van de overheid wordt ontvangen. Bijvoorbeeld de Green Deals vallen hieronder, waarbij steun van de overheid bij vergunningen e.d. wordt verleend, maar veelal geen structurele financiële steun. Voor agrarisch natuurbeheer wordt wel structurele financiële steun gegeven, en deze zien we dan ook in de onderste helft van figuur 3.2 terug.

Het schema in figuur 3.2 is niet de enige wijze waarop een verdeling gemaakt kan worden. Je kunt ook een onderscheid maken tussen bedrijven die een groen project financieren en bedrijven die groen daadwerkelijk integraal meenemen in hun business plan. Of bedrijven die groen direct verkopen (entreekaartje voor natuurgebied), of indirect (via imago etc.), of helemaal niet verkopen (maar een bijdrage leveren vanwege intrinsieke motivatie). Wij hebben gekozen voor de indeling zoals hierboven weergegeven om te laten zien dat bedrijven die bijdragen aan natuur soms geen financiële steun ontvangen van de overheid, maar soms ook wel. Ook wilde we laten zien dat er individuele bedrijven zijn die in groen investeren, maar dat er ook netwerken zijn. Vaak krijgen de individuele bedrijven zonder financiële steun ( $1^{\mathrm{e}}$ kwart van figuur 3.2) de meeste aandacht in rapporten (zie bijv. Breman et al., 2014; Wilschut en Koedoot, 2014).

\section{Overzicht motieven}

Er zijn verschillende motieven voor maatschappelijk verantwoord ondernemen (MVO), waaronder natuurbeheer door bedrijven. Hieronder gaan we uit van het werk van Van Luijk/Breman et al., en vullen dat aan met inzichten uit eigen werk.

In navolging van Van Luijk (2000) onderscheiden Breman et al. (2014) drie potentiële motieven: het loont, het hoort en het moet. In hoofdstuk 1 hebben we het begrip mainstreaming geïntroduceerd: wanneer er een breed draagvlak is dat het loont, hoort en moet spreken we van mainstreaming. Deze drie potentiële motieven vullen we hieronder aan op basis van Smits en Van der Heide (2014), zie de factoren genoemd achter de bullets.

Het eerste motief, genoemd door Breman et al. (2014), is dat MVO loont voor bedrijven, bijvoorbeeld vanwege risicobeheersing van grondstoffen. Factoren die van invloed zijn op het rendement zijn:

- Economische mogelijkheden (is een positieve factor: de ondernemer ziet kansen).

- Afhankelijkheid van ecosysteemdiensten (is een negatieve factor: risico dat essentiële ecosysteemdiensten worden aangetast). 
Het tweede motief is dat het hoort, bijvoorbeeld vanwege het intrinsieke waardenpatroon van de ondernemer. Factoren die van invloed zijn op het moraal zijn:

- Bedrijfskarakteristieken, met name persoonlijke factoren, maar ook de historie van het bedrijf.

Het derde motief is dat MVO moet, vanuit wet- en regelgeving, of afgedwongen door de publieke opinie. Factoren die daar invloed op zijn:

- Institutionele ontwikkelingen, waaronder wet- en regelgeving. Maar ook verleent de overheid subsidies en anderszins financiële bijdragen aan particulier natuurbeheer, faciliteert men initiatieven met Green Deals en Groene Tafels, en kan men met het aanbestedingsbeleid van de overheid bepaalde producten stimuleren.

- Maatschappelijke ontwikkelingen, waaronder publieke opinie. Ook kunnen groene NGO's en keyplayers in de keten een belangrijke rol spelen en veranderingen afdwingen.

Daarnaast wordt in Smits en Van der Heide (2014) nog het belang van kennisontwikkeling genoemd waardoor inzichten, prijzen en afhankelijkheden kunnen veranderen.

\subsection{Lessen voor dit onderzoek}

De traditionele rol van de overheid is sturend optreden en wetgeving verzorgen. In de Rijksnatuurvisie wordt daar een rol aan toegevoegd: het faciliteren van initiatieven uit de samenleving. Verschillende auteurs wijzen op het belang van een combinatie ven beide rollen. Hajer stelt dat burgers de eigen leefomgeving graag groen zien, maar tegelijkertijd door hun consumptiepatroon zorgen voor een toenemende milieudruk elders in de wereld. Selnes vult aan dat er een roep is naar vermaatschappelijking van het nationale natuurbeleid, maar tegelijkertijd meer overheidsingrijpen gevraagd wordt waar het gaat om internationale productie- en handelsketens. Mazzucato, Rifkin en anderen zien nog een derde rol voor de overheid: het opstellen van een masterplan om vandaaruit een vergaande ontwikkeling aan te sturen. Dit in samenspraak met het bedrijfsleven, maar gecoördineerd vanuit de overheid. En met budget.

Er zijn dus drie rollen voor de overheid: allereerst sturend en wetgevend, vervolgens ondersteunend voor maatschappelijke initiatieven, en tot slot leidend aan de hand van een masterplan. Zo'n masterplan kan een visie inhouden op natuurbehoud, maar bijvoorbeeld ook op duurzame energie, klimaatbestendigheid, en/of innovatie.

In de Rijksnatuurvisie is aandacht voor de wetgevende rol voor zover het gaat om internationale verplichtingen voor natuur. Vervolgens is er aandacht voor de ondersteunende rol bij maatschappelijke initiatieven. Maar de ambitie is groot: een natuurinclusieve economie. Hoort daar dan niet ook een leidende rol bij met een masterplan inclusief budget? 


\section{$4 \quad$ Voorbeelden van natuurinclusief handelen door bedrijven}

\subsection{Introductie}

In dit hoofdstuk richten we ons op die onderdelen van de landbouw, de recreatiesector en particuliere landgoedbeheer waar we de meeste mogelijkheden verwachten voor natuurinclusief handelen. We hebben grondintensieve sectoren geselecteerd die gebruik maken van natuur of van de natuurlijke processen die het ecosysteem levert. Niet toevallig komen de voorbeelden die in de Rijksnatuurvisie worden aangehaald grotendeels uit deze sectoren.

Binnen deze sectoren focussen we op die ondernemers waarvan we verwachten dat zij relatief veel met groen doen. Binnen de landbouw richten we ons op de biologische boeren. ${ }^{10} \mathrm{Bij}$ de recreatiesector focussen we op ondernemingen die 'afhankelijk zijn' van natuur op en rondom hun terrein. En we richten ons op particuliere landgoederen die natuur inzetten in hun verdienmodel.

Allereerst beschrijven we de sector en kijken wat de ontwikkelingen zijn de laatste decennia. Hiervoor gebruiken we tijdreeksen om de tendens te kunnen weergeven. Vervolgens beschrijven we hoe vanuit de verschillende sectoren aangekeken wordt tegen de Rijksnatuurvisie en het begrip natuurinclusief ondernemen. Dit doen we aan de hand van drie interviews. We hebben gesproken met Maaike Raaijmakers van Bionext, Ronnie van Woudenberg van de Federatie Particulier Grondbezit (FPG), en Ivo Gelsing van RECRON. We focussen nadrukkelijk niet op enkele mooie initiatieven, maar richten ons op de mogelijkheden tot mainstreaming.

\subsection{Biologische landbouw}

\subsubsection{Algemeen}

Tijdens het interbellum werd in Nederland volop geëxperimenteerd met verschillende kunstmeststoffen. Maar de introductie van kunstmest in de landbouw leidde ook tot kritiek, met name van de grondlegger van de antroposofie: Rudolf Steiner. In 1924 hield hij een lezing waarin hij stelde dat kunstmest de natuurlijke samenhang van de landbouw met zijn omgeving verstoorde. Hij pleitte voor het benutten van de krachten van de kosmos, om zo een vruchtbare bodem te bewerkstelligen. Meer specifiek: bij het zaaien, oogsten en verwerken van gewassen dienen boeren, aldus Steiner, rekening te houden met de stand van sterren en planeten. De methode ontwikkeld door Steiner wordt de biologisch-dynamische landbouw genoemd. ${ }^{11}$

In de jaren zestig nam de bezorgdheid omtrent het milieu toe, met name ook voor chemische bestrijdingsmiddelen in de landbouw zoals DDT. Hierdoor ontstond de ecologische landbouw, gericht op een landbouw zonder kunstmest en zonder chemische bestrijdingsmiddelen.

De biologische-dynamische en de ecologische landbouw worden inmiddels samen biologische landbouw genoemd. Sinds de jaren tachtig groeit de groep consumenten die zich richtte op gezond en milieubewust leven. Dit leidt tot extra vraag naar biologische producten.

\footnotetext{
${ }^{10}$ We hebben niet gekozen voor agrarisch natuurbeheer, omdat dit gefinancierd wordt door de overheid. We hebben voorbeelden gekozen die betaald worden door de markt.

${ }^{11}$ Uit de meeste recente cijfers blijkt dat het aantal boerenbedrijven met het keurmerk van Demeter (sinds 1928 het internationale biodynamische label) steeg van 113 in 2010 naar 129 in 2014. Het aantal hectares land dat biodynamisch wordt bewerkt, steeg tussen 2010 en 2014 met bijna een kwart, terwijl de totale hoeveelheid landbouwgrond in Nederland afneemt. De omzet van de biologisch-dynamische boeren steeg ook (van 12 miljoen euro in 2010 naar een geschatte 16 miljoen in 2014), maar vormt slechts een fractie van de 2 miljard euro die in de gehele biologische sector per jaar wordt omgezet (Trouw, 30 oktober 2015).
} 
In 2000 kwam de beleidsnota 'Een biologische markt te winnen' uit. De toenmalig minister van LNV Brinkhorst stelde in deze nota dat het Nederland zou sieren als in 2010 10\% van het landbouwareaal biologisch zou zijn. Die doelstelling bleek echter veel te ambitieus. In 2014 telt Nederland 49,3 duizend hectare biologische landbouwgrond. Daarmee wordt op 2,7 procent van het totale landbouwareaal biologisch geboerd (Figuur 4.1). ${ }^{12}$

\section{Areaal biologische landbouw}

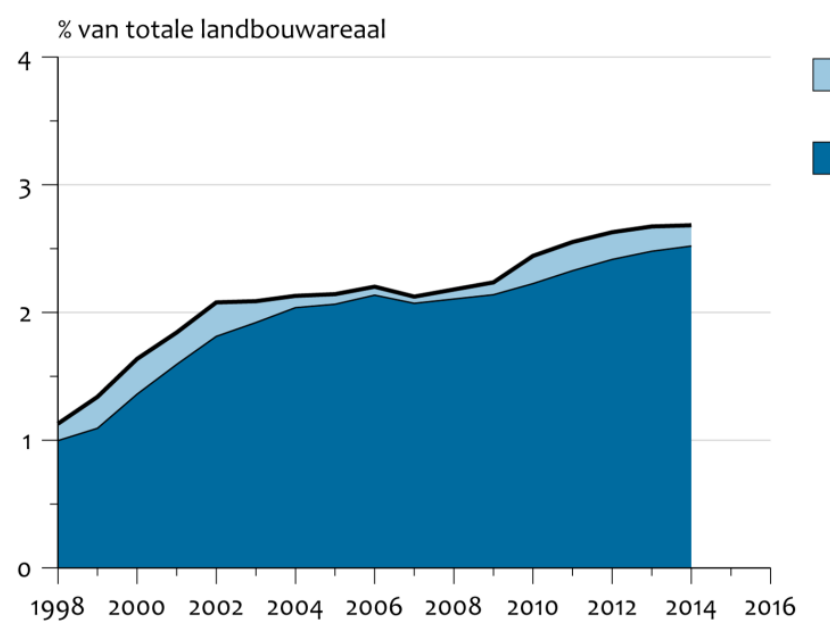

Bron: CBS.

In omschakeling naar biologisch

Gecertificeerd biologisch

Figuur 4.1: Omvang areaal biologische landbouw tussen 1998 en 2014 (overgenomen uit het Compendium voor de Leefomgeving, CBS et al., 2015)

In 2007 hebben de marktpartijen samen met de minister besloten de doelstelling van '10\% areaal in 2010' los te laten. In 2007 werden tevens steunmaatregelen geïntroduceerd voor de biologische landbouw, wat leidde tot groei. Het werd ook voor kleine bedrijven lonend om zich als biologisch landbouwbedrijf aan te melden bij Skal - de door de overheid aangewezen toezichthouder op de biologische productie in Nederland. In 2008 is een derde Convenant gesloten door 11 partijen, gericht op de marktontwikkeling van de biologische landbouw. De doelstelling werd dat het biologisch landbouwareaal per jaar met 5\% zou groeien, en dat de biologische sector zich zou ontwikkelen tot een sector die op eigen kracht verder kan. Maar ook de doelstelling van $5 \%$ per jaar is nooit gehaald. De groei trok vanaf 2009 wel verder aan om daarna toch weer af te zwakken. In 2011 stelde Staatssecretaris Bleker van Economische Zaken, Landbouw en Innovatie, tijdens het afsluitend congres van de Task Force Marktontwikkeling Biologische Landbouw, dat de biologische landbouw volwassen geworden was en dat het specifieke beleid voor deze sector daarom omgezet kon worden in regulier beleid. Sindsdien is er sprake van allereerst zeer beperkte stijging en vervolgens stagnatie van het aantal hectare biologische landbouwareaal.

In Nederland groeit het areaal biologisch landbouw langzamer dan in andere Europese landen. In Europa is het biologisch landbouwareaal tussen 2003 en 2010 met 55\% toegenomen. In de 'oude' lidstaten groeide het biologisch areaal met 5\% per jaar, terwijl in de 'nieuwe' lidstaten (die sinds 2004 deel uit maken van de EU) het biologisch areaal jaarlijks groeide met $13 \%$. In Nederland blijft de groei in deze periode steken op 2,7\%. Van het totale landbouwareaal in Europa is nu 5,4\% biologisch. In Nederland is het aandeel biologische landbouwgrond 2,7\% van het totaal (cijfers voor 2013). ${ }^{13}$

De Rabobank ziet kansen voor de biologische landbouw in de toekomst. De bank - die eind $19^{\mathrm{e}}$ eeuw is ontstaan in de landbouw en vandaag de dag wereldwijd wordt gezien als toonaangevende bank in

\footnotetext{
12 Cijfers op basis van het Compendium voor de Leefomgeving (CBS et al., 2015)

${ }^{13}$ Bionext, gebaseerd op Eurostat-data en CBS data. Site bezocht op 5-1-2016, zie:

http://www.bionext.nl/consument-zakelijk/biologische-landbouw-groeit-in-europa-nederland-blijft-achter
} 
food \& agri- stelt dat de vraag naar biologische producten in Nederland zich positief ontwikkelt. Daarbij zien ze een verschuiving in productie van meer traditionele naar meer commerciële biologische bedrijven. $^{14}$

Het verdienmodel van de biologische landbouw - dat wil zeggen, de wijze waarop de boer geld verdient -draait in de eerste plaats om de consument die een meerprijs betaalt voor biologische producten. ${ }^{15}$ Consumenten zijn een relatief hoge prijs te betalen voor biologische producten. Daarnaast vindt er (beperkte) stimulering plaats vanuit het Gemeenschappelijk Landbouwbeleid (GLB). Binnen het GLB is productiesteun losgelaten, en daarvoor in de plaats zijn vergroeningsmaatregelen gekomen. Gecertificeerde biologische bedrijven komen automatisch in aanmerking voor de premie voor vergroening. Daarbij mogen lidstaten ervoor kiezen om bij te dragen aan de omschakelingskosten van conventioneel naar biologisch landbouw. Nederland heeft daar echter niet voor gekozen.

"Voor de Nederlandse landbouw geldt dat biologische groenten en fruit (per kilogram eindproduct) beter voor het milieu zijn dan gangbare producten, als gelet wordt op biodiversiteit en gebruik van gewasbeschermingsmiddelen." ${ }^{16}$ Waarom zijn biologische boeren natuurvriendelijker dan gangbare boeren? Enigszins kort door de bocht geformuleerd: omdat in de biologische landbouw geen pesticiden gebruikt mogen worden is het beter voor het milieu, en een beter milieu pakt positief uit voor de natuurwaarde in een gebied. Ook doen biologische boeren meer aan vruchtwisseling en laten vaker stoppels en plantenresten achter op het land wat gunstig is voor de bodemstructuur en de biodiversiteit in de bodem.

Veel biologische bedrijven werken multifunctioneel: naast agrarische productie zijn ze meer dan gemiddeld betrokken bij zaken als agrarisch natuurbeheer. Bovendien stelt de Rabobank: "Veel biologische bedrijven maken gebruik van de ontwikkeling van natuur in de regio. De kwaliteit van het ruwvoer past redelijk in het rantsoen van biologische herkauwers. Daarnaast is het passend om het noodzakelijke areaal uit te breiden. Natuurontwikkeling past veelal goed in de filosofie van de ondernemer. Door goede afspraken te maken wordt er een vergoeding uitgekeerd voor het onderhoud en ontwikkeling van natuurgebieden." ${ }^{17}$

Let wel, het gaat om gemiddelden: er zijn altijd wel gangbare boeren te vinden die natuurvriendelijker werken dan sommige bioboeren. Bovendien kun je stellen dat de biologische landbouw een lagere opbrengst per hectare kent en dat daardoor meer grond nodig is voor landbouw waardoor minder grond overblijft voor natuur. Ook kent de biologische veehouderij een hogere $\mathrm{CO}_{2}$-uitstoot per producteenheid dan de gangbare veehouderij, omdat er meer dieren nodig zijn per eenheid product.

\subsubsection{Bionext ${ }^{18}$}

Bionext is de ketenorganisatie voor biologische landbouw en voeding, bestaande uit drie pijlers: biologische boeren en tuinders, handel en verwerking (zoals bakkers) en biologische winkelondernemers. Bionext behartigt de collectieve belangen van de biologische sector in eigen land en in Brussel. Maaike Raaijmakers is projectleider bij Bionext, met als belangrijkste thema's in haar portefeuille: natuur \& landschap, uitgangsmaterialen (pootgoed, zaaigoed) en gentechnologie. Voor haar is het belangrijk dat 'natuur' een integraal onderdeel wordt van het boerenbedrijf. Consumenten verwachten dat de biologische boer ook 'iets' met natuur doet, en het gebruikt in zijn/haar bedrijfsvoering. Bionext streeft ernaar om de bijdrage van biologische boeren aan natuur en landschap te vergroten, en dit te borgen (=certificeren) en in de markt te belonen.

\footnotetext{
${ }^{14}$ https://www.rabobankcijfersentrends.nl/index.cfm?action=branche\&branche=Biologische_veehouderij\&p=9 (site bezocht op 24-9-2015)

${ }^{15}$ Maar dat hoeft niet automatisch te betekenen dat de biologische boer nu zoveel meer krijgt in vergelijking tot de gangbare boer. De relatief hoge consumentenprijs voor biologische producten kan ook worden veroorzaakt door de te lage prijsstelling voor het gangbare voedsel (de stuntmelk, plofkip, etc.).

${ }^{16}$ http://www.milieucentraal.nl/voeding/biologisch/ (site bezocht op 14-1-2016)

${ }^{17}$ https://www.rabobankcijfersentrends.nl/index.cfm?action=branche\&branche=Biologische_veehouderij\&p=9 (site bezocht op 24-9-2015)

${ }^{18}$ Tekst van deze paragraaf is gebaseerd op het interview met Maaike Raaijmakers, Bionext, 3 december 2015.
} 
Raaijmakers constateert dat er een (groot) tekort op de markt is in biologische producten, zowel nationaal, als internationaal. Binnen de biologische sector zijn er zowel ideële biologische boeren als meer commercieel gerichte ondernemers. Voor beide type bedrijven is er een markt. Omschakeling vindt nog steeds plaats, veelal vanuit een bepaalde overtuiging van de boer. Het zelfcorrigerend vermogen van de sector is groot, en boeren willen al gauw verder in hun biologische bedrijfsvoering gaan dan de regelgeving vereist, aldus Raaijmakers.

\section{Biologische landbouw en natuur}

Raaijmakers verwacht dat biologische boeren vaker aan agrarisch natuurbeheer doen dan gangbare boeren, maar heeft geen cijfers om dit te onderbouwen. Relatief veel biologische bedrijven doen aan verbrede landbouw (zijn multifunctioneel). Dat betekent dat ze niet alleen producten verbouwen maar bijvoorbeeld ook actief zijn in agrarisch natuurbeheer, agrotoerisme en verkoop aan huis (vanwege risicospreiding en om inkomsten te garanderen). De openstelling voor publiek en de openheid van de bedrijfsvoering versterkt de belevingswaarde van 'biologisch' en de marktkansen voor verbredingsactiviteiten.

Biologische boeren hebben een positieve grondhouding richting natuur, en dat uit zich onder andere in een gezonde bodem en het inzetten van natuurlijke plaagbestrijders. Biologische boeren zijn meer afhankelijk van een gezonde bodem dan gangbare boeren; de basis voor hun bedrijfsvoering wordt gevormd door de bodem. Toch geldt ook voor biologische boeren uiteindelijk dat natuurbeheer ook financieel moet passen binnen de bedrijfsvoering.

Een mooi initiatief is de samenwerking van het Wereld Natuur Fonds (WNF) met FrieslandCampina en de Rabobank om de biodiversiteit op melkveebedrijven te verbeteren. ${ }^{19}$ Samen met melkveehouders verenigd in drie Friese Agrarische Natuurverenigingen bekijken genoemde partijen of en hoe een score-systeem voor biodiversiteit op melkveebedrijven kan worden geïntroduceerd.

Een ander initiatief is een project waarin onderzocht wordt wat de mogelijkheden zijn om extra natuur en biodiversiteit op biologische melkveebedrijven te verwaarden, nader wordt onderzocht (door vier melkverwerkers). Voor een melkverwerker wordt een dergelijke omschakeling interessant wanneer, zeg, $80 \%$ van de boeren die bij hem/haar melk aanleveren op deze natuurvriendelijke toer gaan. ${ }^{20}$ Een ander fenomeen zijn de Natuurboeren: zij produceren primair natuur en doen landbouw erbij. Ten minste $25 \%$ van hun grond bestaat uit natuurgrond en/of landschapselementen. Ze werken nauw samen met ketenpartijen en terreinbeheerders van bijvoorbeeld Staatsbosbeheer, Natuurmonumenten, provinciale Landschappen en soms particulieren. ${ }^{21}$

De biologische sector staat voor de uitdaging om continu onderscheidend te blijven ten opzichte van de reguliere sectoren, die ook verduurzamen. Met andere woorden, de afstand tussen gangbare landbouw en biologische landbouw wordt minder als de sector niet verder verduurzaamt. Ook om de meerprijs voor biologische producten vast te blijven houden, moet de biologische sector zich verder ontwikkelen. Voor deze 'doorontwikkeling' noemt Maaike een paar mogelijkheden:

- Geef een bepaalde mate van vrijheid aan boeren voor de invulling van natuur op hun bedrijf , bijvoorbeeld als het gaat om het verplaatsen van een kruidenrand. Geef ze zulke speelruimte / flexibiliteit en leg niet alles vast in strikte regels.

- Reken af op resultaat, dus bijvoorbeeld op het uiteindelijk aantal gruttopaartjes op een boerenland, in plaats van dat je de boeren voorschrijft wanneer ze wel en niet mogen maaien.

Raaijmakers noemde nog het onderscheid tussen het biologische balansmodel versus het gangbare controle model. Dit laatste model is gebaseerd op een zekere mate van angst, namelijk angst dat het niet zo gaat zoals de boer wil. Vandaar dat hij bijvoorbeeld gif spuit om zelf controle te houden over plagen.

\footnotetext{
${ }^{19}$ Dit initiatief is overigens niet specifiek gericht op de biologische landbouw. Er wordt wel samengewerkt met het Louis Bolk Instituut. Zie ook Erisman et al. (2014).

${ }^{20}$ Zie Meeusen et al. (2015). Er is overigens een ander, vergelijkbaar, initiatief die niet specifiek gericht is op de biologische landbouw, genaamd Blief.

${ }^{21}$ Voor meer informatie, zie http://www.natuurboeren.nl/.
} 


\section{De Rijksnatuurvisie en overig beleid}

De overheid pleit, onder andere in de Rijksnatuurvisie, voor meer verantwoordelijkheid voor natuurbehoud bij ondernemers. Maar de realiteit is dat overheidsingrijpen de laatste jaren juist een tegenovergesteld effect heeft. Raaijmakers noemt een aantal voorbeelden.

Van de afschaffing van het melkquotum ondervinden vooral extensieve boeren de nodige hinder doordat de melkprijs sterk daalt. Terwijl het overheidsbeleid er min of meer op gericht is om de landbouw te vergroenen en te verduurzamen, is het gevolg van de afschaffing dat er geïntensiveerd wordt om voldoende geld te verdienen. Voor extensieve boeren die niet willen intensiveren en willen overschakelen naar de biologische landbouw vormt toegang tot (nieuwe) gronden een obstakel. Veel gangbare boeren hebben grond nodig als mestplaatsingsruimte en zijn bereid daar heel hoge prijzen voor te betalen. Biologische boeren kunnen deze truc niet uithalen. De openbare aanbesteding van grond drijft de prijs nog verder op.

Vroeger waren er omschakelsubsidies waarmee gangbare boeren makkelijker de overstap konden maken naar een biologische bedrijfsvoering. Maar deze subsidies zijn er niet meer. Feit blijft dat omschakeling veel tijd en investeringen kost en dat de banken nog altijd niet bereid zijn om hiervoor de benodigde leningen te verschaffen. Als voorbeeld werd de sierteelt / bollenteelt genoemd, waar door gangbare landbouw de bodem vaak dood is gespoten.

Opnieuw kwamen we bij het onderwerp grond uit - de sleutelfactor voor biologisch boeren. Op provinciaal niveau kan via ruimtelijk ordeningsbeleid gestuurd worden: daar waar kansen liggen voor biologische landbouw, kunnen extra eisen gesteld worden aan de pachters (bijvoorbeeld: meer natuurwaarde realiseren, minder agrarische productie). Zo kan de provincie in bufferzones van natuurgebieden 'bovenwettelijke' eisen stellen, ook aan natuur. Biologische boeren zijn bij uitstek de ondernemers die hier het beste op kunnen inspelen. Idem dito voor waterwingebieden: ook hier kan de provincie eisen stellen, en zo mogelijkheden bieden voor biologische boeren. Verder kan er door de provincie een stimuleringsbeleid gevoerd worden voor het belonen van natuurvriendelijke landbouw.

\subsection{Particulier landgoedbezit}

\subsubsection{Algemeen}

Een landgoed omvat meerdere hectares, met tuinen, bos en/of landbouwareaal. Op een landgoed staat een prestigieus gebouw, bijvoorbeeld een landhuis, buitenplaats, grote boerderij, kerk of kasteel. Landgoederen en natuur zijn nauw met elkaar verweven. Dat was vroeger al zo - door de grote afwisseling van bos, weide en akkers met tussenliggende houtwallen kenden veel landgoederen vroeger al hoge natuurwaarden - en dat is vandaag de dag nog steeds zo. Kortom, veel natuur heeft Nederland te danken aan particulier landgoedbezit.

Al vóór de $18^{\mathrm{e}}$ eeuw begonnen particulieren met de aanleg van buitenplaatsen langs de Vecht en in de strook achter de duinen tussen Wassenaar en Bloemendaal. Met inkomsten uit met name agrarische pacht, jachtrechten en houtproductie kan een (groot) deel van deze buitenplaatsen zichzelf volledig bedruipen. Zo ontstonden de multifunctionele landgoederen die we nu nog kennen (Kamerbeek, 2012). Veel van deze landgoederen hebben grondposities op cruciale plekken in het Natuurnetwerk Nederland, aldus Vijn \& Borgstein (2014).

Het behoud van particulier landgoedbezit in Nederland hangt sterk samen met de Natuurschoonwet. ${ }^{22}$ Toen na de eerste wereldoorlog de belastingen werden verhoogd, met name ook de vermogensbelasting en successierechten, werd het steeds moeilijker om landgoederen financieel gezond te houden. Dit had als gevolg dat veel landgoederen met bijbehorend bos dreigden te worden verkocht om er vervolgens een andere lucratieve bestemming aan te geven, zoals villawijken. Om deze ontwikkeling te stoppen werd in 1928 de Natuurschoonwet aangenomen. In deze Natuurschoonwet

${ }^{22}$ Deze paragraaf is grotendeels gebaseerd op: W. Verstegen (2012), Vrije Wandeling, VU 
werd bepaald dat de belasting bij het bepalen van de waarde van een landgoed uitgaat van de bestemmingswaarde in plaats van de verkoopwaarde. Over het algemeen geldt dat de bestemmingswaarde $50 \%$ tot $75 \%$ bedraagt van de verkoopwaarde. Daarmee leidde deze wet tot een aanzienlijke belastingverlaging. Voorwaarde is echter wel dat een landgoed minstens 5 hectare groot is en voor minstens 30\% uit bos en/of natuur bestaat. En heel belangrijk, een landgoed moet voor minstens 25 jaar als landgoed beheerd worden. Er gelden strenge regels voor het kappen van bomen. Extra belastingvoordeel kan verkregen worden wanneer een landgoed opengesteld wordt voor het publiek.

De Natuurschoonwet had het gewenste effect. Verstegen geeft de volgende cijfers: in de jaren dertig en veertig van de vorige eeuw kwam circa 100.000 hectare landgoed onder de Natuurschoonwet te vallen. In 1951 vielen 667 landgoederen onder de wet, en daarvan waren er 493 opengesteld voor het publiek (Tabel 4.1). ${ }^{23}$

\section{Tabel 4.1}

Aantal hectare onder de Natuurschoonwet in verscheidene peiljaren 1952-2007

\begin{tabular}{lrr} 
Jaar & Aantal ha & $1952=1.00$ \\
\hline 1952 & 106.000 & 1.00 \\
\hline 1961 & 105.126 & 1.00 \\
\hline 1975 & 105.000 & 1.00 \\
\hline 1989 & 102.893 & 0.98 \\
\hline 1994 & 95.000 & 0.90 \\
\hline 2004 & 88.713 & 0.84 \\
\hline 2007 & 117.456 & 1.11 \\
\hline
\end{tabular}

Bron: Verstegen, 2012, refererend aan een zevental bronnen

Na 1975 neemt het aantal hectares landgoederen af. Dit hoeft echter niet te betekenen dat er landgoederen opgeheven zijn. Verscheidenen landgoederen zijn van privébezit overgegaan naar stichtingen en natuurbeheerorganisaties. Voor hen geldt andere wetgeving en is de Natuurschoonwet minder aantrekkelijk. Er zijn dus landgoederen die niet langer onder de Natuurschoonwet vallen, maar wel zijn blijven bestaan.

Na 1989 zien we een verdere daling van het aantal hectares onder de Natuurschoonwet. Dat komt door een wetwijziging in 1989 waarbij een aantal zaken werden geherdefinieerd: de minimale omvang van een landgoed, de 30\% regeling omtrent de omvang van bos en/of natuur, het maximaal toegestane deel landbouwgrond, en de aanwezigheid van wandelpaden.

In 2001 en 2007 is de Natuurschoonwet opnieuw aangepast. In 2001 is de regeling Nieuwe Landgoederen ingegaan. Er mag een landhuis gebouwd worden wanneer dit gecombineerd wordt met natuur die minstens 25 jaar intact gelaten moet worden. In 2007 is de definitie van natuurterreinen verruimd, met name zodat nieuwe en nog te ontwikkelen natuur aangemerkt kan worden als landgoed. Ook mogen nu natuurlijke graslanden meegerekend worden als natuur.

Om de cijfers uit tabel 4.1 in perspectief te zetten geven we het aantal hectares natuur in bezit van Staatsbosbeheer en overige natuurbeheerorganisaties. Staatsbosbeheer bezit circa 264.000 hectare bos en natuur. Natuurmonumenten en de Provinciale Landschappen bezitten samen meer dan 166.000 hectare natuurgebied in Nederland. Overige particuliere verenigingen of stichtingen voegen daar nog 46.000 hectares aan toe. Het ministerie van Defensie bezit 30.000 hectare natuurgebied. Delen van de duinen worden als natuurgebied beheerd door een waterleidingbedrijf, zoals de Gemeentewaterleidingen Amsterdam (3.500 hectare) en PWN Waterleidingbedrijf Noord-Holland (7.300 hectare) (Silvis en Voskuilen, 2014).

\footnotetext{
${ }^{23}$ Verstegen (2012, blz. 7). Afgezien van Verstegen hebben we geen tijdreeksen gevonden. Waarschijnlijk komt dit omdat verschillende definities gebruikt worden van een landgoed, wat een vergelijking over de jaren bemoeilijkt. De grootste verschuivingen zien we bovendien door verandering in regelingen - en daarmee in feite door verandering van de definitie van wat een landgoed is. Dit zien we ook terug bij Verstegen.
} 
Sinds twee decennia stimuleert de overheid de ontwikkeling van nieuwe landgoederen. Echter, de resultaten blijven achter bij de verwachting. Vader et al. (2011) beschrijven een aantal knelpunten. Zo hebben gemeenten vaak te weinig ervaring en parate kennis op het gebied van nieuwe landgoederen. Het doorlopen van procedures rond bestemmingsplannen kan veel tijd vragen. Ook kan vanuit de omgeving gemakkelijk weerstand ontstaan tegen de plannen. Tot slot is de exploitatie van nieuwe landgoederen vaak moeilijk rond te krijgen.

Er zijn subsidieregelingen waar landgoedeigenaren gebruik van kunnen maken, zoals subsidies voor incidentele maatregelen, bijvoorbeeld herstel van landschapselementen, of voor een nieuw te ontwikkelen landgoed. Voor een tegemoetkoming in langdurige, doorlopende kosten voor beheer van bos- en natuurterreinen kan men terecht bij de regeling Subsidie Natuur- en Landschapsbeheer (SNL). Echter, de bijdrage uit deze SNL-regeling zijn de laatste jaren omlaag gegaan. Daarom is het voor landgoedeigenaren nog belangrijker geworden om extra inkomensbronnen te genereren.

De subsidieregelingen staan dus onder druk. De Federatie Particulier Grondbezit (FPG) heeft zich ten doel gesteld de zelfredzaamheid en het verdienvermogen van landgoederen te vergroten. De Rijksnatuurvisie voorziet erin dat ondernemers meer mogelijkheden geboden krijgen om zich in te zetten voor natuurbeheer. FPG ziet landgoederen als ideale mogelijkheid om hieraan te voldoen. En de Rijksnatuurvisie biedt, aldus FPG, kansen voor nieuwe verdienmodellen voor landgoedeigenaren. (De Bont \& Prins, 2014)

Maar een verdienmodel voor een landgoed is maatwerk. "Landgoederen hebben behoefte aan nieuwe verdienmodellen die aansluiten bij de specifieke kenmerken van hun landgoed" (Vijn et al., 2015. Er zijn geen 'one size fit all' mogelijkheden. Er zijn inmiddels meer studies verschenen met voorbeelden van verdienmodellen voor landgoedeigenaren. Vijn et al. richten zich specifiek op landgoedeigenaren met pachters. Andere voorbeelden van nieuwe succesvolle verdienmodellen op landgoederen zijn onder andere te vinden bij Kamerbeek (2012; 2015).

\subsubsection{Federatie Particulier Grondbezit ${ }^{24}$}

De Federatie Particulier Grondbezit (FPG) is een belangenorganisatie voor particuliere grondeigenaren: landbouwgrond (verpacht of in eigen gebruik), bos- en natuurterreinen, oude en nieuwe landgoederen, en terreinen met een recreatieve functie. De Federatie kent ca. 1.600 leden die in totaal bijna 200.000 hectare grond bezitten. Wat betreft historische landgoederen is 75 tot $80 \%$ in bezit van particulieren (met een redelijke constante omvang van grofweg $125.000-130.000$ hectare). De rest is in handen van terreinbeherende organisaties (TBO's). Bij FPG loopt het voor natuur uiteen van donkergroen tot lichtgroen. Maar ook de gebouwen zijn belangrijk.

\section{Economische dragers van landgoederen}

Meer dan voorheen is natuur een economische drager / drijfveer voor nieuwe landgoederen.

Traditionele economische dragers van landgoederen zijn:

- Hout/bos: maar dat rendeert matig.

- Pacht: maar dat is sterk gereguleerd.

En dan zijn er nog de gebouwen die ingezet kunnen worden voor het verdienmodel. Traditioneel was een huis van allure de drijfveer, maar dat is nu niet meer actueel. Een huis van allure als economische drager is tijdelijk weinig interessant. Het wachten is op het aantrekken van de markt voor het duurdere segment.

Belangrijk voor het vinden van economische dragers waarmee landgoederen duurzaam in stand gehouden kunnen worden, is ondernemerschap (met bijbehorende passie, visie en een businessplan). Het gaat bovendien vaak om maatwerk - er is geen 'one-size-fits-all' aanpak. Tegelijkertijd is het een feit dat veel landgoederen (erg) klein zijn, met weinig mogelijkheden en kansen voor de ontwikkeling van economische drivers.

\footnotetext{
${ }^{24}$ Tekst van deze paragraaf is gebaseerd op het interview met Ronnie van Woudenberg, FPG, 29 november 2015.
} 


\section{Toekomstvisie van de FPG}

De natuurontwikkeling op landbouwgronden behorend tot landgoederen loopt terug. De ontwikkeling van natuur op landbouwbedrijven is afhankelijk van de marktontwikkeling van agrarische producten. Er zijn nog steeds veel stoppers met hun bedrijven die in een landschappelijk en natuuraantrekkelijk gebied liggen. Voor deze initiatiefnemers is het NSW-waardig ${ }^{25}$ maken van hun bezit door aanleg van natuur een optie.

Er komen door Staatsbosbeheer (SBB) en het Bureau Beheer Landbouwgronden (BBL) ${ }^{26}$ af te stoten terreinen (in de regel van bescheiden omvang) op de markt. Er gaan stemmen om SBB-gebieden/ terreinen in een BV-constructie op de markt te brengen, waarvan de aandelen door burgers en investeerders kunnen worden gekocht.

FPG vindt gelijkberechtiging belangrijk, er moet meer marktwerking komen in natuur en landschap. Dit zorgt voor meer 'beweging', en minder starheid. Terreinbeherende organisaties (TBO's) hadden een voorkeurpositie bij de aankoop van grond. Elk bod van particulieren werd overruled door de overheid / TBO's. Nu zijn er afspraken gemaakt in IPO-verband ${ }^{27}$. Wanneer er terreinen (BBLgronden) op de markt komen, dan vindt er een openbare aanbesteding plaats. Transparantie is belangrijk. Wel moeten er goede afspraken gemaakt worden over beheer en toegankelijkheid van het gebied.

FPG wil graag de investeringsmogelijkheden vergroten voor particulieren die willen investeren in een landgoed. Maar tegelijkertijd moet de natuur voldoende beschermd worden. En om een landgoed voor de lange termijn te behouden, is een goed verdienmodel noodzakelijk. Het is steeds een afweging: natuurbeheer combineren met een verdienmodel. Soms leidt dit tot een spagaat, want kies je nu voor natuur- en landschapsbescherming of juist voor ontwikkelingsmogelijkheden? Daarbij is van belang dat gemeenten er op de juiste wijze bij worden betrokken. Tegelijkertijd vragen landgoederen om een integrale visie (over landbouw, vastgoed, natuur, ...), terwijl veel wet- en regelgeving sectoraal is. Dat maakt de dingen niet altijd even eenvoudig.

FPG is van mening dat de overheid meer ruimte moet bieden voor nieuwe landgoederen. Men dient voorzichtig te zijn met de aankoop van grond voor TBO's via subsidies. Eerst grond transparant aanbieden op de markt, wel met voorwaarden voor natuurbeheer/natuurbehoud (zodat projectontwikkelaars die louter op winst uit zijn, 'eruit gefilterd' worden). En in aanbestedingsvoorwaarden bijvoorbeeld opnemen dat het openstellen van het terrein een verplichting is.

FPG stelt voor dat er meer grond op de markt wordt gebracht. SBB zou bijvoorbeeld wat grond op de markt kunnen brengen, en zo geld genereren wat elders ingezet kan worden. Daarmee krijg je een meer dynamisch, meer flexibel systeem, in de rollen van beheerders. Samenwerking tussen particulieren en TBO's kan ook verder gestimuleerd worden.

\section{Visie ten aanzien van Rijksnatuurwet}

De Rijksnatuurvisie wordt door FPG omarmd. Echter, de visie uit de Rijksnatuurvisie is onvoldoende terug te vinden in de natuurwetgeving. In de wetgeving is het vertrouwen in particuliere natuurbeheerders nog beperkt. Kortom, de ideeën die zijn vastgelegd in de natuurvisie zijn goed maar het schort nog aan de uitwerking. Ook is er nog teveel bureaucratie. Door de decentralisatie van natuurbeheer naar de provincie is er een bestuurslaag bijgekomen. Naast het Rijk, nu ook de provincie. Voor zowel de overheid als voor de particuliere grondeigenaar betekent dit een administratieve lastenverzwaring.

\footnotetext{
${ }^{25}$ NSW staat voor Natuurschoonwet.

${ }^{26}$ In de Boerderij, 97-no. 39, 2012, is een artikel verschenen onder het kopje: Duizenden hectares in de verkoop.

27 IPO staat voor Interprovinciaal Overleg.
} 


\subsection{Recreatie in de natur}

\subsubsection{Algemeen}

In de negentiende - en met name twintigste eeuw - kwam meer ruimte voor nieuwe vormen van vrijetijdsbesteding door de groeiende welvaart en door een kortere werkweek (meer vrije tijd). Begin twintigste eeuw kwam de regeling dat het loon werd doorbetaald tijdens enkele vastgestelde vakantiedagen. De werkweek werd teruggebracht tot 45 uur. De vijfdaagse werkweek van 40 uur kwam pas in 1960: dat was het begin van de vrije zaterdag. In 1966 gevolgd door de extra vakantietoeslag: werknemers kregen niet alleen hun vijfentwintig vakantiedagen doorbetaald, maar kregen extra geld om met vakantie te gaan (Vink, 2015). Ook de toegenomen mobiliteit, door uitbreiding van het openbaar vervoer en door de opkomst van het autobezit, heeft een grote bijdrage geleverd aan de opkomst van recreatie.

In de jaren tien en twintig van de vorige eeuw werd het bij de elite populair om uitstapjes te maken naar het park of het strand. In 1928 werden twee parken geopend: het Kralingerhout in Rotterdam en het Amsterdamse bos. De parken en de stranden werden een plek om te flaneren voor de rijkere bovenlaag van de steden.

Na de Tweede Wereldoorlog nam de vraag naar recreatie verder toe dankzij een stijgende welvaart, meer vrije tijd en een toename van de bevolkingsdichtheid. Daarmee steeg ook de behoefte aan openbare recreatieterreinen. Recreatie werd steeds meer gezien als een publiek belang, en het beleid gericht op recreatie nam toe. Met name vanaf de jaren zestig en zeventig worden steeds meer recreatievoorzieningen getroffen. In 1992 komt de nota Kiezen voor recreatie uit (LNV, 1992), een beleidsnota gericht op openluchtrecreatie. Naast de - door de overheid aangelegde - openbare recreatievoorzieningen is er ook een toenemend aanbod van de private sector. Voor de private recreatiesector hebben lagere overheden een sturingsmogelijkheid via bestemmingsplannen.

In het voorjaar van 2013 heeft minister Kamp de gastvrijheidseconomie uitgenodigd om met een visie en met plannen te komen. Om dat te bereiken gaf hij aan de topsector-aanpak te willen toepassen. Een aanpak waarin samenwerking tussen bedrijfsleven, overheden en kennisinstellingen centraal staat. Gastvrij Nederland - de Nationale Raad voor Toerisme, Recreatie, Horeca en Vrije Tijd nam het initiatief over en in lijn met de topsectoren-aanpak werd een topteam samengesteld, bestaande uit ondernemers en representanten van de kennisinstellingen en de overheid. Inmiddels ligt er een Startdocument sectorvisie - Fase I. Veel parels, nu nog een ketting. ${ }^{28}$ Het verder verbeteren van de relatie recreatie en natuur wordt genoemd als één van de acht nog nader uit te werken actiepunten.

Recentelijk zet de Rijksoverheid ook green deals in om recreatieondernemers te stimuleren nieuwe manieren te bedenken om in natuur te investeren. Er zijn zes green deals afgesloten met de recreatiesector, met als doel te laten zien dat economische groei kan samengaan met natuur. ${ }^{29}$

Een interessant initiatief in dit kader is Krugerpark.nl. Het idee, uitgewerkt door het InnovatieNetwerk, is om 200.000 hectare natuurgebied subsidievrij te beheren. In Nederland mag je overdag recreëren in natuurgebieden, maar niet 's nachts. Hier wil men verandering in brengen. Daartoe worden resorts met lodges gebouwd in natuurgebieden (bijv. Oostvaardersplassen of Weerribben-Wieden). De toeristen mogen dan overnachten in deze gebieden, en betalen voor deze beleving. Deze inkomsten worden gebruikt om het beheer van het gebied te bekostigen (STIRR, 2015).

\footnotetext{
${ }^{28}$ Zie http://www.gastvrij-nederland.nl/visie/Startdocument-Gastvrijheidseconomie.pdf (site bezocht op 17 december 2015)

${ }^{29}$ Zie http://www.rijksoverheid.nl/onderwerpen/toerisme-en-recreatie/toerismebeleid-versterking-toeristische-sector (site bezocht op 17 december 2015)
} 
Wanneer naar overnachten in de natuur wordt gekeken dan blijkt dat overnachten in hotels en bungalows een groeisector is, maar dat het kamperen in Nederland onder druk staat. ${ }^{30}$ Een klein deel van de kampeerbedrijven (meestal de meer luxe kampeerterreinen) kan zich goed redden. De grote meerderheid komt niet mee en verliest terrein. De groei van het kamperen in Nederland en al helemaal van het tentkamperen is eruit (NRITmedia/NBTC/CELTH, 2014). Er zijn echter lichte tekenen van herstel omdat de verkoop van caravans sinds jaren weer is toegenomen. De terugval van kamperen geldt niet voor kamperen op kleinschalige, meer op natuur en de agrarische sector gerichte kampeerterreinen. Figuur 4.2 laat de groei zien van het aantal overnachtingen op natuurkampeerterreinen.

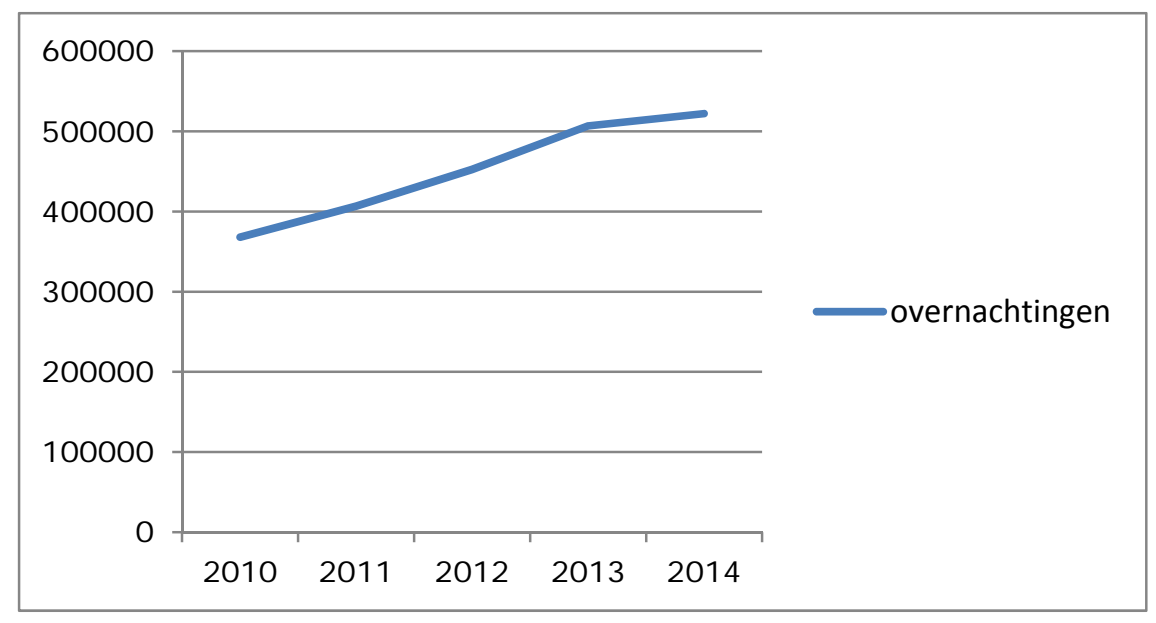

Figuur 4.2: Overnachtingen (per jaar) op natuurkampeerterreinen (bron: Stichting Natuurkampeerterreinen)

Overnachtingen op natuurkampeerterreinen laten een stijgende lijn zien, maar ook concepten als FarmCamps en het Betere Boerenbed doen het goed. De Stichting Vrije Recreatie (SVR) laat al jaren groeicijfers zien van het 'kamperen bij de boer'. Toch blijft de omvang van de overnachtingen van deze bedrijven beperkt op het totaal en kan het gezien worden als een (succesvolle) nichemarkt.

Er worden vijf recreatiemotieven onderkend door Goossen \& De Boer (2008), namelijk: Gezelligheid, Even tussen uit, Interesse, Opgaan in andere wereld en Uitdaging. Opgaan in de natuur wint aan populariteit, maar wordt toch nog relatief weinig genoemd als belangrijkste motivatie. Het vaakst wordt genoemd Gezelligheid, gevolgd door het motief Even tussen uit. Wel blijkt dat het motief Gezelligheid iets aan populariteit moet toegeven, evenals het motief Uitdaging (Figuur 4.3).

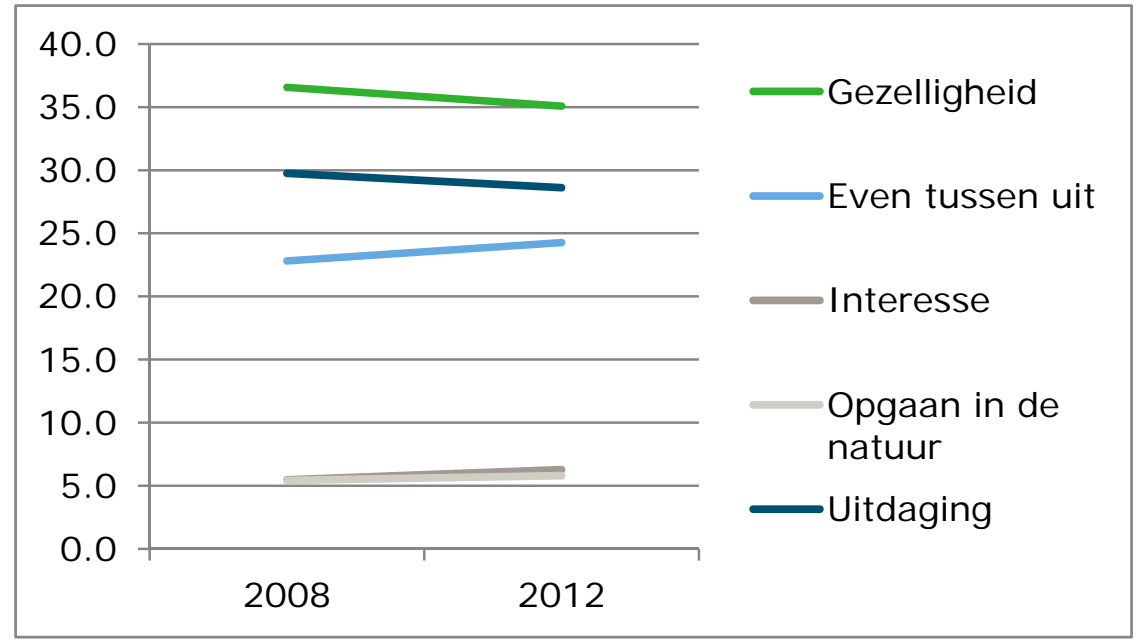

Figuur 4.3: Ontwikkeling in type recreatiemotief

\footnotetext{
${ }^{30}$ Het vervolg van deze paragraaf is grotendeels gebaseerd op een interne notitie van M. Goossen, Alterra Wageningen UR, 2015.
} 
De Rabobank stelt dat vakantieparken in Nederland moeilijke tijden beleven. De markt is verzadigd en veel ondernemers hebben geen geld om te investeren. Er is nog wel een groeiende vraag naar luxe (zoals glamping-tenten), bijzondere accommodaties (zoals een boomhut), en vakantieparken met een scala aan in- en outdoor-activiteiten. Maar ook zijn er mogelijkheden voor een camping met een bijzondere ligging in de natuur. "Zo is Strandcamping Groede in Zeeuws-Vlaanderen schitterend gelegen in het duingebied. De ondernemers investeerden samen met de lokale overheid in verdere ontwikkeling van de omgeving tot een uniek natuurgebied, wat de authenticiteit van hun product verder versterkte" (Rabobank, 2015).

Het verdienmodel voor de recreatiesector is: de consument betaalt voor het verblijf. De groenvoorziening komt echter grotendeels tot stand via de publieke sector. Denk aan een camping op de Veluwe. Dat neemt echter niet weg dat ook recreatieondernemers investeren in de natuur op en rondom hun terreinen. Hierbij is volgens Goossen (2013) wel een kanttekening op zijn plaats: "Recreatieondernemers investeren vooral in groen op het eigen terrein of via aankoop van gronden voor compensatie in geval van uitbreiding van het eigen terrein voor bedrijfsmatige doeleinden. Er liggen meestal economische motieven aan ten grondslag en het gaat om de vraag wat de investering het bedrijf direct of indirect opbrengt."

De relatie recreatie en natuur kan als volgt weergegeven worden (figuur 4.4):

\section{Biodiversiteit}

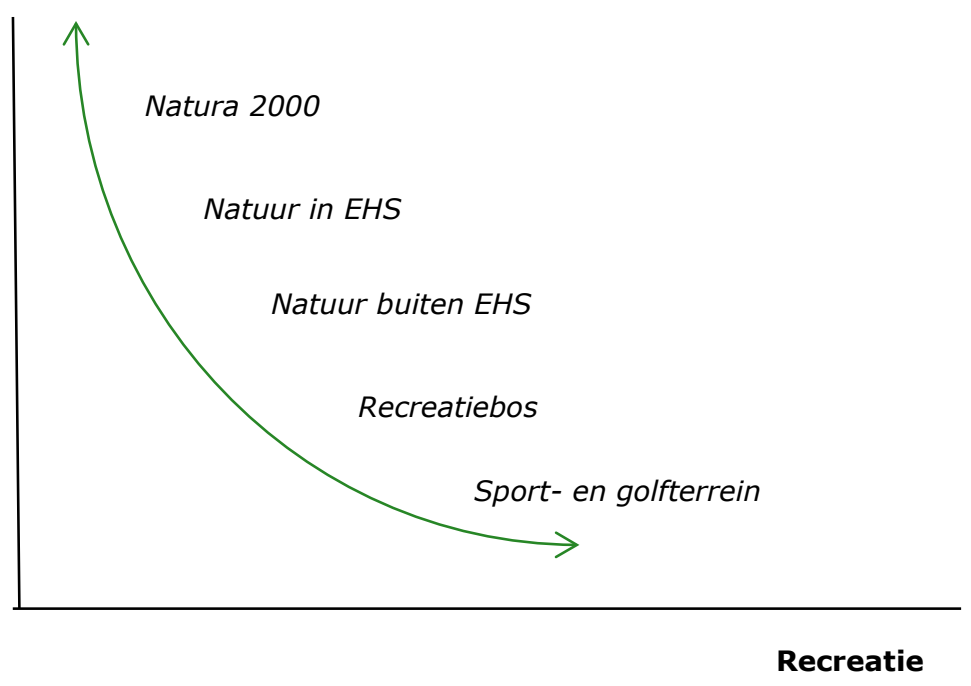

Figuur 4.4: Relatie natuur en recreatie. Bron: MNP et al. (2006; blz. 421).

Figuur 4.4 verbeeldt de relatie tussen zogenaamde groenblauwe recreatie en biodiversiteit. Voorbeelden van groenblauwe recreatie zijn: wandelen, fietsen, zwemmen en waterrecreatie. Onder groenblauwe recreatie valt dus niet cultuurgerichte recreatie, recreatief winkelen of het bezoeken van een pretpark. Het belang van groenblauwe recreatie voor het behoud van biodiversiteit loopt uiteen van licht groen (gebruik maken van sport- en golfterreinen) tot donkergroen (wandelen in Natura 2000 gebieden).

\subsubsection{RECRON ${ }^{31}$}

RECRON - de Vereniging van Recreatieondernemers Nederland opgericht in 1969 - streeft naar een optimaal ondernemersklimaat in de recreatiebranche en behartigt de collectieve en individuele belangen van haar ruim 2000 leden. $86 \%$ van de werknemers in de branche is werkzaam bij RECRON-

\footnotetext{
${ }^{31}$ Tekst van deze paragraaf is gebaseerd op het interview met Ivo Gelsing, RECRON, 29 november 2015. Ivo Gelsing is regiomanager Gelderland en nationale dossierhouder natuur.
} 
leden. De organisatie RECRON vertegenwoordigt circa $85 \%$ van de omzet binnen de recreatiebranche. RECRON kent zes bedrijfsgroepen, namelijk (i) Kampeer- en Bungalowbedrijven; (ii) Groepsaccommodaties; (iii) Dagrecreatie; (iv) Buitensport (VeBON); (v) Sauna's en Thermen en (vi) Zwembaden. RECRON werkt op het onderwerp 'recreatie en natuur' samen met collega-organisaties in de 'Regiegroep Recreatie \& Natuur'.

\section{Recreatie en natuur}

Recreatieondernemers willen zich best laten verleiden om dingen met en voor de natuur te doen, maar wel onder de voorwaarde dat er vervolgens geen belemmerende wet- en regelgeving optreedt. Een mooi voorbeeld is NatuurVakantiepark Waterdunen. ${ }^{32}$ Eerst lag hier Molecaten Park Napoleon Hoeve, maar die moest en wilde plaats maken voor dijkverzwaring, nieuwe natuur en een nieuw vakantiepark. Het resultaat is een verbrede duinenrij en het unieke natuur- en recreatiegebied 'Waterdunen'. En dus ook het nieuwe vakantiepark NatuurVakantiepark Waterdunen met bijzondere verblijfsaccommodaties en duincamping. Exclusieve recreatie, inclusief natuur, geldt hier als rendabel verdienmodel.

Als reactie op de starre en strikte regelgeving worden tienduizenden ha met een recreatieve bestemming niet mede ingezet voor een vrijwillige ondersteuning van natuurdoelen op de recreatieterreinen; vanwege de belemmeringen die recreatieondernemers dan tegenkomen als ze hun bedrijf verder willen ontwikkelen. Bovendien is er terughoudendheid om aan te haken bij het idee van tijdelijke natuur, uit angst om zichzelf op slot te zetten (omdat als er eenmaal natuur is er vermoedelijk niets 'economisch' meer mag). De regelgeving zal hierop dus eerst aangepast moeten worden.

De RECRON heeft samen met Staatsbosbeheer, Natuurmonumenten, Geldersch Landschap en Kastelen, Gelderse Natuur- en Milieufederatie, Stichting Landschapsbeheer Gelderland, Veluwefonds en IVN Gelderland het manifest 'Wild van de Veluwe' ondertekend. Het manifest dat nu inmiddels met meerdere stakeholders wordt doorontwikkeld naar een concrete agenda, streeft onder meer naar vitale vakantieparken op de Veluwe die rekening houden met natuur. Of formeel geformuleerd:

"Wij zien enorme mogelijkheden om de toeristisch-recreatieve infrastructuur en de beleving van de Veluwe - in combinatie met natuurontwikkeling - te verbeteren. Maar dan moeten we wel durven kiezen voor de toekomstgerichte ondernemer die als ambassadeur van de Veluwse natuur wil optreden en moeten we ook durven kiezen voor sanering en opruimen van die parken die feitelijk al aan de recreatie onttrokken zijn en het landschap verrommelen."

Feitelijk doen recreatieondernemers al langere tijd aan het nodige voor natuurbehoud en ontwikkeling. Bijvoorbeeld voor het landgoed De Elsgraven van Landal (in Twente) is een bedrijfsnatuurplan opgesteld waarin gekeken wordt naar een betere inpassing van het landgoed in de omgeving/het landschap en de mogelijkheden voor meer biodiversiteit op het landgoed zelf. Het bedrijfsnatuurplan gaat in op de kaders- en richtlijnen vanuit de landelijke, provinciale en gemeentelijke wetgeving. Er is een gebiedsanalyse gemaakt en er heeft een inventarisatie op het landgoed plaatsgevonden om tot verbeterpunten te komen.

Tegelijkertijd valt er echter meer te halen uit de 'natuurinitiatieven' van recreatieondernemers, stelt Gelsing. Bijvoorbeeld door (nauwere) samenwerking van ondernemers met terreinbeherende en groene organisaties over vergroening van recreatieterreinen. De achterliggende gedachte hierbij is dat 'groen' en 'natuur' een essentieel onderdeel zijn van het recreatieproduct. Je zou kunnen stellen dat de helft van de beleving van het vakantieproduct toe te rekenen is aan groen en natuur. Maar dat is niet iets van de laatste jaren. Dat was 20 of 30 jaar geleden natuurlijk ook al het geval. Maar de bewustwording over de rol die natuur speelt ook binnen het recreatiebedrijf is de laatste jaren onder ondernemers wel toegenomen.

\footnotetext{
32 Zie http://www.molecaten.nl/waterdunen)
} 
Feit blijft wel dat de omstandigheden van de locatie de mogelijkheden bepalen. Dat betekent dat ruimte voor maatwerk essentieel is: er is geen generieke manier van hoe natuur en recreatie optimaal gecombineerd kunnen worden. De opgave is om de recreatieondernemer uit te dagen vanuit de gedachte dat natuur een cruciaal onderdeel van het bedrijf is. Laat hiertoe kansen en mogelijkheden zien, maar timmer niet van te voren alles dicht. Wees flexibel, want wat voor de ene ondernemer geldt, hoeft niet voor een ander van toepassing te zijn.

Tot slot nog een opmerking over niche-vorming: recreatieondernemers die exclusief overnachten in de natuur zouden willen faciliteren, mogen dat momenteel niet, maar straks misschien wel. Dat vormt mogelijk een toekomstige niche en is goed voor de beeldvorming en daarmee het draagvlak voor natuur en recreatie.

\section{Visie ten aanzien van de Rijksnatuurvisie}

RECRON kijkt positief aan tegen de Rijksnatuurvisie van het ministerie van EZ. Een term als 'natuurinclusieve economie' past helemaal in de lijn die RECRON voorstaat. RECRON onderschrijft dat natuur midden in de samenleving moet (komen te) staan en prijst de aspiratie en dynamiek die met de Rijksnatuurvisie wordt beoogd. Maar tegelijkertijd stellen ze zich de vraag hoe deze visie, met haar ambities, zich verhoudt tot wetgeving (zoals de Natuurbeschermingswet). Deze wetgeving is vaak star en strikt en lijkt op gespannen voet te staan met de ideeën uit de Rijksnatuurvisie. Kortom, hoe vindt de daadwerkelijke implementatie van de Rijksnatuurvisie plaats? 



\section{$5 \quad$ Een uitwerking van de recreatiesector}

\section{$5.1 \quad$ Introductie ${ }^{33}$}

In het vorige hoofdstuk is de recreatiesector als één van de casussen beschreven. In dit hoofdstuk wordt nader ingegaan op de vraag wat de opschalingsmogelijkheden zijn binnen de recreatiesector om - geheel in lijn met natuurinclusief ondernemen - meer dan voorheen te profiteren van én te investeren in natuur. Voor opschaling is het van belang dat de visie van enkele koplopers voor natuurinclusief ondernemen wordt overgedragen op een grote groep ondernemers, zodat deze visie algemeen geldend wordt.

Het natuurinclusief handelen van ondernemers is grotendeels afhankelijk van de voorkeuren van de consument en diens handelen bij de selectie van een recreatiebestemmingen. Met andere woorden in hoeverre speelt natuur een rol bij de recreatiekeuze van de consument, en wat is hij bereid te betalen voor die natuurfactor. Om te bereiken dat het voor de recreatiesector mainstream wordt om natuurinclusief te ondernemen, moet er een redelijk groot marktpotentieel zijn.

\subsection{Manifeste vraag naar natuur in de recreatiesector}

Om iets over de potentiële vraag te kunnen vertellen, is het van belang om zicht te krijgen op de manifeste vraag. Er zijn gegevens over hoeveel mensen de natuur bezoeken. Bossen en agrarische gebieden blijven de gebieden waar verreweg de meeste personen in Nederland in hun vrije tijd naar toe gaan (Donders \& Goossen, 2012). Het percentage personen dat een bezoek bracht aan bossen bleef in 2012 nagenoeg gelijk aan 2010 met circa 13\% (Figuur 5.1). Het agrarisch gebied werd in 2012 door bijna 14\% van de Nederlanders voor een recreatieactiviteit bezocht en stijgt hiermee met $12 \%$ ten opzichte van 2010. Nog niet eerder overtrof het percentage personen dat een bezoek bracht aan het agrarisch gebied het percentage personen dat een bezoek bracht aan de bossen. Het percentage personen dat een bezoek aan een natuurgebied heeft gemaakt, is ook in 2012 weer gestegen ten opzichte van voorgaande jaren, namelijk tot 5,5\%. Bezoek aan zee bleek in 2012 het minst populair. Dit daalde tot net onder de 3\%. Het percentage personen dat een bezoek bracht aan park, recreatiegebied en rivier-, plas- en meergebieden liet eveneens een daling zien. Parken en recreatiegebieden hadden in 2012 in absolute aantallen echter wel iets meer personen dan in 2010 en hebben dus mede geprofiteerd van de toename van personen in groene gebieden in absolute aantallen. De zee en watergebieden lieten ook in absolute aantallen een daling zien in 2012.

Tevens zijn er vele onderzoeken naar de mechanismen die van belang zijn bij natuurbezoek en het gebruik van ecosystemen. Ecosystemen leveren namelijk een aantal culturele diensten die samenhangen met recreatie; zogenoemde 'recreatiediensten' (Bouwma et al., 2014). Hiermee wordt het geheel van de zintuigelijke ervaring aangeduid (tastzin, gezicht, gehoor, reukzin) die iemand opdoet als hij/zij in de natuur recreëert. Deze ervaring wordt bepaald door de combinatie van de aanwezige natuur en de aanwezige recreatieve voorziening, waarbij de natuur een onderdeel is van de belevingswaarde van het gebied en de recreatieve voorziening een onderdeel van de gebruikswaarde (zie Figuur 5.2). De ervaring kan pas worden opgedaan als men ook daadwerkelijk in het gebied kan zijn door middel van allerlei paden etc. Bij daadwerkelijk recreatief gebruik van een gebied dat in potentie de recreatiedienst kan leveren, wordt de recreatiedienst manifest. De recreatiedienst is dan het eindresultaat van vraag- en aanbod naar recreatie, waarbij interveniërende variabelen een rol spelen.

\footnotetext{
${ }^{33}$ Dit hoofdstuk is gebaseerd op WOt-interne notitie 62 van C.M. Goossen en F. Langers (2013).Bereidheid van de waterrecreatiesector om te investeren in hun omgeving. Wageningen, WOT Natuur en Milieu.
} 


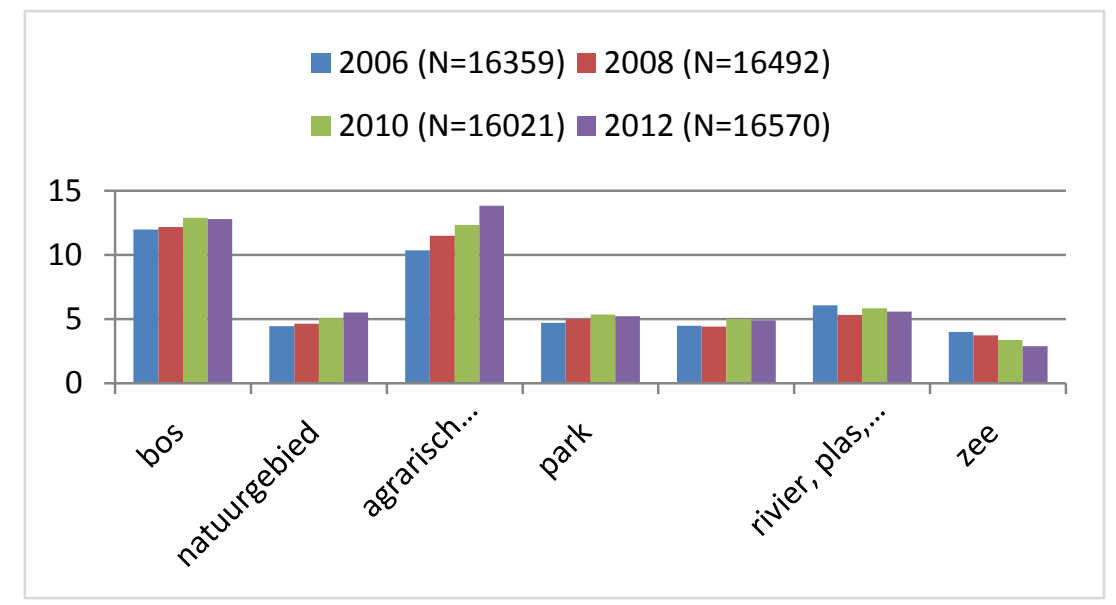

Figuur 5.1: Bezoek (\%) aan groengebieden Bron: CVTO 2012-2013, bewerking Alterra.

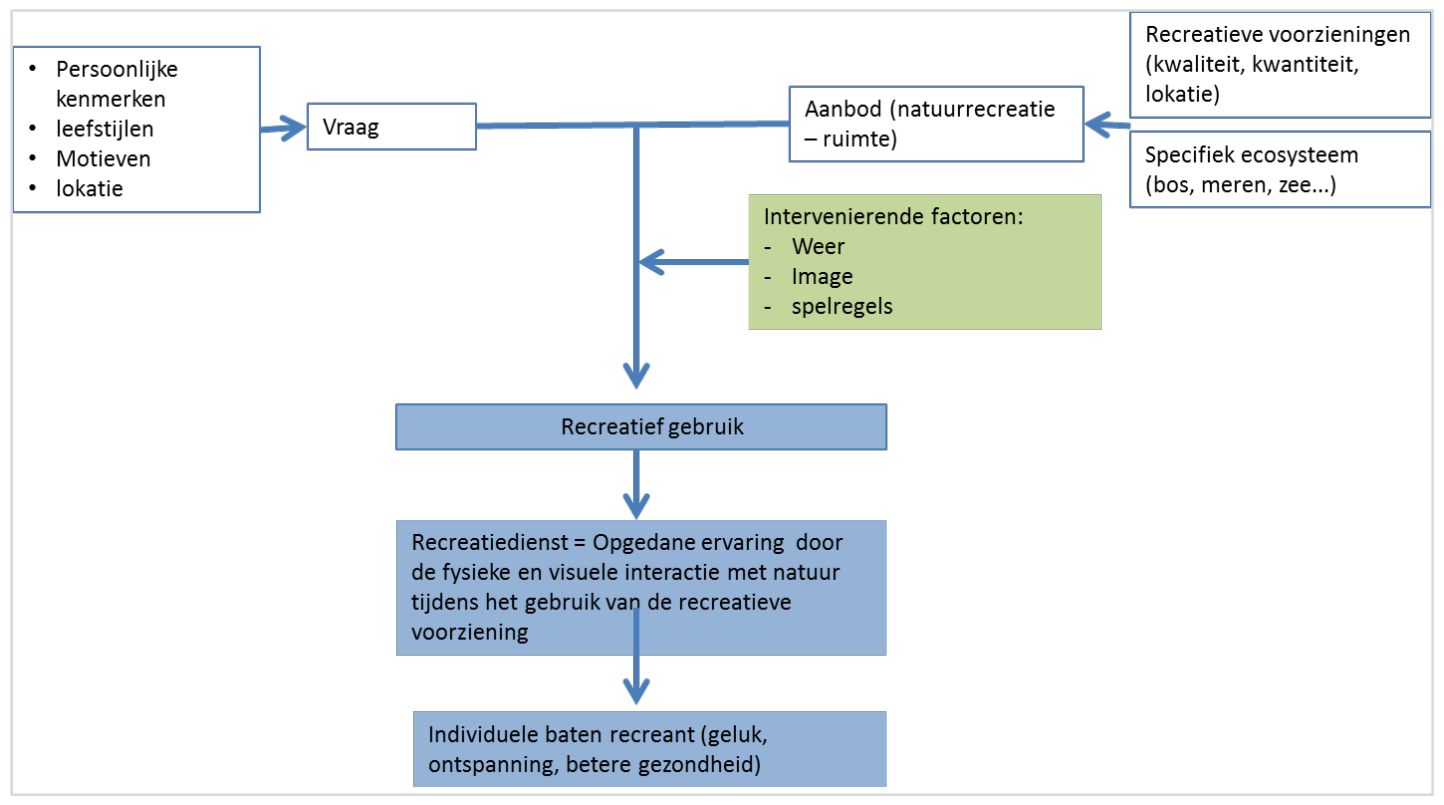

Figuur 5.2: De recreatiedienst is het resultaat als vraag en aanbod bij elkaar komen.

De vraag naar een recreatiedienst heeft relaties met onder andere de persoonlijke kenmerken van recreanten, hun recreatiemotieven en hun leefstijl. Het aanbod aan recreatiemogelijkheden kan worden beschreven in termen van kwantiteit en kwaliteit van de ecosystemen en aanwezige recreatievoorzieningen en de locatie van de voorzieningen.

Er zijn ook interveniërende variabelen die invloed hebben op het recreatief gebruik van een gebied; bij regenachtig weer zal er minder recreatief gebruik zijn. Ook het imago van een gebied of plek heeft effect op het recreatief gebruik evenals spelregels die door overheid, beheerders en eigenaars van recreatieaanbod worden gesteld. De meeste bos- en natuurterreinen zijn bijvoorbeeld 's nachts niet toegankelijk of bepaalde plekken zijn afgesloten voor recreatief gebruik. Er is dan geen gebruik, dus geen profijt en er is op dat moment of op die plek geen sprake van een recreatiedienst van een ecosysteem. De spelregels rondom recreatie betreffen ook de financiering van het beheer van recreatievoorzieningen. In Nederland is de heersende mening dat je voor een bezoek aan natuurgebieden niet hoeft te betalen. De natuur moet voor iedereen toegankelijk zijn. Er zijn in Nederland slechts enkele gebieden waar men wel voor de toegang dient te betalen (o.a. de Hoge Veluwe, de gebieden van de Provinciale Waterleidingmaatschappij Noord-Holland en van de Amsterdamse Waterleiding Duinen).

De recreatiedienst levert vervolgens effecten op die te verdelen zijn in effecten op het niveau van de individuele recreant of op het niveau van de maatschappij als geheel. Op individueel niveau betreft het bijvoorbeeld plezier, ontspanning of een betere gezondheid. Op maatschappelijk niveau zijn er 
maatschappelijke effecten zoals groter draagvlak voor natuur en economische effecten zoals het genereren van omzet bij recreatieondernemers via bestedingen en werkgelegenheid of lagere kosten voor de gezondheidszorg.

Naast dit recreatief gebruik in de natuur waarvoor meestal niet betaald hoeft te worden, kan er ook gekeken worden naar de producten en diensten waarvoor wel betaald moet worden en een relatie hebben met natuur. Daarbij gaat het om overnachten in de natuur, consumptieve bestedingen in de natuur en eigen financiële bijdragen van consumenten aan beheer en ontwikkeling van natuur (compensatie vliegreis etc.).

De groei van deze nichemarkten is ook terug te vinden bij andere sectoren. Zo stijgt het aantal consumenten dat hun vliegreis compenseert elk jaar. Bijna $2 \%$ van alle klanten bij CheapTickets kiest bewust voor het compenseren van de $\mathrm{CO}_{2}$-uitstoot van hun vliegreis via het boeken van een 'groene stoel'. In het eerste kwartaal van 2013 is het aantal 'groene vliegreizigers' dat boekt via de ticketvergelijker met $86 \%$ gestegen ten opzichte van het eerste kwartaal 2012.

Om te onderzoeken of er nog ruimte zit in de totale vraag naar recreëren in de natuur, zal in de volgende paragraaf aandacht worden besteed aan de vraagkant van het model.

\subsection{Marktsegmenten}

De vrije tijd is beperkt en wordt verdeeld over diverse vrije tijdsactiviteiten. Consumenten moeten dus keuzes maken. In 2012 is het cluster buitenrecreatie met 8\% gestegen ten opzichte van 2010. Maar het cluster 'rode' recreatie waarvoor meestal betaald moet worden (waaronder funshoppen, uitgaan, bezoek attracties en evenementen, cultuur en wellness) is in dezelfde periode gestegen met $11 \%$ en het cluster sporten met zelfs $13 \%$. Desalniettemin is wandelen al jaren de belangrijkste vrije tijdsactiviteit met 481 miljoen wandelingen in 2012 (een stijging met bijna 18\% ten opzichte van 2010). Deze mensen gaan voor een deel ook in de natuur wandelen. Welk deel dat doet, hangt van een sterk aantal persoonlijke factoren af, zoals waarden en normen, motieven, preferenties, mogelijkheden, etc. Vandaar dat in de recreatiesector vaak met segmenten wordt gewerkt om de vraag beter te kunnen duiden.

Wie het gedrag van de consument van vandaag wil begrijpen, kan niet meer volstaan met het onderzoeken van demografische aspecten als leeftijd, gezinsfase of inkomen. Een aantal van deze aspecten is nog steeds van belang, maar verklaren steeds minder het feitelijk gedrag van de consument. Het is al lang niet meer zo dat alleen de consumenten die wat meer te besteden hebben, in de luxere restaurants dineren en de consumenten die wat minder te besteden hebben, naar een eenvoudig eetcafé gaan. Consumenten kiezen vooral op basis van wensen, motieven en interesses.

Om enige eenheid in de verscheidenheid van consumenten aan te brengen, worden indelingscriteria geformuleerd om consumenten meer groepsgewijs in beeld te krijgen. In hoofdstuk 2 van dit rapport zijn we hier al uitvoerig op in gegaan. Belangrijke uniformerende dimensies die toen aan bod kwamen en op basis waarvan groepen consumenten van elkaar worden onderscheiden, zijn variatiebehoefte en behoudzucht, of de dimensie eigen- en collectief belang, maar er zijn ook indelingen naar belevingsbehoeften en motieven van recreatiegedrag.

Zo is er in hoofdstuk 2 ingegaan op het WIN-model en werd ook het Mentality ${ }^{\mathrm{TM}}$-model van Motivaction genoemd. Aanvullend op deze twee segmenteringsmodellen is er de indeling naar doelgroepen bij SmartAgent, gebaseerd op leefstijlen van mensen. Daarbij is gebruik gemaakt van het BSRR-model (Brand Strategy Research), een model dat gebaseerd is op sociologie (gericht op individu of groep) en psychologie (introverte of extroverte houding). Bij de BSR $囚$-segmentatie wordt vooral gekeken naar de motieven en drijfveren achter het gedrag van consumenten. Aan de basis van het onderzoek staat een bestand ('CVTO-jaarbestand') met 4.285 respondenten aan wie onder andere gevraagd is welke recreatieactiviteiten zij het afgelopen jaar ondernomen hebben. Daarnaast hebben deze respondenten vragen beantwoord waarmee hun BSR-leefstijlprofiel is bepaald. 
De motiefindeling van Alterra Wageningen UR is gebaseerd op motivatie en de intensiteit van de ervaring; een geleidelijke schaal van een oppervlakkige ervaring, waarin de recreant toeschouwer is, tot een intens beleefde ervaring, waarin de recreant volledig opgaat in de omgeving. Cohen is de grondlegger van het gebruik van doelgroepen op basis van dimensies van beleving (Goossen \& De Boer, 2008). Cohen ziet recreatie als een zoektocht naar het 'andere', en onderscheidt vijf ervaringswerelden. Elands \& Lengkeek (2000) borduren voort op zijn werk. Zij stellen dat de spanning tussen de dagelijkse leefwereld en de leefwereld van recreatie verschillende vormen en intensiteit aan kan nemen. Ook zij werken met vijf verschillende ervaringswerelden: amusement, afleiding, interesse, vervoering en toewijding. De diepte van de ervaringen neemt toe van oppervlakkig (amusement) tot intens (toewijding). Bij amusement is de afstand tot de dagelijkse werkelijkheid het kleinst. Bij afleiding wordt de afstand al wat groter. Het gaat er om even weg te zijn van het normale, dagelijkse leven; even ontspannen en de batterij opladen. Bij interesse neemt de afstand tot de dagelijkse werkelijkheid nog verder toe. Het gaat om kennismaken met de geschiedenis van een bepaald gebied, met andere volken; het stimuleren van de verbeelding. Als de ervaringen nog dieper gaan, kan zelfs de fase van vervoering optreden; daarbij speelt ook confrontatie met jezelf en je (fysieke) grenzen en daarmee het verwerven van zelfkennis een rol. In de fase van toewijding ten slotte, gaat het erom volledig geabsorbeerd te worden door een andere wereld, in een zoektocht naar authenticiteit (Elands \& Lengkeek, 2000).

Deze indeling heeft gediend als inspiratiebron voor de vijf recreatiemotieven (Gezelligheid, Even tussen uit, Interesse, Opgaan in andere wereld en Uitdaging) die Goossen \& De Boer (2008) hanteren. Hun motieven zijn in de eerste plaats op recreanten gericht, terwijl de oorspronkelijke indeling van Elands \& Lengkeek zich sterk op toeristen richtte. De vijfde ervaringswereld, toewijding, maakt dit duidelijk. Bij toewijding wil men deel uit gaan maken van 'die andere wereld', bijvoorbeeld door zich (tijdelijk) te vestigen in een ander land. Toewijding is dus minder goed van toepassing op recreatie. Daarnaast bleek bij de validatie van de ervaringswerelden (Bauman, 2002) dat uitdaging een belangrijk motief is bij recreatie. Dit uit zich in sportieve recreatieactiviteiten, waarbij de strijd met jezelf en de natuurlijke elementen centraal staan. Toewijding is daarom vervangen door Uitdaging.

Uit diverse onderzoeken blijkt dat het motief sterk gerelateerd is aan het type recreatieactiviteit dat in de natuur uitgevoerd kan worden, maar dat Gezelligheid meestal het belangrijkste motief is, gevolgd door het motief Even tussen uit (Tabel 5.1).

Tabel 5.1

Verdeling (\%) naar motieven op basis van CVTO 2008 en 2012.

\begin{tabular}{|c|c|c|c|c|c|c|c|c|c|c|}
\hline & \multicolumn{2}{|c|}{$\begin{array}{l}\text { Gezellig- } \\
\text { heid }\end{array}$} & \multicolumn{2}{|c|}{$\begin{array}{c}\text { Even tussen } \\
\text { uit }\end{array}$} & \multicolumn{2}{|c|}{ Interesse } & \multicolumn{2}{|c|}{$\begin{array}{l}\text { Opgaan in } \\
\text { natuur }\end{array}$} & \multicolumn{2}{|c|}{ Uitdaging } \\
\hline & 2008 & 2012 & 2008 & 2012 & 2008 & 2012 & 2008 & 2012 & 2008 & 2012 \\
\hline Wandelen & 44.6 & 39.7 & 26.6 & 27.7 & 6.9 & 9.5 & 7.7 & 9.1 & 14.1 & 14.1 \\
\hline Fietsen & 45.2 & 38.1 & 21.7 & 25.1 & 6.9 & 10.4 & 6.0 & 8.9 & 20.2 & 17.5 \\
\hline Recreëren aan water & 52.7 & 54.9 & 24.8 & 25.8 & 6.3 & 5.6 & 5.6 & 4.5 & 10.6 & 9.2 \\
\hline $\begin{array}{l}\text { Recreëren in park, bos } \\
\text { e.d. }\end{array}$ & 52.4 & 50.4 & 23.2 & 25.0 & 7.4 & 8.0 & 8.1 & 7.5 & 8.9 & 9.1 \\
\hline Toertochtjes met de auto & 62.8 & 58.5 & 20.3 & 21.7 & 8.9 & 10.3 & 4.7 & 5.0 & 3.3 & 4.5 \\
\hline Toertochtjes met de motor & 42.7 & 33.7 & 37.4 & 46.5 & 5.3 & 4.8 & 2.0 & 2.8 & 12.7 & 12.2 \\
\hline $\begin{array}{l}\text { Varen met motorboot } \backslash \\
\text { jacht }\end{array}$ & 58.4 & 61.9 & 22.1 & 21.2 & 6.8 & 6.2 & 5.4 & 4.6 & 7.3 & 6.2 \\
\hline Vissen & 30.1 & 30.2 & 33.8 & 31.5 & 5.8 & 7.7 & 13.5 & 14.4 & 16.9 & 16.2 \\
\hline $\begin{array}{l}\text { Joggen \ hardlopen } \backslash \\
\text { trimmen }\end{array}$ & 9.2 & 10.2 & 16.3 & 18.9 & 1.9 & 2.8 & 2.2 & 2.5 & 70.4 & 65.7 \\
\hline Mountainbiken & 9.5 & 9.2 & 16.0 & 20.2 & 2.4 & 2.1 & 3.8 & 2.4 & 68.2 & 66.2 \\
\hline Skaten/skeeleren & 21.7 & 26.3 & 13.4 & 12.4 & 4.3 & 4.7 & 3.3 & 2.6 & 57.3 & 54.1 \\
\hline Wandelsport & 35.5 & 31.5 & 23.5 & 22.7 & 6.5 & 7.1 & 7.4 & 8.7 & 27.1 & 30.0 \\
\hline Wielrennen & 10.4 & 11.5 & 17.4 & 16.8 & 1.7 & 2.2 & 0.8 & 2.5 & 69.7 & 67.0 \\
\hline Totaal & 36.6 & 35.1 & 22.8 & 24.3 & 5.5 & 6.3 & 5.4 & 5.8 & 29.7 & 28.6 \\
\hline
\end{tabular}


Bij het recreatiemotief hoort een wens, die persoonsgebonden is maar wel van dag tot dag kan verschillen: vandaag heb ik zin om te ontspannen in een stille rustige omgeving, morgen is het mijn wens om bij te komen middenin de gezellige drukte. Vanuit deze wens volgt een specificatie van de voorkeur voor een type omgeving: bijvoorbeeld een rustig plekje langs de rivier, of een terrasje in het stadspark. Waar je tenslotte heengaat - het feitelijke gedrag - hangt af van de mogelijkheden die er zijn: hoeveel tijd heb je en waar kun je dan komen, welke plekken ken je, wat wil je doen, hoeveel wil je uitgeven (Donders et al., 2011). Goossen et al. (2010) stellen vast dat het meestal ook niet bij één motief blijft bij een uitstapje. Mensen combineren bijvoorbeeld vaak 'Gezelligheid' en 'Even tussen uit' als zij gaan recreëren, zo bleek uit hun onderzoek naar combinaties van motieven. Het is meer een glijdende schaal, waarbij er meestal wel sprake is van één hoofdmotief. Daarbij blijken er ook verschillen te bestaan tussen de motieven en gebruikswaarden en belevingswaarden. Zo willen recreanten met het motief gezelligheid graag voorzieningen in de natuur terwijl recreanten met het motief Opgaan in de natuur juist helemaal geen voorzieningen prefereren. Op basis van divers onderzoeken met de recreatiemotieven komt er wel een beeld naar voren met betrekking tot activiteiten en preferenties. De motieven Gezelligheid en Opgaan in de natuur lijken elkaars tegenpolen.

Bij het natuurinclusief handelen van consumenten speelt ook wat natuur precies inhoud. Wat verstaat men onder natuur. Er zijn verschillende natuurbeelden te onderscheiden.

\section{$5.4 \quad$ Natuurbeelden}

De waardering van natuur kan deels afhangen van de opvattingen over wat natuur is. Sommige Nederlanders willen het liefst een autonome natuur, onafhankelijk van de mens. Ook spontaniteit van de natuur is een belangrijk kenmerk van waardevolle natuur. Anderen benadrukken juist de verwevenheid van de mens met de natuur. De natuur staat voor hen niet los van de mens, en sommigen vinden dat de natuur vooral ten dienste moet staat van de mens. Uit eerder onderzoek (Buijs, 2009) is gebleken dat er vier natuurbeelden zijn, namelijk:

- arcadisch natuurbeeld;

- functioneel natuurbeeld;

- wildernis natuurbeeld;

- breed natuurbeeld.

In het arcadisch natuurbeeld is de natuur vooral een décor voor de recreant. De schoonheid van de natuur en het idyllische plattelandsleven staan centraal. De natuur is toegankelijk voor de recreant. Hier leeft de opvatting dat de mens soms wel en soms niet tot de natuur behoort.

In het functionele natuurbeeld heeft de natuur vooral een functie voor de mens. De natuur moet onderhouden worden zodat zij niet verwildert. Men heeft een voorkeur voor verzorgde natuur.

In het wildernis natuurbeeld is de natuur onafhankelijk als een soort 'oernatuur'. In dit beeld hoort de mens niet tot de natuur. Men heeft een voorkeur voor grote eenheden, vooral ruige natuur. De natuur moet zoveel mogelijk haar gang kunnen gaan en sporen van menselijke invloed worden als storend ervaren.

In het brede natuurbeeld is natuur alles wat groeit en bloeit. De mens behoort zelf ook tot de natuur en er is een voorkeur voor verzorgde natuur. Menselijk ingrijpen wordt niet afgewezen.

Het Planbureau voor de Leefomgeving heeft de opvattingen over natuurbeelden gebruikt en vertaald in toekomstbeelden voor natuur ('kijkrichtingen'). De kijkrichtingen - vier in totaal - zijn ideaaltypische toekomstbeelden, bedoeld om het denken over natuur en landschap op te rekken. Ze zijn daarmee eenzijdig en geen van de kijkrichtingen zal zelfstandig werkelijkheid worden. In de praktijk zullen vaak combinaties voorkomen. De vier kijkrichtingen zijn: vitale, beleefbare, functionele en inpasbare natuur. 
Hieronder worden ze kort samengevat en, om het zo concreet mogelijk te makken, uitgewerkt voor een fictief beekdal. ${ }^{34}$

- Vitale natuur. Het accent ligt op het creëren van grote eenheden natuur, die nodig zijn om ruimte te geven aan natuurlijke processen, zoals het meanderen van de beek en het regelmatig optreden van overstromingen. Buiten de natuurgebieden krijgen de landbouw en andere gebruiksfuncties ruimte om zich te ontwikkelen. Recreatie is in deze kijkrichting wel mogelijk, maar die komt duidelijk op de tweede plaats. Het is dan ook zeer de vraag of de recreatiesector als private partij in dit type natuur zal investeren, omdat de recreatie op de tweede plaats komt te staan. De verwachting is dat dit een nichemarkt is.

- Beleefbare natuur. Het zwaartepunt ligt op het vergroten van de aantrekkelijkheid en toegankelijkheid van het landschap voor natuur en recreatie. Het landschap is kleinschalig met hier en daar recreatiebossen en rustplekken langs de beek. Ook tussen de bebouwing is groen aanwezig. Het buitengebied is goed toegankelijk via fiets- en wandelpaden. Regionale overheden realiseren in samenwerking met andere partijen grote natuurgebieden waar meerdere functies, waaronder recreatie, een plek vinden. Het publiek is betrokken bij het ontwerp en beheer van recreatiegebieden. Het laatste helpt om de hoge kosten van onderhoud te drukken, zeker rond de stad. De natuursector sluit coalities met de recreatiesector en zorgverzekeraars. De landbouw maakt het landelijk gebied toegankelijker en aantrekkelijker, onder meer met hulp van gelden uit het Europese Gemeenschappelijk Landbouwbeleid. De beoogde mainstreaming zal vooral in deze kijkrichting moeten plaatsvinden.

- Functionele natuur. De diensten van de natuur worden duurzaam benut. Waterbekkens langs de beek voorkomen wateroverlast, rietlanden zuiveren water en leveren biomassa op voor energieproductie. Houtsingels en andere landschapselementen bieden plek aan soorten die plagen bestrijden op aangrenzende landbouwgronden en zorgen voor bestuiving. In het beekdal is de veenvorming weer op gang gekomen, waardoor $\mathrm{CO}_{2}$ wordt vastgelegd. In deze kijkrichting zijn productieve en regulerende ecosysteemdiensten met concrete economische en maatschappelijke waarde belangrijk. Vaak wordt niet voor deze diensten betaald, maar verlies ervan zou toekomstige generaties met hoge kosten opzadelen. Dit betekent dat de kans van mainstreaming niet groot is omdat er voor de recreatiesector geen product of dienst is waarvoor betaald moet worden.

- Inpasbare natuur. Particuliere investeerders bouwen woningen in het groen en aan het water. Groen wordt ook aangeplant om de waarde van bestaand onroerend goed te verhogen. De landbouw heeft een grootschalig karakter. Er wordt niet geïnvesteerd in natuurontwikkeling; de beek blijft gekanaliseerd. Deze kijkrichting gaat ervan uit dat natuur belangrijk is, maar mens en economie zijn belangrijker. De overheid beperkt de regelgeving zodat de economische mogelijkheden van natuur meer kunnen worden benut. Dit betekent tegelijk dat gebruiksfuncties regelmatig met elkaar in conflict komen. Met regulering kunnen meer activiteiten een plek krijgen. De inpasbare natuur heeft mogelijkheden om te mainstreamen bij de recreatiesector.

Bij al deze kijkrichtingen zijn er mogelijkheden om recreanten te trekken door gebieden zodanig in te richten en te beheren dat er aantrekkelijke belevingswaarden ontstaan voor specifieke vraagsegmenten, uiteraard in combinatie met het natuurdoel.

Op basis van deze natuurbeelden is het niet verwonderlijk dat het draagvlak voor natuur groot is in Nederland. De definitie van draagvlak gehanteerd door De Boer et al. (2014) luidt: "Het maatschappelijk draagvlak voor natuur en landschap en het daarmee verbonden natuur- en landschapsbeleid is het geheel van gevoelens, meningen, houdingen, visies en ondersteunende handelingen en acties van burgers ten aanzien van onderhoud, bescherming of ontwikkeling van natuur en landschap en het daarmee verbonden overheidsbeleid". Uit de longitudinale studie (De Boer et al., 2014) blijkt dat een grote groep burgers natuurbescherming belangrijk vindt, regelmatig de natuur bezoekt en activiteiten verricht voor natuur en landschap. Slechts een beperkte groep is actief betrokken bij burgerinitiatieven voor natuur in de woonomgeving. In vergelijking met de resultaten uit 2006 is het draagvlak voor beleidsmaatregelen iets afgenomen. Verder zijn mensen positiever geworden over de hoeveelheid natuur in Nederland en bezoekt men vaker de natuur. De studie laat ook zien dat het aandeel actieve burgers echter bij lange na niet voldoende is om een verder terugtredende overheid op te vangen.

34 Gebaseerd op R. van Oostenbrugge (2011). 


\subsection{Ontwikkelingen en Trends}

Tot nu toe is vooral naar de huidige manifeste vraag gekeken. Er is een aantal maatschappelijke ontwikkelingen en trends gaande die wellicht informatie kunnen opleveren over een mogelijke latente vraag om zo de 'vraag naar recreatieve diensten' in kaart te kunnen brengen. Zonder uitvoerig op alle mogelijke ontwikkelingen en trends in te gaan, worden er wel een aantal besproken waarvan gedacht wordt dat die van belang zouden kunnen zijn.

\section{Demografie}

Demografische ontwikkelingen laten een vergrijzing zien. De huidige en toekomstige oudere is welvarender, fitter en mobieler dan de oudere van voorheen, en daardoor zeer actief en uithuizig in de vrije tijd (Goossen et al., 2013). De vergrijzing heeft daarmee gevolgen voor de mobiliteit, het milieu, het ruimtegebruik en de lokale en regionale economie. Men trekt er in groten getale op uit; met de fiets, de auto en het vliegtuig; naar stad en platteland; in binnen- en buitenland. Het aantal uitstapjes en dagtochten neemt toe, evenals het aantal korte en lange vakanties. Wandelen, fietsen en golfen zijn populaire activiteiten onder ouderen, waardoor het gebruik van natuur en agrarische gebieden zal toenemen. Deze veranderingen worden enigszins gedempt door de verhoogde arbeidsparticipatie van 55-plussers en de toekomstige verhoging van de pensioengerechtigde leeftijd. Meer tijd besteed aan werk betekent immers minder vrije tijd.

We blijven dus langer leven in Nederland, waardoor de gemiddelde leeftijd stijgt. Dit zou kunnen betekenen dat de motieven Gezelligheid en Uitdaging in omvang afnemen. Juist deze motieven zijn namelijk populairder bij jongere mensen. Met name het motief Gezelligheid wordt gekozen door jonge gezinnen, waarbij met de kinderen activiteiten worden ondernomen. Wanneer kinderen de deur uit zijn, dan worden andere motieven belangrijker. Interesse en volledig Opgaan lijken dan in omvang toe te nemen omdat deze motieven meer door ouderen worden gekozen (Tabel 5.2).

\section{Opleidingsniveau}

Een andere verwachting is dat de huishoudgrootte daalt; er komen meer alleenstaanden en tweepersoonshuishoudens mede als gevolg van de leeftijdsstijging. Dit alles heeft tot gevolg dat het belang van het motief Gezelligheid zal afnemen. Daarentegen stijgt het belang van de motieven Tussen uit en volledig Opgaan, aangezien die meer door een- en tweepersoonshuishoudens worden gekozen.

Een andere ontwikkeling is dat de gemiddelde opleiding van Nederlanders zal stijgen. Dit zou kunnen betekenen dat wederom de omvang van het motief Gezelligheid afneemt, omdat dit motief vaak wordt gekozen door mensen met een lagere opleiding. Hetzelfde geldt voor het motief volledig Opgaan. Daarentegen zouden de motieven Tussen uit en Interesse belangrijker worden, omdat deze motieven meer worden gekozen door mensen met een hogere opleiding.

Tabel 5.2

Verwachte ontwikkeling in de omvang per recreatiemotief per kenmerk.

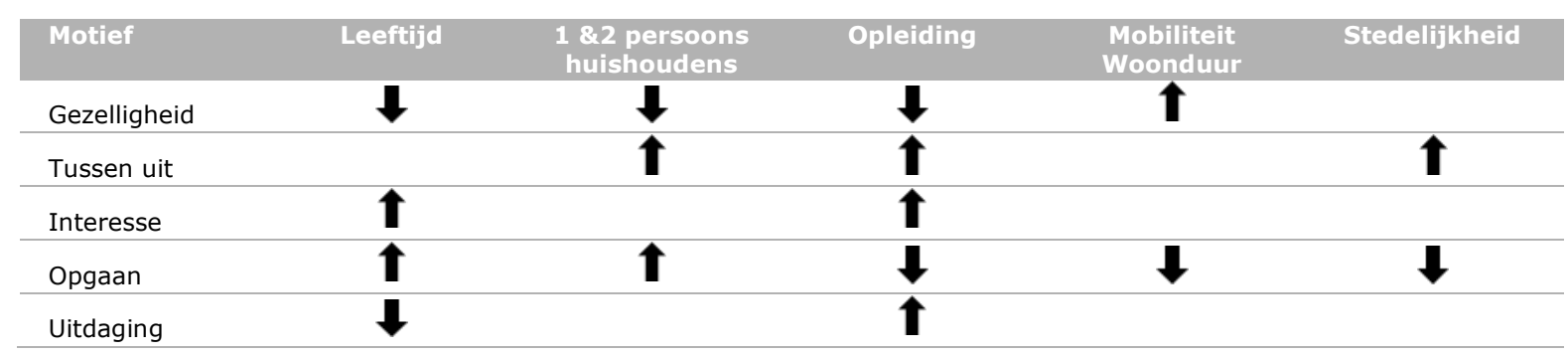

Het is moeilijk om de omvang van de motieven voor de toekomst te voorspellen. Maar gezien de relaties kan samenvattend worden gesteld dat de motieven Gezelligheid en Tussen uit in omvang de belangrijkste motieven blijven. Wel zal het belang van het motief Gezelligheid iets afnemen ten gunste van het motief Tussen uit. Ook het motief Uitdaging zal iets aan belang inleveren ten gunste van het motief Interesse. Het motief volledig Opgaan zal weinig in omvang veranderen. Wel moet worden opgemerkt dat voorspellingen altijd een mate van onzekerheid hebben. 


\section{Duurzaamheid}

Een andere trend is de toenemende invloed van duurzaamheid. Er is een ontwikkeling gaande waarbij de consument steeds meer rekening houdt met de consequenties van zijn handelen. Ook bedrijven spelen in op deze trend en het is nu heel normaal dat er een veelheid aan biologische producten in de supermarkten ligt of in ieder geval voorzien van een keurmerk. Ook in het toerisme zijn er steeds meer bedrijven (vooral de grotere spelers) die inspelen op de trend van duurzaamheid om maatschappelijk verantwoord te ondernemen. Het aantal recreatiebedrijven met een Greenkey keurmerk is gestegen van 360 in 2011 naar 600 in 2015. Dit heeft overigens meer te maken met milieu en ethische overwegingen dan met natuur. Indien er wel een relatie is met natuur dan ligt de ambitie van bedrijven veelal op het realiseren van beleefbare en functionele natuur (Breman et al., 2014).

\subsection{Latente vraag recreatiediensten}

Om bedrijven te laten investeren in natuur helpt het als er een markt is van consumenten die willen betalen voor een dienst of een product. De beslissing om een product of dienst aan te schaffen is een ingewikkeld proces, waarbij houding, emoties en wensen een rol spelen. Het aanvaarden van een nieuw product of dienst kan worden beschreven aan de hand van de diffusietheorie van Everett Rogers, waarover uitvoerig in hoofdstuk 2 is gerapporteerd. Daarin werden onder meer de segmenten 'Innovators' en 'Early Adopters' geïntroduceerd. Passen we deze twee segmenten specifiek toe op de relatie natuur en recreatie, dan kunnen we stellen dat deskundigen (ecologen, beheerders en beleidsmakers) Innovators en Early Adopters zijn, die graag zien dat burgers zich verbonden voelen met natuur en met de wijze waarop ze omgaan met de natuur in Nederland.

Tot voor kort waren deze beleidsmakers en professionele, gevestigde natuurorganisaties dominant in het vormgeven van natuurbeheer in Nederland. Er vond een uitwisseling plaats van voornamelijk technisch-ecologische inzichten, waarbij via de Ecologische Hoofdstructuur (EHS) natuur en landbouw sterk gescheiden werden. De kloof met burgers was groot: juist doordat het natuurbeheer werd bediscussieerd in wetenschappelijke en zakelijke termen, werden andere actoren bewust of onbewust uitgesloten van het debat. De nieuwe actoren die via onder meer internetforums in beeld komen, benadrukken andere kanten van het beheer dan experts, met meer aandacht voor beleving en voor emoties die maatregelen in het natuurbeheer oproepen. Zij eisen zeggenschap over hun leefomgeving, zowel ter ondersteuning als ter bestrijding van beoogde maatregelen.

Professionals gaan er vaak van uit dat wanneer er maar meer kennis in de burger wordt gestopt om op deze wijze de meerwaarde te laten zien, men tot overeenstemming zal komen. Dit komt wellicht omdat de professional (mogelijk al als kind) een basishouding heeft met beleving/emotie en passie voor de natuur (zie Figuur 5.3). Daar heeft hij steeds meer kennis aan toegevoegd om die fascinatie met natuur te kunnen begrijpen en te kunnen ontwikkelen. Maar om kennis tot je te kunnen nemen, zijn vaardigheden voor nodig die niet iedereen heeft of evenveel bezit. Het overbruggen van de kloof kennis-emotie tussen professionals en burgers is daarom een belangrijke stap. Uit onderzoek blijkt (Goossen, 2013; Goossen \& Langers, 2013; Goossen et al., 2013; Breman et al., 2014) blijkt dat passie voor de natuur als vorm van emotie vaak een belangrijke drijfveer is voor ondernemers om te innoveren met natuur-inclusieve diensten.

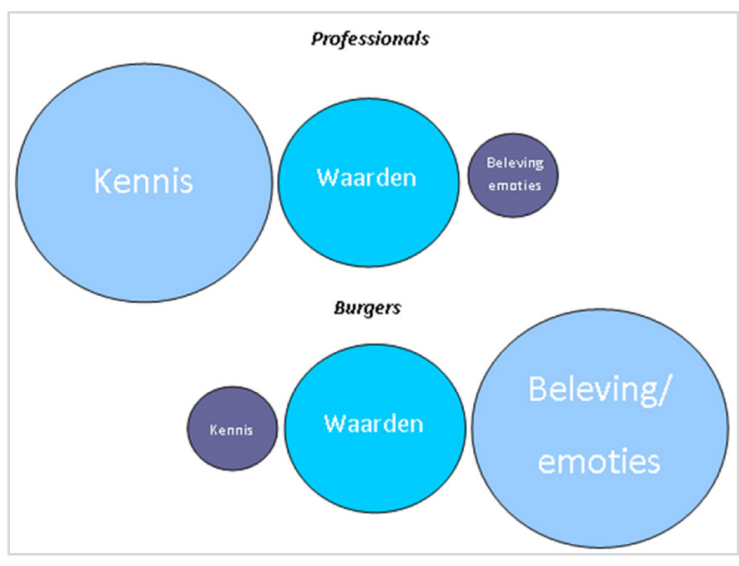

Figuur 5.3: De verhouding tussen kennis, waarden en emoties in de taal van burgers en professionals (Buijs, 2009). 
De kloof zal waarschijnlijk eerder worden gedicht als de professional weer zijn oorspronkelijk aanwezige emotie oproept als basis voor zijn handelen en communicatie met de burger in plaats van kennis.

Bij een latente vraag wordt er wel vanuit gegaan dat er een basishouding aanwezig is die alleen nog niet ingevuld is, ofwel nog niet in gedrag is omgezet. Uit de literatuur blijkt dat gedrag niet automatisch volgt op een basishouding, alhoewel een positieve houding wel noodzakelijk is. Voor de mainstream is het gedrag echter wel het belangrijkste. Een houding levert geen geld op; en gedrag wel. Heberlein (2012) komt tot de conclusie dat een basishouding niet of nauwelijks te veranderen is en dat daarmee ook gedrag niet of nauwelijks duurzaam kan veranderen wanneer niet de juiste elementen worden aangesproken. In de overgang van basishouding naar gedrag zit de latente vraag die dus 'op maat bewerkt' moet worden om tot een (gewenst) gedrag te leiden. Elementen die van invloed zijn op gedragsverandering (Heberlein, 2012) zijn:

- De persoon die gevraagd wordt gedrag te veranderen, moet er een blijvend voordeel bij hebben; dit heeft overeenkomsten met de meerwaarde die de early majority nastreven;

- De persoon die gevraagd wordt gedrag te veranderen krijgt een andere 'rol' te spelen; bijvoorbeeld van consument van natuur naar actievoerder om bomen in straat te behouden;

- Directe waarneming over ander gedrag kan helpen;

- Gedragsverandering heeft een lange looptijd (zie het voorbeeld van niet roken);

- Informatie en kennis zijn belangrijk;

- Creëer een norm op een positieve manier.

Ook hieruit blijkt dat het aanleveren van alleen kennis niet voldoende is om gedrag te veranderen.

\subsection{Omvang donkergroen en lichtgroene natuur}

De commissie rond Prof. mr. Pieter van Vollenhoven ${ }^{35}$ stelt dat natuur op te vatten is als het samenstel van 'donkergroene' en 'lichtgroene' waarden. De commissie ziet natuur en landschap van nationaal belang als de donkergroene natuur zoals de Natura 2000-gebieden. De bescherming in deze gebieden is vooral gericht op de bescherming van specifieke dieren en planten (soorten) en hun leefmilieus (habitats), die gewaardeerd worden om hun zeldzaamheid, internationale belangrijkheid of aaibaarheid [PBL, 2010]. De voorheen genoemde EHS (nu Natuurnetwerk Nederland) dient om de versnippering van die donkergroene natuur tegen te gaan en robuuster te maken. Dit is nodig om de specifieke doelen voor de bescherming van planten en dieren in die gebieden te kunnen bereiken. Daarnaast bestaat nu meer aandacht voor 'lichtgroene natuur' of 'gebruiksnatuur', waar functiekoppelingen tussen natuur, economie, landbouw en recreatie mogelijk zijn. De belevingswaarde van natuur krijgt steeds meer aandacht in het beleid. Zoals eerder is gesteld gaan mensen meestal met meer motieven op pad in de natuur en is die (recreatieve) belevingswaarde ook een continuüm van donkergroene beleving naar lichtgroene beleving. Dat blijkt uit de recreatiemotieven. Wanneer we naar de omvang kijken op basis van een representatieve steekproef onder Nederlanders, dan blijkt dat het motief Gezelligheid het belangrijkst is. Het motief Opgaan in de natuur die de meest overeenkomsten heeft met donkergroene natuur is in omvang veel beperkter.

Het continuüm van donkergroene beleving naar lichtgroene beleving is dan ook van toepassing op de motieven. Wanneer naar de (significante) relaties wordt gekeken uit de diverse onderzoeken ${ }^{36}$, dan blijkt dat er ook een continuüm in zit. Uit de meeste onderzoeken blijken de motieven Gezelligheid en Opgaan in de natuur elkaars tegenpolen. Daarbij kan Opgaan in de natuur opgevat worden als donkergroene natuur. Deze recreanten komen meer in de natuur, vinden het belangrijker dat een bos- of

\footnotetext{
${ }^{35}$ Op verzoek van de toenmalige Staatssecretaris van Economische Zaken, mevrouw Sharon Dijksma, heeft Prof. mr. Pieter van Vollenhoven deze onderzoeksopdracht op persoonlijke titel ter hand genomen. Hiertoe heeft hij een commissie gevormd met de volgende personen: prof. dr. Joop Schaminée, prof. dr. André van der Zande en drs. Bart Swanenvleugel (secretaris). De commissie wordt bijgestaan door drs. Pieter Baars (Nationaal Groenfonds) en mr. Pieter Siebinga (Nationaal Restauratiefonds).

${ }^{36}$ C.M. Goossen en F. Langers (2013).Bereidheid van de waterrecreatiesector om te investeren in hun omgeving. Wageningen, WOT Natuur en Milieu. WOt-interne notitie 62.
} 
natuurgebied er ruig en robuust uit ziet, dat er beschermde diersoorten in voorkomen, zijn ze er meer mee oneens dat als grote hoeveelheden ganzen de oogst op akkers vernielen, ze afgeschoten mogen worden en zijn ze vaker lid van Natuurmonumenten dan recreanten met andere motieven. Recreanten met het motief Gezelligheid hebben meer overeenkomsten met de lichtgroene natuur.

Dit blijkt ook uit het type gebied waar recreanten met een bepaald motief naar toe gaan. De zee wordt meer bezocht door recreanten die meer met het motief Gezelligheid erop uit gaan. Stadsparken zijn meer in trek bij recreanten met het motief Even tussen uit. Natte natuurgebieden die overeenkomsten hebben met donkergroene natuur worden meer bezocht door recreanten met de motieven Interesse en Opgaan in de natuur. Recreanten met het motief Uitdaging zijn meer in bossen te vinden.

Wanneer de ontwikkelingen in omvang en de grootte van de motieven in ogenschouw worden genomen, dan ontstaat een beeld zoals in tabel 5.3 is weergegeven.

Uit tabel 5.3 blijkt dat duingebieden een licht positieve relatie hebben met het motief Gezelligheid. Dat wil zeggen hoe meer men met het motief Gezelligheid gaat recreëren, hoe meer men een duingebied bezoekt. Heide- en zandgebieden hebben daarentegen een negatieve relatie met dit motief. Het belang van dit motief neemt naar verwachting wel iets af, maar blijft van een grote omvang. Investeringen van bedrijven die in een duinlandschap liggen of investeringen om een duin-landschap te maken (zoals project Waterdunen in Zeeland) kan dus positief werken bij bedrijven die zich richten op recreanten en/of toeristen die meer met het motief Gezelligheid gaan recreëren. De concurrentie om recreanten en/of toeristen met dit motief is groot vanwege de omvang en dan heb je als bedrijf voordeel als je in een duinlandschap ligt of een duinlandschap maakt.

\section{Tabel 5.3}

Samenvatting relaties tussen recreatiemotieven en type omgeving.

\begin{tabular}{|c|c|c|c|c|}
\hline Omgeving & Gezelligheid & Tussen uit & Opgaan & Uitdaging \\
\hline \multicolumn{5}{|l|}{ Op of aan zee } \\
\hline \multicolumn{5}{|c|}{ Water/rivier/plas/meer } \\
\hline \multicolumn{5}{|l|}{ Agrarisch } \\
\hline \multicolumn{5}{|l|}{ Recreatiegebied } \\
\hline \multicolumn{5}{|l|}{ Natte natuurgebied } \\
\hline \multicolumn{5}{|l|}{ Duingebied } \\
\hline \multicolumn{5}{|l|}{ Bosgebied } \\
\hline \multicolumn{5}{|c|}{ Heide-stuifzandgebied } \\
\hline \multicolumn{5}{|l|}{ Stadspark } \\
\hline $\begin{array}{l}\text { Omvang } \\
\text { groot } \\
\text { Neemt toe }\end{array}$ & $\begin{array}{l}\text { Omvang groot } \\
\text { Neemt af }\end{array}$ & $\begin{array}{l}\text { Omvang } \\
\text { klein } \\
\text { Neemt toe }\end{array}$ & $\begin{array}{l}\text { Omvang } \\
\text { klein } \\
\text { Neemt af }\end{array}$ & $\begin{array}{l}\text { Omvang } \\
\text { klein } \\
\text { Blijft gelijk }\end{array}$ \\
\hline Positief & Licht positief & neutraal & $\begin{array}{l}\text { Licht } \\
\text { negatief }\end{array}$ & Negatief \\
\hline
\end{tabular}


Droge natuurgebieden hebben een wisselend effect op het motief Tussen uit. Duingebieden hebben een negatieve relatie met dit motief en heide- en zandgebieden een positieve relatie. Aangezien dit motief al belangrijk is in omvang en ook nog aan belang toeneemt, hebben bedrijven die in heide- en zandgebieden liggen een voordeel bij investeringen. Verwacht wordt dat recreanten en/of toeristen die meer met het motief Tussen uit gaan recreëren, dit type landschap vaker bezoeken.

Het andere motief dat in belang toeneemt is Interesse. Dit motief heeft echter een negatieve relatie met droge natuurgebieden (lees: duin- en heide-stuifzandgebieden). Voor bedrijven die in deze gebieden liggen en zich willen richten op recreanten en toeristen met dit motief, is nog onduidelijk waarin het beste kan worden geïnvesteerd. Wellicht kan geïnvesteerd worden in verhalen en wetenswaardigheden over deze gebieden. Investeringen in deze gebieden werken positief voor recreanten die met het motief volledig Opgaan gaan recreëren. Aangezien de omvang van dit motief naar verwachting gelijk blijft, loont het de moeite om in deze gebieden te investeren. Hetzelfde geldt voor recreanten met het motief Uitdaging. In de concurrentie om aandacht van de recreanten met dit motief (dat aan belang afneemt) kan het een voordeel opleveren voor bedrijven die in deze type landschappen liggen.

Veel recreanten gaan met de motieven Gezelligheid en Tussen uit op stap. Bedrijven die in natte natuurgebieden liggen, moeten met iets bijzonders komen indien ze zich richten of willen richten op deze recreanten en/of toeristen omdat er een licht negatieve relatie bestaat tussen dit type landschap en de motieven. Te meer omdat de omvang van het motief Gezelligheid iets afneemt. De omvang van het motief Tussen uit neemt juist toe.

Het motief Interesse heeft een positieve relatie met natte natuurgebieden. Aangezien het belang van dit motief toeneemt, zouden investeringen van bedrijven die in of nabij dit type landschap liggen, een voordeel kunnen opleveren. Wel moet worden opgemerkt dat de absolute omvang van dit motief niet groot is. Hetzelfde geldt voor het motief volledig Opgaan. Recreanten met dit motief gebruiken dit type landschap meer en investeren kan dus positief werken. Ook al blijft de omvang van dit motief gelijk. Ook uit ander onderzoek blijken natte natuurgebieden relatief veel wandelaars te trekken met de motieven Interesse en volledig Opgaan (Goossen et al., 2010).

Voor bedrijven die in natte natuurgebieden liggen en zich richten op recreanten met het motief Uitdaging, zouden investeringen minder rendement kunnen opleveren. Er is een (licht) negatieve relatie tussen dit landschapstype en dit motief en de omvang van dit motief neemt ook nog af.

De strijd om recreanten met het motief Gezelligheid kan voordelig zijn voor ondernemers die in de buurt liggen van waterrijke gebieden (zee, meren, rivieren) of recreatiegebieden. Investeringen werken in deze gebieden positief, maar dan wel in 'gezellige' elementen. Dat hoeft niet altijd natuur te zijn, maar kan ook een strandje, natuurboulevard of horeca zijn. Agrarische gebieden, bossen en in mindere mate parken zijn voor recreanten met het motief Gezelligheid niet gezellig genoeg en worden relatief minder gebruikt. Investeringen in deze gebieden moeten goed doordacht zijn, aangezien deze gebieden een negatieve relatie met dit motief hebben en de omvang van dit motief afneemt. Bosaanleg alleen is niet voldoende en wellicht is investeren in horeca in een bos een betere investering om een meer beleefbare natuur te krijgen.

Voor recreanten met het motief Tussen uit zijn investeringen van bedrijven die in parken liggen een goede zaak. Er is hiermee een positieve relatie en het motief neemt in omvang toe. Dit geldt ook voor de zee en grote meren. Investeringen van bedrijven in agrarische gebieden, bossen, recreatiegebieden en zee en grote meren loont ook voor die bedrijven die zich richten op recreanten met het motief Interesse. Investeringen van bedrijven die in gebieden met rivieren, kanalen en plassen liggen en die zich richten op recreanten met het motief Interesse, moeten zeer doordacht zijn, aangezien er een negatieve relatie bestaat tussen dit type landschap en motief. Bedrijven die zich richten op recreanten met het motief volledig Opgaan en in agrarische gebieden, recreatiegebieden en rivieren, kanalen en meren liggen, kunnen wellicht positieve rendementen van hun investeringen verwachten, want recreanten en/of toeristen die meer met dit motief gaan recreëren, gaan vaker naar deze gebieden. Omdat de omvang van dit motief gelijk blijft, kunnen investeringen van bedrijven die liggen in bossen, aan zee en grote meren minder succesvol zijn omdat een negatieve relatie bestaat tussen dit motief en het type landschap. 
Bij de strijd om de gunsten van recreanten met het motief Uitdaging zijn bedrijven die in bossen liggen in het voordeel bij investeringen en in mindere mate in het agrarisch gebied en droge natuurgebieden. Voor andere gebieden lijkt het moeilijker te zijn, aangezien er een negatieve relatie bestaat met dit motief en dit motief bovendien in omvang afneemt.

Uit het bovenstaande blijkt dat investeren door ondernemers die in een bepaald type natuur en landschap liggen, verschillend kan uitwerken voor een doelgroep. Opgemerkt moet worden dat de statistische relaties soms niet erg sterk zijn en dat recreanten met meer dan één motief recreëren. Nader onderzoek moet uitmaken welk deel van de omzet nu daadwerkelijk aan natuur en landschap kan worden toegerekend. Bij een positief resultaat zou dit de bereidwilligheid van ondernemers kunnen stimuleren.

Op basis van de resultaten uit het literatuuronderzoek kan een beeld geschetst worden naar de vraag naar donkergroene en lichtgroene natuur zoals in figuur 5.4 staat verbeeld. Daarbij is het voor het bedrijfsleven van belang om informatie te hebben over de omvang van het segment, zodat inschattingen kunnen worden gemaakt met betrekking tot rendementen.

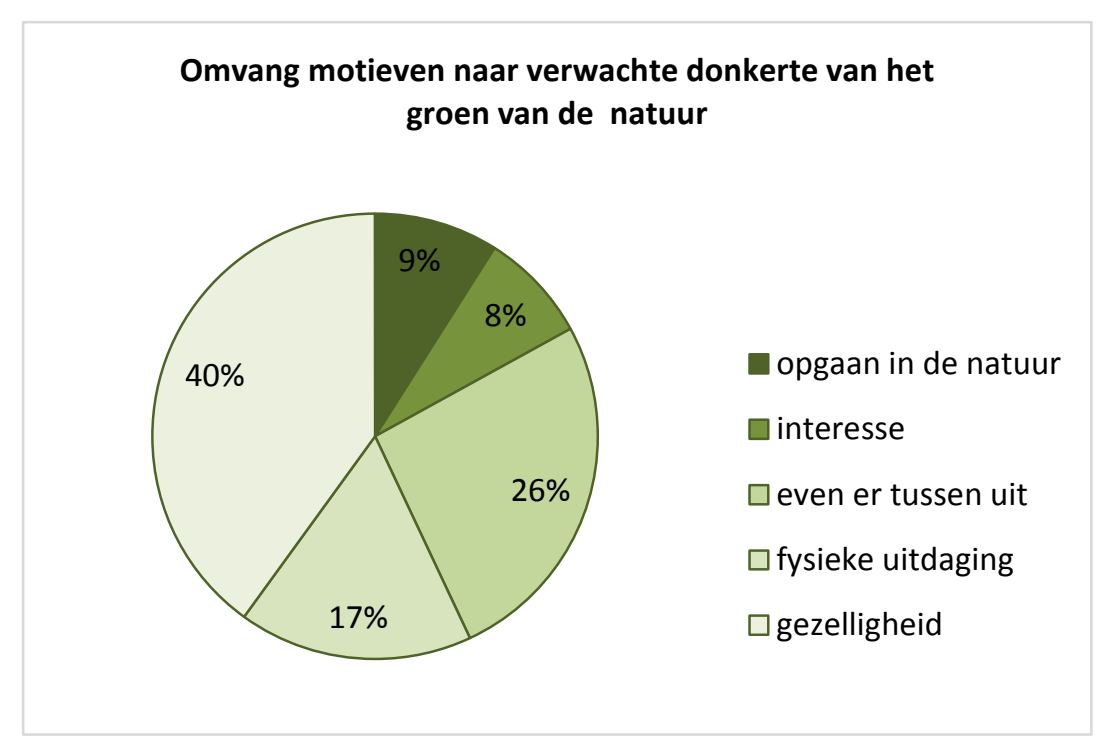

Figuur 5.4: Mate van donkerte van natuur in relatie tot omvang recreatiemotieven.

De vraag naar donkergroene natuur is beperkt tot een nichemarkt van een kleine tien procent. Met op maat gesneden acties kan dat nog enigszins oplopen, omdat ook de recreanten met het motief Interesse zich richting donkergroen kunnen begeven. Deze recreanten zijn nog met kennis en informatie enthousiast te krijgen over natuurdoelsoorten en habitattypen. De kloof zal naar verwachting vooral tussen recreanten met het motief Interesse en Even tussen uit zitten. Deze laatste zal veel meer met emotionele argumenten aangesproken moeten worden naast enkele meer rationele. Naarmate men meer recreanten met het motief Gezelligheid wil bereiken, zal er meer met emotionele argumenten moeten worden gewerkt. Zo heeft Knegtering (2002) bijvoorbeeld onderzocht hoe het belang van soortenbescherming afhangt van grootte en taxonomie. Natuurdoelsoorten moeten dan meer beschreven worden op basis van kenmerken als aaibaarheid, schoonheid, grootte, kleurenpracht en opvallendheid zoals zang, baltsen en burlen. Een voorbeeld hiervan is het jaarlijks terugkerende evenement op de Veluwe met burlende edelherten met hele shows en competities, dat vermarkt wordt c.q. kan worden.

Niemand weet waartoe de ingezette decentralisatie uiteindelijk zal leiden. De commissie Van Vollenhoven $(2015)^{37}$ constateert dat daarmee in elk geval het behartigen van donkergroene en lichtgroene belangen dooreen gaat lopen bij de uitvoering van het natuurbeleid. Omdat het budget voor het natuurbeleid niet toereikend lijkt te zijn voor alle opgaven, ontstaat het risico dat de

\footnotetext{
${ }^{37}$ Commissie Van Vollenhoven, 2015, Monumenten: Inspiratiebron voor de natuur!
} 
nationale belangen (en dus de donkergroene natuur) onder druk komen te staan, ten gunste van provinciale en gemeentelijke belangen die waarschijnlijk naar een lichtere kleur van groen neigen. De Rijksoverheid moet zich realiseren dat voor de financiering van het ontwikkelen en beheer van donkergroene natuur waarschijnlijk maar een handvol passionele ondernemers en consumenten zijn en dat het merendeel in het ontwikkelen en beheren van lichtgroen natuur zal gaan. In hoeverre de doelen van de Rijksoverheid dan gehaald worden is de vraag.

De donkergroene natuur, gericht op doelsoorten en habitats wordt veelal verzorgd door mensen met een passie voor natuur, al dan niet experts. Deze groep kan gezien worden als de innovators, de koplopers. Met hulp kunnen de early adopters volgen ofwel recreanten met het motief Interesse. De early majority volgen op de early adopters en indien in deze fase is aangeland, kan gesproken worden van mainstream. De verwachting is dat deze early majority eerder geneigd zijn naar lichtgroene natuur.

\section{$5.8 \quad$ Conclusies}

Ondernemers die zich willen richten op het ontwikkelen van producten en diensten voor de donkergroene markt, zullen rekening moeten houden met een verwachte markt van een beperkte omvang van circa $10 \%$.

De markt voor donkergroene natuur kan groeien wanneer er een op maat gemaakt aanbod komt met de juiste promotie- en communicatiemiddelen waarbij, afhankelijk van de doelgroep ingezet moet worden op kennis en informatie dan wel op emotie.

Om de vraag naar donkergroene natuur te stimuleren kan bij de natuurdoelsoorten een onderscheid gemaakt worden naar de 'recreatiewaarde' bestaande uit de belevingswaarde (of esthetische waarde) van de natuurdoelsoorten en de waarnemingskans. Bij de belevingswaarde moet dan vooral gelet worden op visuele en emotionele aspecten zoals de aaibaarheidsfactor, de grootte van de doelsoort, mate van opvallendheid (kleur, geur, gelijktijdig voorkomen (kuddes, velden van...)). Ook moet er een kans zijn om de doelsoort te kunnen aanschouwen. Doelsoorten die alleen 's nachts actief zijn hebben dan een lagere recreatiewaarde. Staatsbosbeheer is al aan het experimenteren met de recreatiewaarde van natuurdoelsoorten door in te zetten op de 'big five' van de Nederlandse natuur.

Voor natuurdoelsoorten met een lagere recreatiewaarde zal waarschijnlijk geen 'mainstreammarkt' voor aanwezig zijn. Het beschermen en ontwikkelen van deze soorten blijft dan vooral een overheidsverantwoordelijkheid, eventueel aangevuld met de nichemarkt van donkergroene consumenten.

Gezien de combinaties van waarden en normen die mensen hebben in tijd en plaats bij de beleving van natuur, zal er eerder sprake zijn van een continuüm in donkerte van natuur. De Rijksoverheid moet zich realiseren dat voor de financiering van het ontwikkelen en beheer van donkergroene natuur waarschijnlijk maar een handvol passionele ondernemers en consumenten zijn en dat het merendeel in het ontwikkelen en beheren van lichtgroen natuur zal gaan. In hoeverre de doelen van de Rijksoverheid dan gehaald worden is de vraag. 



\section{Samenvatting en discussie}

\subsection{Samenvatting}

Het streefbeeld beschreven in de Rijksnatuurvisie is ambitieus: een natuurinclusieve economie. Daarbij zijn de verwachtingen hooggespannen voor het natuurinclusief handelen door ondernemers. Van ondernemers wordt namelijk een centrale rol verwacht bij het behoud van natuur. Maar zijn die verwachtingen reëel?

\section{Lessen uit hoofdstuk 1}

In hoofdstuk 1 beschrijven we drie denkrichtingen om de mogelijkheden en de haalbaarheid van natuurinclusief ondernemen te analyseren.

- Denkrichting 1: Natuur en ondernemen is een onmogelijke combinatie. Vanuit de neo-klassieke economische theorie kan beredeneerd worden dat natuur een publiek goed is en dat daarom niet verwacht mag worden dat ondernemers hier zorg voor dragen. De praktijk bewijst echter het tegendeel, en laat zien dat er wel degelijk bedrijven zijn die investeren in natuur. Daarom gaan we verder met twee andere denkrichtingen.

- Denkrichting 2: Er vindt een transitie plaats naar een natuurinclusieve maatschappij. Dit betekent dat het de algemeen geldende norm wordt om 'behoud van natuur' als integraal onderdeel van de bedrijfsvoering mee te nemen.

- Denkrichting 3: Natuurinclusief ondernemen is en blijft een marketingstrategie, en daarom een specifiek segment in de markt naast andere segmenten, zoals goedkoop, luxe of gemak. Dit betekent dat sommige bedrijven ervoor kiezen om 'behoud van natuur' mee te nemen in hun bedrijfsvoering, en dit ook te communiceren naar hun klanten. Maar natuurinclusief ondernemen zal nooit mainstream worden.

\section{Lessen uit hoofdstuk 2}

Vanuit de marketingtheorie wordt consumentengedrag geanalyseerd. Consumenten zijn er in vele soorten en maten. De consumentenmarkt is gefragmenteerd (veel uiteenlopende voorkeuren), en is tevens erg hybride (consumenten handelen niet consequent; zijn vaak niet in één hokje te vangen). Hoe we handelen op de consumentenmarkt is sterk afhankelijk van de omgeving: wat dient zich aan, wat verwachten anderen van ons, etc. Daarom kan 'nudging' werken: overheidsduwtjes in de 'gewenste' richting, gebaseerd op inzichten uit de psychologie en gedragseconomie, met als doel om door subtiele aanwijzingen of informatieverstrekking een gedragsverandering teweeg te brengen. Het marktsegment 'natuurinclusief' kan zodoende vergroot worden, maar het blijft een marktsegment naast andere segmenten.

Startpunt van de transitietheorie is om met welwillenden coalities te vormen en aan de slag te gaan met experimenten, waarbij een leerproces wordt doorlopen. Dit leidt - zo is tenminste de gedachte tot initiatieven die opvolging krijgen. Op een gegeven moment zijn er zoveel initiatieven dat een takeoff fase wordt bereikt en een doorbraak gerealiseerd kan worden. Dat leidt tot een nieuw paradigma: een nieuwe kijk op de wereld die mettertijd standaard wordt. Maar, er is ook weerstand tegen een dergelijke paradigmaverandering. Het nieuwe paradigma is in dit geval: natuurinclusief ondernemen is de enige juiste wijze van ondernemen.

\section{Lessen uit hoofdstuk 3}

Particulier initiatief als het gaat om natuurbeheer is niet nieuw. Maar de nieuwe visie op natuurbeheer heeft wel vergaande gevolgen voor bevoegdheden van vooral provincies en particulieren partijen in het beheer en voor de financiering ervan. We zien dat het particulier initiatief verschillende vormen kent, met of zonder financiële steun van de overheid. De overheid heeft verschillende instrumenten ontwikkeld om particuliere initiatieven te faciliteren. Welke rol de overheid zelf vervult, is een politieke beslissing. De kernvraag die achter dit besluit ligt, is of de maatschappij een natuurbeleid wenst waarbij de overheid op afstand staat, en waarbij andere partijen de vrijgekomen ruimte opvullen, of juist 
een natuurbeleid vormgegeven en ingevuld door een sterke overheid met een missie (Mazzucato, 2015 en Rifkin, 2014).

De overheid heeft verschillende taken. Traditioneel is de taak vooral sturend, al dan niet via wetgeving. De laatste jaren is daarbij veel aandacht gekomen voor faciliteren en netwerken voor maatschappelijke initiatieven. Daarbij is het de vraag in hoeverre een masterplan voor natuurbehoud, inclusief budget, nodig is om ambities werkelijk waar te maken.

\section{Lessen uit hoofdstuk 4}

We hebben gekeken naar enkele grondgebonden sectoren, met een directe band met natuur. De onderzochte sectoren zijn: de biologische landbouw, de recreatiesector en particulier landgoedbezit. De biologische landbouw is een nichemarkt gebleven, maar groeit de laatste jaren wel. In totaal blijft het areaal biologische landbouw in Nederland echter onder de 5\%. Over het algemeen wordt gesteld dat biologische landbouw, in vergelijking met gangbare landbouw, beter is voor natuur en milieu. Ook doen biologische boeren in verhouding meer aan verbrede landbouw, waaronder agrarisch natuurbeheer. In de recreatiesector is de laatste jaren meer aandacht voor het verbinden van recreatie met natuur. Hierbij stelt men zich ten doel om economische groei en natuur samen te laten gaan, waarbij natuur en landschap steeds vaker door de recreatieondernemer worden gezien als drager van zijn (of haar) bedrijfsvoering. En hoewel de recreatieve consument over het algemeen steeds meer luxe wil, zitten natuurkampeerterreinen (met minimale voorzieningen) en kamperen bij de boer wel in de lift. Het traditionele verdienmodel voor particulier landgoedbezit was houtproductie, landbouw en jacht. Natuurbeheer kan, voor sommige landgoederen, een (aanvullend) verdienmodel zijn, maar wel eentje die sterk afhankelijk is van overheidsbijdragen.

De belangenorganisaties voor de biologische landbouw, recreatiesector en particulier landgoedbezit (Bionext, Recron en FPG) staan positief tegenover de Rijksnatuurvisie en het idee van 'natuurinclusief' ondernemen. Zij zien kansen voor ondernemers. Maar alle drie belangenorganisaties wijzen erop dat de regelgeving achter blijft op het visiedocument. Bionext noemt verschillende voorbeelden van recente wetswijzigingen die zelfs een averechts effect hebben gehad op natuurinclusief ondernemen door biologische boeren. En door de decentralisatie van natuurbeleid is de bureaucratie toegenomen, aldus FPG. RECRON stelt dat door starre regelgeving ondernemers huiverig zijn om grond in te zetten voor tijdelijke natuur, uit angst zichzelf op slot te zetten.

\section{Lessen uit hoofdstuk $\mathbf{5}$}

De mogelijkheden voor natuurinclusief ondernemen binnen de recreatiesector worden in dit hoofdstuk verder uitgewerkt. Daarbij wordt met name gekeken naar de mogelijkheden tot opschaling: natuurinclusief ondernemen is nu nog iets voor koplopers, maar hoe groot is de kans dat zij hierin gevolgd worden door een grote groep ondernemers zodat natuurinclusief ondernemen mainstream wordt. Daarbij wordt ingezoomd op verschillende typen consumenten, en vandaaruit wordt de belangstelling voor groene recreatie, nu en in de toekomst, geschat. De vraag naar donkergroene recreatie, dat wil zeggen recreatie waarbij natuur centraal staat, wordt op een kleine $10 \%$ geschat, maar verwacht wordt dat deze verder kan groeien door de recreatieve waarde van natuur te benadrukken. Zo probeert Staatsbosbeheer recreatie te koppelen aan het ervaren en beleven van reeën, wilde zwijnen, bevers, edelherten en zeehonden. Dit creëert tegelijkertijd draagvlak voor het in stand houden en beschermen van deze donkergroene natuur. De conclusie is dat groene recreatie groeimogelijkheden heeft, maar toch een nichemarkt blijft.

\subsection{Discussielijnen}

Bovenstaande lessen brengt ons tot drie discussielijnen. Deze discussielijnen beschrijven verschillende ontwikkelingen die wij signaleren, zonder daar vergaande conclusies uit te willen trekken. De ontwikkelingen hebben betrekking op:

1) visies op de relatie natuur en ondernemen,

2) de realiteit voor natuur en ondernemen, en

3) de rol van de overheid voor natuur en ondernemen. 


\section{Discussielijn 1: Marketingtheorie en transitietheorie}

Binnen de marketingtheorie worden begrippen als nichemarkt en mainstreaming gehanteerd. Het gaat om een product of een productgroep dat ingang vindt bij een kleine groep (niche) dan wel een grote groep consumenten (mainstream). Vanuit de marketingtheorie is 'donkergroen' een nichemarkt. Maar 'lichtgroen', dat wil zeggen natuur als decor, spreekt veel consumenten aan en kan daarom mainstream worden. 'Licht groen' kan ook gemakkelijk gecombineerd worden met andere marktsegmenten als luxe of gezellig.

De transitietheorie omhelst een geheel nieuwe kijk op de wereld, met begrippen als: paradigma shift, nieuwe economie, en systeeminnovatie. Het gaat om een geheel nieuwe manier van consumerenproduceren-samenleven. De transitietheorie stelt dat de maatschappij onherroepelijk zal veranderen en daar hoort ook een nieuwe relatie tot groen bij. Alleen bedrijven die op tijd omschakelen naar groen zullen het redden op termijn, de achterblijvers zullen uiteindelijk moeten afhaken. Het gaat dan niet om lichtgroen of donkergroen maar om groen als bestaansvoorwaarde voor de mens, dat wil zeggen: wij mensen zijn afhankelijk van natuur.

Hierboven hebben we marketingtheorie en transitietheorie als afzonderlijke theorieën besproken. Dat neemt niet weg dat de twee ook aan elkaar gekoppeld kunnen worden. Want vanuit een nichemarkt kun je ook komen tot een transitie. Biologische landbouw is een nichemarkt, bijvoorbeeld. Maar wanneer nieuwe verbindingen ontstaan tussen biologische landbouw en de maatschappij kan er een systeeminnovatie ontstaan, met nieuwe relaties tussen consument en producent, of met nieuwe plantdiercombinaties waardoor een landbouwsysteem ontstaat die past in een circulaire economie. Hierbij rijst de fundamentele vraag die kan leiden tot een paradigmaverandering, namelijk hoe we ons verhouden tot ons voedsel en tot onze omgeving.

\section{Discussielijn 2: Naast vergroening ook steeds meer discounters}

Het idee achter de Rijksnatuurvisie is ruimte creëren voor particulier initiatief. Dit heeft geleid tot mooie voorbeelden van particuliere bijdragen aan de groene leefomgeving. Er is daadwerkelijk een verandering gaande: steeds meer ondernemers nemen hun verantwoordelijkheid en streven naar een natuurvriendelijkere wijze van produceren (zie Kamerbeek, 2012; Wilschut en Koedoot, 2014; Breman et al., 2014; Fontein et al., 2015; en Kamerbeek, 2015).

Tegelijkertijd zien we een opkomst van discounters, prijsvechters en bedrijven die inspelen op gemakzoekers (bijv. Just Eat). Want naast groen en duurzaam blijft er vraag naar goedkoop en gemakkelijk, en zijn er bedrijven die daar op inspelen. In de alledaagse praktijk blijkt er een grote groep mensen die de ene dag iets koopt op een biologische streekmarkt (want het ziet er zo lekker uit), en de volgende dag een pizza thuis laten bezorgen (want dat is zo gemakkelijk). Juist deze 'hybride' groep kan een duwtje in de gewenste richting (nudge) gebruiken.

In de Rijksnatuurvisie wordt beschreven hoe belangrijk het is dat vanuit de maatschappij - door burgers, bedrijven en buitenlui - verantwoordelijkheid wordt genomen voor behoud van natuur. Een dergelijke omslag in beleid werd niet alleen ingegeven door de wens tot dan wel noodzaak van een andere, meer eigentijdse rol voor de overheid, maar ook door bezuinigingen op het natuurbudget. Niet alles wil en kan simpelweg meer vanuit Den Haag geregeld worden.

Kortom: er zijn mooie particuliere initiatieven met groen, ook van bedrijven die duurzaam produceren en streven naar het behoud van de leefomgeving. Maar tegelijkertijd zijn er ook producenten die minder oog hebben groen en duurzaam, en tegen zo laag mogelijke kosten willen blijven produceren wetende dat hier ook volop vraag naar is. De hedendaagse consument is wispelturig, en switcht makkelijk tussen voorkeuren. Naast een beperkte groep 'consequent groene consumenten', zijn er veel consumenten die slechts een deel van de tijd voor groen kiezen. Daardoor bestaat het risico dat groen een 'niche' blijft, en de mainstreaming van natuurinclusief ondernemen niet vanzelf tot stand komt. 
Discussielijn 3: Visie overheid ten opzichte van wetgeving vanuit diezelfde overheid

Zowel Bionext, FPG als RECRON zijn positief over de Rijksnatuurvisie en het idee van natuurinclusief ondernemen. Bionext is bezig ideeën te ontwikkelingen voor boeren die bovenwettelijke taken voor natuur willen uitvoeren, en dat willen vermarkten. FPG ziet mogelijkheden voor nieuwe verdienmodellen voor landgoedeigenaren die meer aan natuurbeheer willen doen. RECRON heeft meegewerkt aan een visiedocument voor de gastvrijheidseconomie met daarin als belangrijk actiepunt het verbeteren van de relatie tussen recreatie en natuur. Kortom, in de verschillende sectoren ziet men mogelijkheden voor ondernemen met groen.

Alle drie de belangenorganisaties merken op dat de wet- en regelgeving nog ver achter loopt op de toekomstbeelden van het kabinet, zoals beschreven in de Rijksnatuurvisie. Opgemerkt wordt dat het vertrouwen in particulieren wat betreft natuurbeheer nog beperkt is. "Dan wil men alles toch weer dichttimmeren met wetgeving..." Er wordt zelfs opgemerkt dat recente wetgeving ${ }^{38}$ averechtse effecten heeft gehad op de mogelijkheden om 'natuurinclusief' te ondernemen. Er zijn echter wel mogelijkheden voor de overheid om natuurinclusief ondernemen te stimuleren. Bionext wijst op mogelijkheden via het ruimtelijk ordeningsbeleid, waarbinnen extra eisen gesteld kunnen worden aan pachters in de buurt van natuurgebieden, zoals meer natuurrealisatie en minder landbouwproductie. Met name biologische boeren kunnen hier goed aan voldoen. FPG stelt dat wanneer (natuur)terreinen en -gronden op 'de markt' komen, bijvoorbeeld omdat Staatsbosbeheer deze afstoot, een openbare en transparante aanbesteding van belang is. Dan maken particulieren meer kans om deze gronden te verwerven en in te richten voor particulier natuurbeheer. RECRON denkt aan exclusief overnachten in de natuur, waarbij de recreatieondernemer bijdraagt aan het onderhoud van de natuur in en om zijn bedrijf. Maar overnachten in de natuur moet dan wel wettelijk mogelijk worden.

\subsection{Ter afsluiting}

In 2016 wordt dit onderzoek vervolgd. We richten ons dan met name op wat daadwerkelijk nodig is om groene ondernemerschap in de praktijk te laten plaatsvinden. Welke maatregelen, interventies, instrumenten werken wel, en welke werken niet? En wat is de reden hiervoor? Het onderzoek gaat daarmee dieper in op de daadwerkelijke realisatie van het groen ondernemerschap, en zorgt voor concretisering van de visie in uitvoerbare handelingsopties.

\footnotetext{
${ }^{38}$ Genoemd is de afschaffing van de melkquota, wat heeft geleid tot intensivering. Daarnaast is genoemd het afschaffen van omschakelsubsidies voor gangbare boeren die de overstap maken naar biologisch.
} 


\section{Literatuur}

Bakker, E. de \& H. Dagevos (2010). Vleesminnaars, vleesminderaars en vleesmijders; Duurzame eiwitconsumptie in een carnivore eetcultuur, Den Haag, LEI Wageningen UR. LEI Rapport. Onderzoeksveld Consument \& Gedrag 2010-003.

Bauman W. (2002). In de ban van de Duivelsberg. Scriptie Sociaal-ruimtelijke Analyse. Wageningen Universiteit, Wageningen.

Boer, T.A. de, A.T. de Blaeij, B.H.M Elands, H.C.M. de Bakker, C.S.A. van Koppen en A.E. Buijs (2014). Maatschappelijk draagvlak voor natuur en natuurbeleid in 2013. Wageningen, Wettelijke Onderzoekstaken Natuur \& Milieu, Wageningen UR. WOt-rapport 126.

Bont, de R. en A. Prins (2014). Het Landgoedbedrijf krijgt vervolg bij de FPG. De Landeigenaar, No. 6. December 2014.

Bouwma, I [M.], [C.] M. Goossen, T. [A.] de Boer, R. [J.H.G.] Henkens, F. Langers \& D.J. van der Hoek (2014). Recreatie en natuurlijk kapitaal. Blz. 96-108. In: Natuurlijk kapitaal, toestand, trends en perspectief (ed. Joep Dirkx), Planbureau voor de Leefomgeving, Den Haag.

Breman, B., E. de Lijster, D. Kamphorst, N. de Sena (2014). Betrokkenheid van bedrijven bij natuur in Nederland. Wageningen, Wettelijke Onderzoekstaken Natuur \& Milieu, Wageningen UR. WOt-paper 36.

Buijs, A. (2009). Natuurbeelden. Publieke visies op natuur en de consequenties voor het natuurbeheer. Samenvatting PhD Thesis, Wageningen Universiteit.

CBS, PBL, Wageningen UR (2015). Biologische landbouw: aantal bedrijven en areaal, 1998-2014 (indicator 0011, versie 14, 21 mei 2015). www.compendiumvoordeleefomgeving.nl. CBS, Den Haag; Planbureau voor de Leefomgeving, Den Haag/Bilthoven en Wageningen UR, Wageningen.

Commissie van Vollenhoven (2015). Monumenten: Inspiratiebron voor natuur!, oktober 2015.

Dagevos, H. en E. de Bakker (2008). Consumptie verplicht : een kleine sociologie van consumeren tussen vreten en geweten. Den Haag, LEI Wageningen UR. Rapport / LEI Werkveld 3, Consumenten en ketens 2008-013.

Dirkx, J. \& B. de Knegt (2014). Natuurlijk kapitaal als nieuw beleidsconcept. Balans van de Leefomgeving 2014 - deel 7, Den Haag: Planbureau voor de Leefomgeving.

Donders, J.L.M. \& C.M. Goossen (2012). Recreatie in groenblauwe gebieden. Analyse data Continu Vrijetijdsonderzoek: bezoek, leeftijd, stedelijkheidsgraad en activiteiten van recreanten. Wageningen, Wettelijke Onderzoekstaken Natuur \& Milieu, Wageningen UR. WOt-werkdocument 303.

Donders, J., J. Luttik, M. Goossen, F. Veeneklaas, J. Vreke \& T. Weijschede (2011). Waar gaat dat heen? Recreatiemotieven, landschapskwaliteit en de oudere wandelaar. Achtergronddocument bij Natuurverkenning 2011. Wageningen, Wettelijke Onderzoekstaken Natuur \& Milieu, Wageningen UR. WOt-werkdocument 271.

Douglas, M. (1996). Thought styles: Critical Essays on Good Taste. London: Sage.

Elands, B.H.M. \& J. Lengkeek (2000). Typical Tourists: Research into the theoretical and methodological foundations of a typology of tourism and recreation experiences. Wageningen, the Netherlands: Mansholt Graduate School.

Erisman, J.W., N. van Eekeren, W. Cuijpers, J. de Wit, Eindredactie: L. Daniëls (2014). Biodiversiteit in de melkveehouderij - Investeren in veerkracht en reduceren van risico's, Louis Bolk Instituut, Zeist. Publ. nr.: 2014-042-LbD.

EZ (2013). Kennisprogramma DuurzaamDoor: sociale innovatie voor een groene economie 2013-2016. Ministerie van Economische Zaken, Den Haag.

EZ (2014). Rijksnatuurvisie - Natuurlijk verder, Ministerie van Economische Zaken, Den Haag, 23 april 2014.

Fontein, R.J., R. Michels, V. Linderhof, M. Goossen \& R. de Graaff (2015). De potentie van natuurcombinaties; Inzicht en reflecties op de meerwaarde van een nieuw concept. Wageningen, Alterra Wageningen UR. Alterra-rapport 2648. 
Goossen, C.M. (2009). Monitoring recreatiegedrag van Nederlanders in landelijke gebieden. Jaar 2006/2007. Wageningen, Wettelijke Onderzoekstaken Natuur en Milieu, Wageningen UR. WOt-werkdocument 146.

Goossen, C.M. (2013). Nieuwe natuurvisie van de Rijksoverheid. Groen : vakblad voor groen in stad en landschap 70 (2013)2. - ISSN 0166-3534 - p. 37 - 40.

Goossen, C.M. \& T.A. de Boer (2008). Recreatiemotieven en belevingssferen in een recreatief landschap; Literatuuronderzoek. Wageningen, Alterra Wageningen UR. Alterra-rapport 1692.

Goossen, C.M. R.J.H.G. Henkens, I. Woltjer (2010). Ontwikkeling behoefte aan recreatie-activiteiten en relatie met motieven; Analyse vrijetijdsgegevens voor een herijking van recreatietekorten. Wageningen, Alterra Wageningen UR. Alterra-rapport 2034.

Goossen C.M., F. Langers \& T.A. de Boer (2013). Relaties tussen recreanten, ondernemers en landschap. Wageningen, Wettelijke Onderzoekstaken Natuur \& Milieu, Wageningen UR. WOt-werkdocument 329.

Groene Zaak, De et al. (2015). Manifest 'More prosperity, new jobs', manifesto on Circular Economy Policy in the EU.

Hajer, M. (2011). De energieke samenleving. Op zoek naar een sturingsfilosofie voor een schone economie. Den Haag, Planbureau voor de Leefomgeving.

Heberlein, T. (2012). Navigating Environmental Attitudes. Oxford: Oxford University Press.

Kamerbeek, H. (2012). Waardevol Groen. Uitgave van Innovatie Netwerk, Den Haag.

Kamerbeek, H. (2015). Ondernemen met natuur - Tips voor Grondeigenaren. Uitgave in samenwerking met de Federatie particulier Grondbezit (FPG), Utrecht.

Kamphorst, D.A., T.A. Selnes \& W. Nieuwenhuizen (2015). Vermaatschappelijking van natuurbeleid; Een verkennend onderzoek bij drie provincies. Wageningen, WOT Natuur \& Milieu, Wageningen UR. WOttechnical report 42.

Klijn, J. (2011). Wisselend tij. Omgang met en beleid voor natuur en landschap in verleden en heden; Achtergronddocument bij Natuurverkenning 2011. Wageningen, WOT Natuur \& Milieu, Wageningen UR. WOt-werkdocument 239.

Knegtering, E., van der Windt, H. J. \& Uiterkamp, A. J. S. (2011). Public decisions on animal species: does body size matter?. Environmental Conservation, 38(01), 28-36.

Lewis, D. \& D. Bridger (2000, The soul of the new consumer: authenticity - what we buy and why in the new economy. Nicholas Brealey Publishing, London.

LNV (1992). Kiezen voor recreatie: beleidsnota openluchtrecreatie 1992-2010, resultaten van advisering en inspraak. Ministerie van Landbouw, Natuurbeheer en Visserij, Den Haag.

Loeber, A. en D.J. Joustra (2004). Transitie en systeem: de eenheid van verandering, Transitiepaper 5, NIDO.

Loorbach, D.A. en Rotmans, J. (2010). The practice of transition management: Examples and lessons from four distinct cases. Futures 42 (3), 237-246.

Luijk, H. van (2000). Een stap verder dan ethiek. In: H. Noordergraaf en J. van Workum (red.) Maatschappelijk verantwoord ondernemen. Een nieuwe fase in het kapitalisme. Kok, Kampen.

Mazzucato, M. (2013). The Entrepreneurial State: debunking public vs. private sector myths (Anthem 2013).

Mazzucato, M. (2015). Mission-Oriented Finance for Innovation (http://missionorientedfinance.com).

Meeusen, M.J.G., Koopmans, C., Stortelder, A.H.F., Zaalmink, W., Prins, H., Onwezen, M.C., Ham, A. van den \& Wagenaar, J.P. (2015) Natuur en biodiversiteit in de biologische markt. Verkenning van de mogelijkheden om natuur en biodiversiteit in de biologische markt te verwaarden. Den Haag, LEI Wageningen UR. Report / LEI 2015-011.

MNP, CPB \& RPB (2006). Welvaart en leefomgeving, een scenariostudie voor Nederland in 2040, hoofdstuk 9: Recreatie. Rapport 500082001. RIVM, Bilthoven.

Moore, G. A. (1995). 'Crossing the Chasm', HarperCollins Publishers.

NRITmedia/NBTC/CELTH (2014). Trendrapport toerisme, recreatie en vrije tijd 2014. Nieuwegein/Den Haag/Breda.

Oostenbrugge, van R. (2011). Kijkrichtingen van de natuurverkenning. Landschap, 28 (4), pp. 160-161. 
PBL (2010). Wegen naar een nieuw natuurbeleid. Planbureau voor de Leefomgeving, Bilthoven.

PBL (2014). How sectors can contribute to sustainable use and conservation of biodiversity. CBD, Technical Series No 79, PBL Netherlands Environmental Assessment Agency, Bilthoven, Netherlands.

PBL \& NSOB (2014). Leren door doen: Overheidsparticipatie in de energieke samenleving. Planbureau voor de Leefomgeving / Nederlandse School voor Openbaar Bestuur, Den Haag.

Rabobank (2015). Cijfers \& Trends. Thema-update: Verblijfsrecreatie. Meer toerisme, maar grotere uitdagingen. Rabobank, Utrecht.

Raaij, W.F. van \& G. Antonides (1997) Consumentengedrag: een sociaal-wetenschappelijke benadering. Uitgeverij Lemma, Utrecht.

Rifkin, J. (2013). The Third industrial Revolution. How Lateral Power is Transforming Energy, the Economy, and the World. Palgrave MacMillan Trade.

Rifkin, J. (2014). The Zero Marginal Cost Society: The Internet of Things, the Collaborative Commons, and the Eclipse of Capitalism. Palgrave MacMillan Trade.

ROB (2012). Loslaten in vertrouwen. Naar een nieuwe verhouding tussen overheid, markt en samenleving. Raad voor het Openbaar Bestuur, Den Haag.

Rogers, E.M. (1962). 'Diffusion of Innovations', The Free Press.

Rotmans, J. (2003). Transitiemanagement: Sleutel voor een duurzame samenleving. Van Gorcum, Assen.

Rotmans, J., R. Kemp, M. van Asselt, F. Geels, G. Verbong \& K. Molendijk (2000). Transities \& transitiemanagement: De casus van een emissiearme energievoorziening. ICIS (International Centre for Integrative Studies), Maastricht.

Schuerhoff, M. \& A. Ruijs (2015). Hoe gaan bedrijven om met biodiversiteit - Leren van de Subsidieregeling Biodiversiteit en Bedrijfsleven. PBL, Bilthoven.

Schwartz, S. H. (1992). Universals in the content and structure of values: Theoretical advances and empirical tests in 20 countries. In M. Zanna (Ed.), Advances in experimental social psychology. Orlando, FL: Academic Press.

Selnes, T. en M. Aalders (2005). Een kantelende overheid. Debat intensieve veehouderij en de transitie naar duurzame landbouw. Den Haag, LEI Wageningen UR / Amsterdam, Centrum voor Milieurecht, UvA.

Selnes, T, D. Kamphorst, B. Arts, J. van Tatenhove (2014). Initiatieven in de energieke samenleving - op zoek naar vernieuwing in het groene domein. Wageningen, WOT Natuur \& Milieu Wageningen UR. WOtpaper 29.

Seyfang, G. (2007). Cultivating carrots and community: local organic food and sustainable consumption, in: Environmental Values 16, pp. 105-123.

Silvis, H.J. \& M.J. Voskuilen (2014). Bedrijfsuitkomsten in de Nederlandse particuliere bosbouw over 2012. LEI-rapport 2014-017. LEI Wageningen UR, Den Haag.

Smits, M.J.W., Heide, C.M. van der (2014). De rol van bedrijven bij behoud van ecosysteemdiensten, Wageningen, Wettelijke Onderzoekstaken Natuur \& Milieu, Wageningen UR. WOt-paper 31.

Smits, M.J.W., Heide, C.M. van der, Burg, S.W.K. van den, Meeusen, M.J.G. \& Voskuilen, M.J. (2013). Duurzaam gebruik van ecosysteemdiensten door private sectoren. Wageningen, Wettelijke Onderzoekstaken Natuur \& Milieu. WOt-werkdocument 342.

STIRR (2015). Natuurlijk verder ... met de gastvrijheidssector, SynergieProgramma 2015 - Natuur en Gastvrij Ondernemen, Den Haag.

Tonkens, E. H. \& I. Verhoeven (2011). Bewonersinitiatieven: proeftuin voor partnerschap tussen burgers en overheid. Een onderzoek naar bewonersinitiatieven in de Amsterdamse wijkaanpak. Universiteit van Amsterdam/AISSR.

Tonkens, E.H. \& M. de Wilde (2013). Als meedoen pijn doet: affectief burgerschap in de wijk. Amsterdam: Van Gennep.

Tonkens, E.H. en W.G.J. Duyvendak (2015). 'Graag meer empirische en minder eufore kijk op burgerinitiatieven', in: Sociale Vraagstukken www.socialevraagstukken.nl 
Vader, J., F.A. Geerling-Eiff, P. Schipper, S. Roemer, A. Hollemans \& B. Looman (2011). Meer nieuwe landgoederen? Hoe de overheid landgoedontwikkeling makkelijker kan maken. Den Haag, LEI Wageningen UR. LEI-rapport, 2011-082.

Vink, Jaffe (2015). De Vakantie. Trouw, 11-07-15.

Vijn, M. en M. Borgstein (2014). Nieuwe verdienmodellen op landgoederen met pachters. De Landeigenaar, No. 6. December 2014.

Vijn, M.P., M.H. Borgstein, F.A.N. van Alebeek \& G. Migchels (2015). Naar nieuwe verdienmodellen op een landgoed met pachters. PPO publicatienummer 630. PPO (Wageningen UR), Lelystad.

Wilschut, M. \& M. Koedoot (2014). Natuur en ondernemen. Publicatie VHL en Trouw.

WRR (2012). Vertrouwen in burgers. Den Haag, Wetenschappelijke Raad voor het Regeringsbeleid. WRRrapport nr. 88. 


\section{Verantwoording}

Dit project is intensief begeleid door Petra van Egmond (PBL) en Frank Veeneklaas (WOT Natuur \& Milieu). Waar nodig hebben we deskundigen binnen Wageningen UR gevraagd om een bijdrage te leveren, te weten: Hans Dagevos, Trond Selnes en Martin Goossen. We hebben een drietal interviews gehouden met vertegenwoordigers van de biologische landbouwsector, recreatiesector en landgoedeigenaren. De namen van de geïnterviewde personen, en hun organisatie, staan vermeld in het Woord vooraf.

In dit WOt-technical report zijn geen gegeneraliseerde uitspraken opgenomen die gebaseerd zijn op één of enkele casussen. 


\section{Verschenen documenten in de reeks Technical reports van de Wettelijke Onderzoekstaken Natuur}

\& Milieu vanaf 2014

WOt-technical reports zijn verkrijgbaar bij het secretariaat van Unit Wettelijke Onderzoekstaken Natuur \& Milieu te Wageningen. T 0317 - 4854 71; E info.wnm@wur.nl

WOt-technical reports zijn ook te downloaden via de website www.wageningenUR.nl/wotnatuurenmilieu

30

Hennekens, S.M, M. Boss en A.M. Schmidt (2014) Landelijke Vegetatie Databank; Technische documentatie

31 Bijlsma, R.J., A. van Kleunen \& R. Pouwels (2014). Structuur- en functiekenmerken van leefgebieden van Vogelrichtlijn- en Habitatrichtlijnsoorten; Een concept en bouwstenen om leefgebieden op landelijk niveau en gebiedsniveau te beoordelen

Commissie Deskundigen Meststoffenwet (2015). Nut en risico's van covergisting. Syntheserapport.

33 Bijlsma, R.J. \& J.A.M. Janssen (2014). Structuur en functie van habitattypen; Onderdeel van de documentatie van de Habitatrichtlijn artikel 17rapportage 2013

Fey F.E., N.M.J.A. Dankers, A. Meijboom, P.W. van Leeuwen, J. Cuperus, B.E. van der Weide, M. de Jong, E.M. Dijkman \& J.S.M. Cremer (2014). Ecologische ontwikkeling binnen een voor menselijke activiteiten gesloten gebied in de Nederlandse Waddenzee; Tussenrapportage achtste jaar na sluiting (najaar 2013).

Kuindersma, W., F.G. Boonstra, R.A. Arnouts, R. Folkert, R.J. Fontein, A. van Hinsberg \& D.A. Kamphorst (2015). Vernieuwingen in het provinciaal natuurbeleid; Vooronderzoek voor de evaluatie van het Natuurpact.

Berg van den, F., W.H.J. Beltman, P.I. Adriaanse, A de Jong \& J.A. te Roller (2015). SWASH Manual 5.3. User's Guide version 5

37 Brouwer, F.M., A.B. Smit \& R.W. Verburg (2015). Economische prikkels voor vergroening in de landbouw

Verburg, R.W., R. Michels, L.F. Puister (2015) Aanpassing Instrumentarium Kosten Natuurbeleid (IKN) aan de typologie van het Subsidiestelsel Natuur en Landschap (SNL)

39

Commissie Deskundigen Meststoffenwet (2015). Actualisering methodiek en protocol om de fosfaattoestand van de bodem vast te stellen

Gies, T.J.A., J. van Os, R.A. Smidt, H.S.D. Naeff \& E.C. Vos (2015). Geografisch Informatiesysteem Agrarische Bedrijven (GIAB); Gebruikershandleiding 2010.

Kramer, H., J. Clement (2015). Basiskaart Natuur 2013. Een landsdekkend basisbestand voor de terrestrische natuur in Nederland

42 Kamphorst, D.A., T.A. Selnes, W. Nieuwenhuizen (2015). Vermaatschappelijking van natuurbeleid. Een verkennend onderzoek bij drie provincies

43 Commissie Deskundige Meststoffenwet (2015). Advies 'Mestverwerkingspercentages 2016'

Meeuwsen, H.A.M. \& R. Jochem (2015). Openheid van het landschap; Berekeningen met het model ViewScape
Oenema (2015). Stikstof- en fosfaatexcretie van gangbaar en biologisch gehouden landbouwhuisdieren. Herziening excretieforfaits Meststoffenwet 2015

Bruggen, C. van, A. Bannink, C.M. Groenestein, J.F.M. Huijsmans, H.H. Luesink, S.M. van der Sluis, G.L. Velthof \& J. Vonk (2015). Emissies naar lucht uit de landbouw, 1990-2013. Berekeningen van ammoniak, stikstofoxide, lachgas, methaan en fijn stof met het model NEMA.

47 Boonstra, F.G. \& A.L. Gerritsen (2015). Systeemverantwoordelijkheid in het natuurbeleid; Input voor agendavorming van de Balans van de Leefomgeving 2014

48 Overbeek, M.M.M., M-J. Bogaardt \& J.C. Dagevos (2015). Intermediairs die bijdragen van burgers en bedrijven aan natuur en landschap mobiliseren.

Os, J. van, R.A.M. Schrijver \& M.E.A. Broekmeyer (2015). Kan het Natuurbeleid tegen een stootje? Enkele botsproeven van de herijkte Ecologische Hoofdstructuur.

50 Hennekens, S.M., J.M. Hendriks, W.A. Ozinga, J.H.J. Schaminée \& L. Santini (2015). BioScore 2 Plants \& Mammals. Background and pre-processing of distribution data

51 Koffijberg K., P. de Boer, F. Hustings, A. van Kleunen, K. Oosterbeek \& J.S.M. Cremer (2015). Broedsucces van kustbroedvogels in de Waddenzee in 2011-2013.

52 Arets, E.J.M.M., J.W.H van der Kolk, G.M. Hengeveld J.P. Lesschen, H. Kramer, P.J. Kuikman \& M.J. Schelhaas (2015). Greenhouse gas reporting of the LULUCF sector in the Netherlands. Methodological background.

54 Groenestein, K. \& J. Mosquera (2015). Evaluatie van methaanemissieberekeningen en -metingen in de veehouderij.

Schmidt, A.M. \& A.S. Adams (2015). Documentatie Habitatrichtlijn-rapportage artikel 17, 2007-2012

Schippers, P., A.M. Schmidt, A.L. van Kleunen \& L. van den Bremer (2015). Standard Data Form Natura 2000; bepaling van de belangrijkste drukfactoren in Natura 2000-gebieden.

Fey F.E., N.M.A.J. Dankers, A. Meijboom, C. Sonneveld, J.P. Verdaat, A.G. Bakker, E.M Dijkman \& J.S.M. Cremer (2015). Ontwikkeling van enkele mosselbanken in de Nederlandse Waddenzee, situatie 2014.

Blaeij, A.T. de, R. Michels, R.W. Verburg \& W.H.G.J. Hennen (2015). Recreatiemodule in Instrumentarium Kosten Natuurbeleid (IKN); Bepaling van de recreatiekosten

Bakker, E. de, H. Dagevos, R.J. Fontein \& H.J. Agricola (2015). De potentie van co-creatie voor natuurbeleid. Een conceptuele en empirische verkenning 
60 Bouwma, I.M., A.L. Gerritsen, D.A. Kamphorst \& F.H Kistenkas (2015). Policy instruments and modes of governance in environmental policies of the European Union; Past, present and future

61 F. van den Berg, A. Tiktak, J.J.T.I. Boesten \& A.M.A van der Linden (2016). PEARL model for pesticide behaviour and emissions in soil-plant systems; Description of the processes
62 Kuiters, A.T., G.A. de Groot, D.R. Lammertsma, H.A.H. Jansman \& J. Bovenschen (2016) Genetische monitoring van de Nederlandse otterpopulatie; Ontwikkeling van populatieomvang en genetische status 2014/2015

63 Smits, M.J.W. \& C.M. van der Heide, H. Dagevos, T. Selnes \& C.M. Goossen (2016). Natuurinclusief ondernemen: van koplopers naar mainstreaming? 



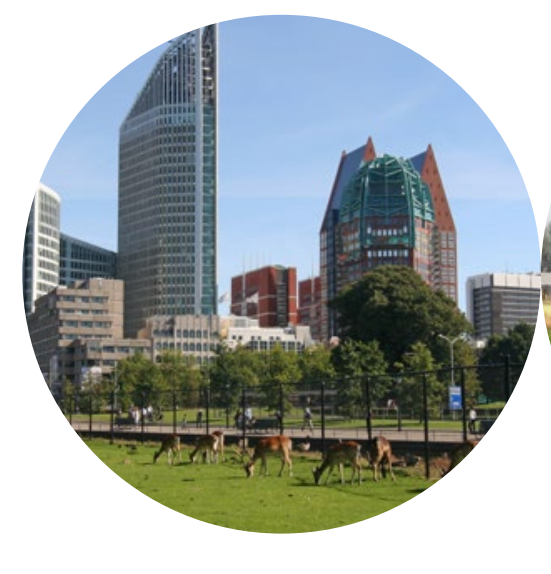

Thema Natuurverkenning

Wettelijke Onderzoekstaken Natuur \& Milieu

Postbus 47

6700 AA Wageningen

T (0317) 485471

E info.wnm@wur.nl

ISSN 2352-2739

www.wageningenUR.nl/ wotnatuurenmilieu

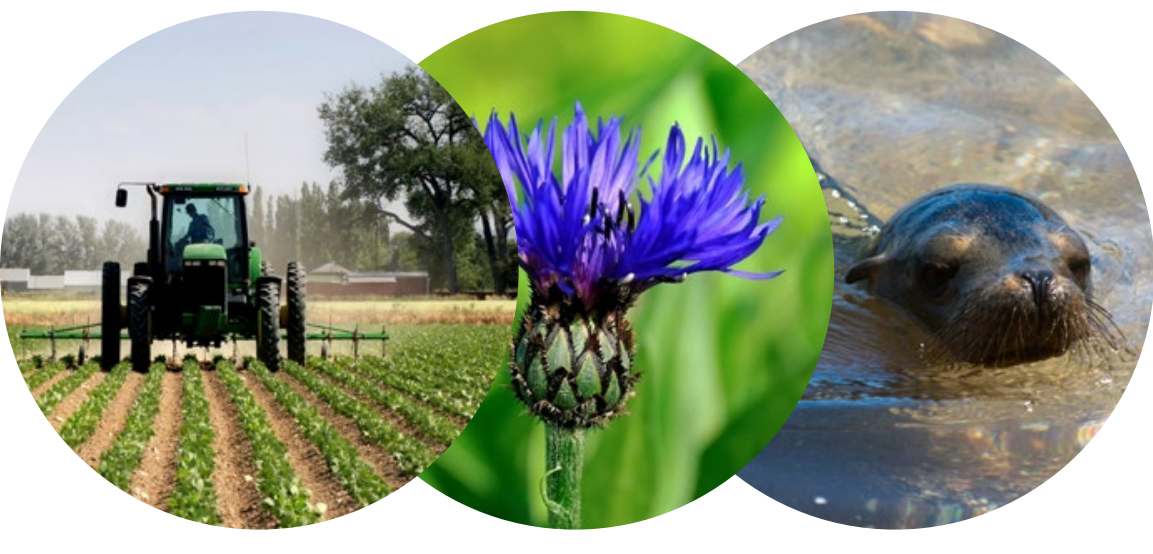

De WOT Natuur \& Milieu voert wettelijke onderzoekstaken uit op het beleidsterrein natuur en milieu. Deze taken worden uitgevoerd om een wettelijke verantwoordelijkheid van de minister van Economische Zaken te ondersteunen. De WOT Natuur \& Milieu werkt aan producten van het Planbureau voor de Leefomgeving, zoals de Balans van de Leefomgeving en de Natuurverkenning. Verder brengen we voor het ministerie van Economische Zaken adviezen uit over (toelating van) meststoffen en bestrijdingsmiddelen, en zorgen we voor informatie voor Europese rapportageverplichtingen over biodiversiteit.

De WOT Natuur \& Milieu is onderdeel van de internationale kennisorganisatie Wageningen UR (University \& Research centre). De missie is 'To explore the potential of nature to improve the quality of life'. Binnen Wageningen UR bundelen 9 gespecialiseerde onderzoeksinstituten van stichting DLO en Wageningen University hun krachten om bij te dragen aan de oplossing van belangrijke vragen in het domein van gezonde voeding en leefomgeving. Met ongeveer 30 vestigingen, 6.000 medewerkers en 9.000 studenten behoort Wageningen UR wereldwijd tot de aansprekende kennisinstellingen binnen haar domein. De integrale benadering van de vraagstukken en de samenwerking tussen verschillende disciplines vormen het hart van de unieke Wageningen aanpak. 